IZA DP No. 9183

The Return to Labor Market Mobility: An Evaluation of Relocation Assistance for the Unemployed

Marco Caliendo

Steffen Künn

Robert Mahlstedt

July 2015 


\title{
The Return to Labor Market Mobility: An Evaluation of Relocation Assistance for the Unemployed
}

\author{
Marco Caliendo \\ University of Potsdam, \\ DIW Berlin, IAB Nuremberg and IZA \\ Steffen Künn \\ $I Z A$ \\ Robert Mahlstedt \\ IZA and University of Potsdam
}

Discussion Paper No. 9183

July 2015

\author{
IZA \\ Germany
}

P.O. Box 7240

53072 Bonn

Phone: +49-228-3894-0

Fax: +49-228-3894-180

E-mail: iza@iza.org

Any opinions expressed here are those of the author(s) and not those of IZA. Research published in this series may include views on policy, but the institute itself takes no institutional policy positions. The IZA research network is committed to the IZA Guiding Principles of Research Integrity.

The Institute for the Study of Labor (IZA) in Bonn is a local and virtual international research center and a place of communication between science, politics and business. IZA is an independent nonprofit organization supported by Deutsche Post Foundation. The center is associated with the University of Bonn and offers a stimulating research environment through its international network, workshops and conferences, data service, project support, research visits and doctoral program. IZA engages in (i) original and internationally competitive research in all fields of labor economics, (ii) development of policy concepts, and (iii) dissemination of research results and concepts to the interested public.

IZA Discussion Papers often represent preliminary work and are circulated to encourage discussion. Citation of such a paper should account for its provisional character. A revised version may be available directly from the author. 


\section{ABSTRACT \\ The Return to Labor Market Mobility: An Evaluation of Relocation Assistance for the Unemployed}

In many European countries, labor markets are characterized by high regional disparities in terms of unemployment rates on the one hand and low geographical mobility among the unemployed on the other hand. This is somewhat surprising and raises the question of why only minor shares of unemployed job seekers relocate in order to find employment. The German active labor market policy offers a subsidy covering moving costs to incentivize unemployed job seekers to search/accept jobs in distant regions. Based on administrative data, this study provides the first empirical evidence on the impact of this subsidy on participants' prospective labor market outcomes. We use an instrumental variable approach to take endogenous selection based on observed and unobserved characteristics into account when estimating causal treatment effects. We find that unemployed job seekers who participate in the subsidy program and move to a distant region receive higher wages and find more stable jobs compared to non-participants. We show that the positive effects are (to a large extent) the consequence of a better job match due to the increased search radius of participants.

JEL Classification: J61, J64, J68, D04, C26

Keywords: evaluation, active labor market policy, labor market mobility, Instrumental variable approach

Corresponding author:

Steffen Künn

IZA - Institute for the Study of Labor

Schaumburg-Lippe-Str. 5-9

53113 Bonn

Germany

E-mail: kuenn@iza.org

\footnotetext{
*We thank Peter Kuhn, Fabrizia Mealli and participants at the 2013 Spring Meeting of Young Economists, the 2013 Annual Conference of the European Society for Population Economics (ESPE), the 2013 European Meeting of the Econometric Society (ESEM), the 2013 IZA Conference on Labor Market Policy Evaluation, the 2014 Meeting of the German Statistical Association, the 2015 SOLEEALE world meeting and seminars at IZA Bonn, University of Potsdam, Humboldt University Berlin and Georgetown University for helpful discussions and comments. We further thank the Research Data Center (FDZ) of the Federal Employment Agency at the Institute of Employment Research (IAB) for data access.
} 


\section{Introduction}

Many European countries are characterized by high regional disparities in terms of unemployment rates. For instance, the European Commission (Eurostat) reports regional unemployment rates for Germany (France) ranging from $2.7 \%$ to $10.8 \%(7.1 \%$ to $15.6 \%)$ in 2012, while the Southern European countries face even higher disparities ranging between $4.1 \%$ to $19.3 \%$ in Italy and $15.6 \%$ to $34.4 \%$ in Spain. Besides differences in real wages and labor productivity across regions, regional disparities in unemployment rates can be explained, in particular, by regional labor market tightness and a mismatch of vacancies and skills on a regional level (Taylor and Bradley, 1997; Giannetti, 2002). Although these regional disparities exist, geographical labor mobility in European countries is relatively low compared to the US, Canada or Australia (e.g. Puhani, 2001; Decressin and Fatás, 1995; Bentivogli and Pagano, 1999). ${ }^{1}$ This is somewhat surprising given that geographical labor mobility is considered to be an efficient adjustment to macroeconomic shocks (see Blanchard et al., 1992; Borjas, 2006, for evidence on the U.S.). Therefore, the question arises why European unemployed job seekers living in areas characterized by high unemployment rates do not move to more prosperous areas in order to find employment. Besides cultural reasons (preferences for certain regions, social environment, etc.), it is very likely that financial constraints prevent unemployed job seekers to search/accept distant jobs (see e.g. Ardington et al., 2009). In this context, a subsidy covering the moving costs might be a sensible strategy to incentivize unemployed job seekers to relocate to distant regions in order to find employment. In addition to individual labor market gains due to the relocation, such a program might also lead to an overall reduction in unemployment rates as increased geographical labor mobility might shift excess labor supply from depressed to prosperous regions. ${ }^{2}$

In Germany, one such active labor market policy (ALMP) provides unemployed job seekers a monetary subsidy covering the moving costs when starting a job in a distant region. ${ }^{3}$ However, it has not been examined as of yet whether the participation in the subsidy program and hence starting a new job in a distant region is a successful strategy for the unemployed. In this study, we contribute the first empirical evidence on the labor market return for participants in the

\footnotetext{
${ }^{1}$ Yearly mobility rates in the US $(\sim 3 \%)$ are approximately three times larger than the European average $(\sim 1 \%)$, while the southern European countries that were heavily affected by the recent economic crisis, e.g., Spain, Italy or Portugal, exhibit especially low mobility rates within the EU (e.g. Nickell, 1997; Bonin et al., 2008).

${ }^{2}$ For example, Marinescu and Rathelot (2013) estimate that the US unemployment rate could be reduced by up to $3 \%$ when reallocating job-seekers among regions, while Razin and Yuen (1997) show that labor mobility is an income-equalizing force, but policies to facilitate the movement of labor across different regions are needed to exploit these adjustment potentials.

${ }^{3} \mathrm{~A}$ distant region is defined as a location outside the daily commuting radius. With respect to the program under scrutiny, the daily commuting time between the current and the new location must exceed 2.5 hours (for both ways) in order to be eligible for the subsidy.
} 
program, i.e., we investigate the impact of participation in the subsidy program on prospective labor market outcomes such as wages, job stability and long-term employment probability. Germany is a good example to study such a policy as its labor market is characterized by high regional disparities in terms of unemployment rates and wage levels (e.g. Lehmer and Ludsteck, 2011) while the geographical mobility among unemployed workers was, until now, rather low. ${ }^{4}$ Given that the program has been successful, the policy might also be interesting for other countries characterized by similar labor markets suffering from low geographical mobility among the unemployed.

Following the model by Rogers (1997), which extends the classical job search model by Mortensen (1986) with respect to the search radius of job seekers, such a subsidy is expected to impact both the job search behavior and subsequent job characteristics of unemployed individuals. On the one hand, the subsidy would directly reduce moving costs, decreasing job seeker's reservation wage for distant jobs and hence increasing the search radius. On the other hand, the increase in the search radius will raise the job offer arrival rate, which is expected to raise reservation wages. It remains ambiguous which effect on the reservation wage dominates. Moreover, job seekers are expected to move - if at all — to regions which show the highest returns to their skills in terms of wages (Borjas et al., 1992) and employment probabilities (Arntz et al., 2011). ${ }^{5}$ This will most likely positively affect participants' labor market outcomes.

Based on a random sample of male entries into unemployment from 2005 and 2006 drawn from administrative data, we find that participants in the subsidy program predominately move to regions characterized by better economic conditions compared to their initial place of residence. Furthermore, descriptive statistics indicate improved labor market outcomes among participants, i.e., we find higher prospective employment probabilities, more stable jobs and higher wages than for non-participants. However, these gaps might be explained by structural differences between participants and non-participants and hence exist even in the absence of the treatment. Therefore, to identify causal treatment effects, we apply an instrumental variable approach allowing us to control for both observed and unobserved characteristics.

We exploit the intensity at which the local employment agencies (LEA) assign unemployed

\footnotetext{
${ }^{4}$ For instance, $68.5 \%$ of the prime-age population in Germany still lived in the same federal state in 2008 as where they grew up (Source: European Value Survey, own calculations). Moreover, Bonin et al. (2008) report that the share of the population that has moved their place of residence within Germany (compared to the year before) is relatively low and constant at about $1.3 \%$ within the period 1995-2006. Moreover, see, among others, Arntz (2005); Peukert and Smolny (2011); Lehmer and Ludsteck (2011) and Arntz et al. (2011) for the effects of geographical mobility on the German labor market in general, and Burda (1993); von Hagen (2000); Hunt (2006); Brücker and Trübswetter (2007) and Fuchs-Schündeln and Schündeln (2009) for the determinants and consequences of the East-West transition after the German reunification in 1990.

${ }^{5}$ In practice, these are expected to be areas characterized by better overall economic conditions compared to their current place of residence.
} 
job seekers to mobility programs as an instrumental variable. ${ }^{6}$ At the beginning of a calendar year, each LEA receives a fixed budget for ALMP programs from the Federal Employment Agency. While the set of programs is predetermined by the Federal Employment Agency, each LEA decides independently which share of the received budget to spend on which programs, i.e., the intensity at which it uses certain programs. The allocation of the budget, respectively the policy style, depends on (i) the local labor market conditions and (ii) the preferences of the LEA. ${ }^{7}$ We can eliminate the first part by controlling for detailed local labor market conditions (including regional fixed effects) so that our instrument represents the LEAs' preferences for mobility programs. Given that the job seeker has no influence on the allocation decision of the LEA, the instrument generates exogenous variation on the individual decision to participate in the treatment due to an information channel, i.e., a job seeker living in a district with a relatively high treatment intensity is, compared to a job seeker in a district with a low treatment intensity, more likely to receive knowledge about the existence of the program (as mentioned by the caseworker during regular talks), then to search for distant jobs, and finally participate in the subsidy program. The IV estimation results show that participants earn significantly higher wages and find more stable jobs compared to non-participants. We further show that the positive effects are driven by both the better economic conditions in the new region as well as upward job mobility.

The paper is structured as follows. The next section provides institutional details on the subsidy program and summarizes results of related studies. Section 3 describes the data, the definition of the estimation sample, the setting of the empirical analysis and presents descriptive statistics. Section 4 discusses the identification and estimation strategy, Section 5 presents the results, and Section 6 concludes.

\section{Institutional Settings and Related Literature}

\subsection{Mobility Assistance in Germany and the Program Under Scrutiny}

Programs designed to encourage the inter-regional labor mobility among unemployed job seekers were first introduced in Germany in 1998, whereby the use of these programs increased with the implementation of the "Hartz-Reform", a major labor market reform which was introduced between 2003 and 2005 (see, e.g., Caliendo and Hogenacker, 2012, for details). In their current

\footnotetext{
${ }^{6}$ In Germany, 178 LEA districts exist in total within our observation window.

${ }^{7}$ Among others, Fertig et al. (2006) and Blien et al. (2009) illustrate that, since a labor market reform in 1998, LEAs in Germany have a high degree of autonomy when allocating labor market policies, which results in substantial differences with respect to policy styles among regions.
} 
version, the mobility programs offer unemployed job seekers who are willing to move locally in order to find employment a wide range of support, starting from simple reimbursement of travel expenses for distant job interviews up to financial support for commuting costs or full coverage of transportation costs. ${ }^{8}$

In this study, we focus on one particular mobility program - the relocation assistance - as we are interested in the effect of taking up employment in a distant labor market (which requires relocation) on the labor market performance of job seekers. The relocation assistance program provides financial support for the costs associated with a permanent or temporary move to a distant region in order to find employment. In general, all unemployed job seekers who are not able to find a job locally but in a distant region are eligible to the program. Thereby, it is required that the daily commuting time from the current place of residence to the location of the new job would exceed 2.5 hours. ${ }^{9}$

If this pre-condition is fulfilled, the unemployed job seeker faces two options: (i) he/she can move permanently to the new location or (ii) leaves his/her current place of residence unchanged and just lives during the working week at the new location. The second option is called double housekeeping because it requires the job seeker to rent a second accommodation at the new location. The relocation assistance program provides a financial subsidy for both options. A temporary relocation is supported by a monthly payment for renting a secondary flat of up to $€ 260$ for a maximum of six months after the new job has been started. In case that the job seeker decides to move permanently to the new location, the program provides full coverage of the moving costs (with a maximum of $€ 4,500) .{ }^{10}$ The permanent relocation has to occur within a time window of two years after the new distant job has been started. The average costs for both types of relocation assistance in 2006 were about $€ 1,177$ per participant, which is relatively cheap compared to other ALMP programs (e.g., €6,420 for vocational training programs). Job seekers are not eligible to the subsidy when the employer provides accommodation. Consecutive participation in both program types is possible. The application for the subsidy has to be submitted, together with the employment contract, to the LEA before the move takes place. The final decision about granting the relocation assistance is taken by the caseworker based

\footnotetext{
${ }^{8}$ In addition, the mobility programs also contain measures which are not directly related to regional mobility, e.g., equipment assistance which supports the acquisition of work clothes and tools and transition assistance that provides an interest-free loan to job seekers in order to cover the costs of subsistence until the first wage payment arrives.

${ }^{9}$ In case that the daily commuting time is less than 2.5 hours, the individuals might be eligible for another mobility assistance program. For instance, the commuting assistance pays a subsidy of $€ 0.20$ per kilometer for the first six months in the new job.

${ }^{10}$ The applicant has to provide three cost estimates from a professional moving company to the LEA. The most cost-efficient offer will be chosen. The subsidy is paid directly to the moving company. Alternatively, the agency can also reimburse the costs for a rental car.
} 
on the individual labor market situation of the applicant and the available budget of the local employment agency for mobility assistance programs. In practice, the caseworker indicates to the job seeker whether the subsidy would be approved or not before the job seeker accepts a certain job offer.

\section{[INSERT TABLE 1 ABOUT HERE]}

Table 1 shows the number of entries into unemployment and different ALMP programs in Germany within the considered observation window in the empirical analysis. Besides the number of all entries into mobility assistance programs, we separately show the number of recipients for the program under scrutiny. It can be seen that the relocation assistance is a relatively small program compared to other ALMP programs like vocational training or wage subsidies. Less than $1 \%$ of the total entries into unemployment receive relocation assistance.

\subsection{Related Literature}

The empirical evidence on similar mobility programs is very scarce internationally and nonexistent for Germany. The international evaluation studies indicate positive returns to mobility assistance on labor market outcomes. For instance, Briggs and Kuhn (2008) analyze the Relocation Assistance Program in Kentucky (U.S.) as introduced in May 1998. The program pays a lump sum subsidy of up to $\$ 900$ to households of welfare recipients given that they accept a full-time job offer that is at least 10 miles away from their current place of residence. Using IV estimation, the authors find a positive and significant effect on both employment and unconditional earnings. However, the results are mixed with respect to the earnings conditional on being employed. A second example for the U.S. is the Moving to Opportunity (MTO) program introduced in 1994 by the U.S. Department of Housing and Urban Development in five metropolitan areas, i.e., Baltimore, Boston, Chicago, Los Angeles and New York City. The program was implemented as a randomized experiment where housing vouchers were offered to low-income families in order to move to better neighborhoods. The aim was to improve their health status,

educational opportunities and labor market outcomes. Several studies (e.g. Katz et al., 2001; Ludwig et al., 2005; Kling et al., 2007; Ludwig and Kling, 2007) investigate the effectiveness of this program and find that the MTO program successfully relocated these families to better neighborhoods and partly improved their health status, while there is no significant effect with respect to educational or labor market outcomes. An earlier study by Mueller (1981) finds the U.S. Job Search and Relocation Assistance from 1976 to have a positive effect on the labor market performance of participants. With this program, unemployed individuals who showed a high 
willingness to relocate were offered different types of job search assistance and financial support for the relocation. Descriptive evidence shows that participants end up with better employment prospects and higher wages. With respect to Europe, Rodríguez-Planas and Benus (2010) investigate the effectiveness of employment and relocation services for unemployed individuals in Romania, which reimburses expenses associated with moving to another community. Using propensity score matching, they find that the program has a positive and significant impact on the employment probability and earnings level of participants. Westerlund (1998) analyzes the effect of mobility grants on internal migration in Sweden. Using a regional fixed effects model, he finds no significant effects of varying grants on labor market mobility. However, the migratory behavior of the unemployed responds to changes in the regional labor market conditions.

\section{Data, Settings and Descriptive Statistics}

\subsection{Data}

This study uses the IZA/IAB Administrative Evaluation Dataset, which is based on the Integrated Employment Biographies (IEB) as provided by the Institute for Employment Research (IAB) and consists of a 5\% random sample of entries into unemployment between 2001 and 2008 in Germany. ${ }^{11}$ The IEB are administrative data based on different sources, e.g., employment history, benefit recipient history, training participant history and job search history. They therefore contain detailed information on employment subject to social security contributions, unemployment and participation in active labor market policy including wages and transfer payments. The data additionally include a broad range of socio-economic characteristics including education, family status and health restrictions. The data do not contain information about working hours and periods in self-employment, time spent in inactivity or when individuals work as civil servants.

\subsection{Sample Construction, Settings and Definition of Outcome Variables}

Table 2 shows that the full dataset contains 918,906 individuals. For our analysis, we only consider entries into unemployment ${ }^{12}$ (with a minimum duration of two weeks) in 2005 or 2006 whereby the selected individuals must have been employed for at least three months before entering unemployment with a monthly gross income of $€ 600$ or more. The previous employment

\footnotetext{
${ }^{11}$ This study is based on a weakly anonymized sample of the IEB by the IAB (V.901). The data can be accessed at the Research Data Center of the Federal Employment Agency at the IAB. For a detailed description of this dataset, see Caliendo et al. (2011); Eberle and Schmucker (2015).

${ }^{12}$ We define unemployment as being registered as unemployed at the Federal Employment Agency with or without benefit receipt including participation in ALMP.
} 
and earnings condition guarantees a "fresh" sample of entries into unemployment (no returnees from ALMP or periods of sickness, etc.) making the assumption that the selected individuals indeed search for employment plausible. We do not consider cohorts before 2005 to avoid any structural breaks within our observation window due to a major labor market reform in Germany ("Hartz-Reform"). We also exclude cohorts after 2006 in order to have available a sufficiently large observation window of up to 48 months after entry into unemployment (given that the data in its current version end in December 2010). Table 2 shows that 127,091 individuals are selected based on these criteria.

\section{[INSERT TABLE 2 ABOUt HeRE]}

We further focus on prime-age (25-55 years) male individuals only because female moving behavior is less elastic with respect to factors such as education (e.g. Compton and Pollak, 2007; Brandén, 2013) or occupational choices (e.g. Halfacree, 1995; McKinnish, 2008), and women are sometimes constrained in the relocation decisions of families ("tied movers", e.g. Bielby and Bielby, 1992; Jürges, 2006; Clark and Huang, 2006). Additionally, we find that our instrument, the LEA's provision of mobility programs, only weakly determines the moving decision of women. Therefore, we decided to drop women from the analysis in order to have a clear identification of the treatment effect. Furthermore, we exclude individuals who do not find non-subsidized employment within 24 months after entry into unemployment. This condition is required given that the treatment is perfectly correlated with a transition to employment, i.e., every treated individual finds employment. Therefore, excluding control individuals who do not find employment within this time window reduces the impact of potential unobserved differences between treated and control individuals. ${ }^{13}$ In total, 42,803 individuals remain who fulfill these restrictions (see Table 2).

We further have to imply technical restrictions, i.e., excluding job seekers with implausible information on the subsidy receipt and participants in other mobility programs, in order to define the group of participants and non-participants unambiguously (details are provided in the Supplementary Appendix). After these, the final estimation sample consists of 30,397 individuals in total, where 538 are participants in relocation assistance and 29,859 are non-participants (see Table 2). The low participation rate in our estimation sample corresponds to the overall low

\footnotetext{
${ }^{13}$ Non-subsidized employment is defined as employment subject to social security contributions (excluding ALMP) with a monthly income of at least $€ 600$. The income condition is introduced in order to ensure a certain quality of employment as we do not observe the exact working time in the data. The transition period of 24 months is chosen based on the observation that $98 \%$ of all transitions take place within this time window. We discuss the sensitivity of our estimation with respect to both conditions in Section 5.4 and present further robustness checks.
} 
participation rate in relocation assistance as shown in Table 1, representing the low geographical mobility among the German population.

Figure 1 illustrates the empirical setting of the study (based on two examples). Every individual starts as being unemployed in $t_{0}$ and finds full-time non-subsidized employment within a transition period of 24 months. The exact month of transition is indicated by $t_{u e}$. For example, person 1 starts a new job after six months in unemployment (i.e., $t_{u e}=6$ ). Given that our observation window is restricted to 48 months after entry into unemployment and the transition period consists of 24 months, we can follow each individual after transition to employment for a maximum of 24 months.

\section{[INSERT Figure 1 ABOUT HeRE]}

To answer the research question of whether participation in relocation assistance has an impact on the labor market performance of participants, we consider four baseline outcome variables (see Figure 1): (i) The initial daily wage in the first month in the new job (measured at $\left.t_{u e+1}\right)$. (ii) To measure wage growth and job stability, we consider the maximum observation period after the transition to employment $\left(t_{u e+1}\right.$ until $\left.t_{u e+24}\right)$ and measure the average daily wage and the number of job quits. (iii) We measure the long-term employment probability at

the end of our observation window $\left(t_{u e+24}\right)$. Note, we cannot estimate causal treatment effects with respect to unemployment duration given that we only observe the date of the subsidy payment, which determines the end of unemployment. To assess the impact on unemployment duration, one would need to observe the date of the program announcement to the job seeker, which is unobservable with the data at hand. Therefore, we focus on post-transition outcomes as described before.

\subsection{Descriptive Statistics}

With respect to the individual characteristics, Table 3 shows that participants are positively selected in terms of socio-demographic characteristics and previous labor market performance. Participants are on average younger (37.71 years vs. 38.54 years), better educated (e.g., 39\% vs. $14 \%$ with upper secondary education, $28 \%$ vs. $7 \%$ with an university degree), and less likely to be married and have children (reducing the costs of taking up a distant job). With respect to labor market history, higher shares of participants worked in service occupations before entering unemployment, received a substantially higher wage (€74.29 vs. €67.50) and spent less time in unemployment (360 vs. 480 days) in the past. Moreover, participants also exhibited a higher willingness to commute in the past. On average, $45 \%$ of their jobs during the last five years involved 
daily commuting to a different local employment agency district, while this only applies to $29 \%$ of the non-participants. Furthermore, higher shares of participants had previously participated in any type of mobility assistance (26\% vs. $6 \%)$, i.e., since its introduction in $1998 .{ }^{14}$

\section{[Insert Table 3 and Figure 2 about here]}

Table 3 further shows descriptive statistics with respect to outcome variables. It can be seen that participants remain unemployed longer than non-participants (6.36 vs. 5.39 months). In addition, Figure 2 shows the survival and hazard functions for the transition from unemployment to employment. Non-participants face a higher probability of leaving unemployment, in particular in the beginning of the unemployment spell, which explains the shorter average unemployment duration of non-participants. The longer unemployment duration for participants is somehow surprising given that participants are positively selected in terms of observable labor market characteristics. However, the delay might be explained by higher reservation wages due to an increased job offer arrival rate or due to a time-intensive preparation period of the relocation (searching for distant jobs, finding a new apartment, etc.).

With respect to post-transition labor market outcomes, participants receive higher daily wages at the beginning of the new job $(€ 81.8$ vs. $€ 65.5)$ and also later on $(€ 86.3$ vs. $€ 67.9$ within $t_{u e+1}$ until $\left.t_{u e+24}\right)$, have more stable jobs (0.67 vs. 0.93 job quits within 24 months) and have a higher long-term employment probability in $t_{u e+24}(78 \%$ vs. $73 \%)$.

In addition to the outcome variables, Table 3 shows regional characteristics. Here it becomes clear that, as expected, individuals move predominately to areas characterized by better economic conditions, i.e., lower unemployment rates and higher vacancy rates, or from East to West Germany. Moreover, only a minority of non-participants takes up a distant job at all. While $46 \%$ of participants start a new job in a non-bordering federal state, only $4 \%$ of non-participants do so. On average, the new working location is 188 (33) kilometers away from the place where participants (non-participants) registered as unemployed. ${ }^{15}$ Furthermore, participants predominately move to urban areas.

\section{Empirical Analysis}

The descriptive statistics presented in the previous section suggest that, in particular, individuals with rather positive labor market characteristics and performance in the past select into the

\footnotetext{
${ }^{14}$ The knowledge about the treatment is the main channel to identify the treatment effect (as discussed later on). Controlling for previous program participation rules out (at least to some extent) that endogenous selection into the treatment in the past determines the actual participation and may bias our estimation results.

${ }^{15}$ Distance is measured as the linear distance between the corresponding county seats.
} 
program. Therefore, it is important to control for a large set of individual characteristics when investigating the causal impact of relocation assistance on the labor market performance of participants. Although we have very informative data available that allow us to control for individual (socio-demographics, labor market history etc.) and regional characteristics, it is very likely that the selection into treatment and thus the decision to move to a distant region also depends on unobserved factors, such as individuals' personality or decisions by the caseworker, which are simultaneously correlated with labor market outcomes.

\subsection{The Local Treatment Intensity as Instrumental Variable}

To overcome this endogeneity issue and get unbiased estimates of the treatment effect, we use an instrumental variable approach. The idea is to find an instrument $Z$ that affects individuals' decisions to participate in the program but not the outcome of interest $Y$ (or only through $D$ ) (see for instance, Heckman and Robb, 1985; Imbens and Angrist, 1994; Heckman and Vytlacil, 1999). In this study, we exploit the fact that local employment agencies (LEA) in Germany have a high degree of autonomy when allocating the different types of ALMP programs (including mobility programs) among unemployed job seekers. ${ }^{16}$ In order to understand the idea behind the instrument, we briefly outline the allocation process of ALMP programs. At the beginning of a calendar year, each LEA receives a fixed budget for ALMP programs from the Federal Employment Agency (FEA). While the set of programs is predetermined by the FEA, each LEA decides independently what share of the received budget to spend on which programs, i.e., each LEA determines their own policy mix (see Blien et al., 2009; Fertig et al., 2006). In order to measure this policy mix of the LEA, we define the local treatment intensity $\left(Z_{j t-1}\right)$ as the ratio of entries into mobility programs $\left(N_{j t-1}^{m a}\right)$ and the average stock of unemployed job seekers in each LEA district $j\left(N_{j t-1}^{u e}\right):^{17}$

$$
Z_{j t-1}=\frac{N_{j t-1}^{m a}}{N_{j t-1}^{u e}} \times 100
$$

The numbers are measured in the year before the considered entry window into unemployment ( $t-1)$. This ensures that our estimation sample will not contribute to the construction of the instrument. The instrument ranges between $0.14 \%$ and $44.0 \%$ (with a mean/median at $4.28 / 2.08 \%$ ) within our estimation sample.

\footnotetext{
${ }^{16}$ In Germany, 178 LEAs exist in total within our observation window. Similar regional variations are used as instrumental variables for instance by Briggs and Kuhn (2008), Frölich and Lechner (2010) and Card and Krueger (2000).

${ }^{17}$ Here, we count all entries into mobility programs including in addition to relocation assistance, also commuting assistance, travel cost assistance for distant job interviews, as well as equipment and transition assistance (e.g., for work clothes, and financial aid to bridge the time until receipt of the first salary payment).
} 
The allocation of the budget within a district is based on two dimensions: the local labor market conditions and the preferences of the LEA. We argue that we can eliminate the first part by controlling for detailed local labor market conditions such as the local unemployment rate, availability of vacancies, GDP per capita, industry structure and regional fixed effects. Hence, conditional on these variables, the instrument proxies the LEA's preferences for mobility programs. Given that the job seeker has no influence on the policy mix/preferences of the LEA, the instrument creates exogenous variation with respect to the individual participation decision stemming from an information channel, i.e., a job seeker living in a district with a relatively high treatment intensity is compared to a job seeker in a district with a low treatment intensity more likely to receive knowledge about the existence of the program and hence to participate in relocation assistance. In Germany, every unemployed job seeker will be assigned to a caseworker. The caseworker and the job seeker meet regularly to discuss the job search strategy, including possible ALMP participation. During these meetings, caseworkers in regions with high treatment intensities, and therefore a strong preference for the program, are more likely to inform job seekers about the availability of the program. Once the unemployed receive a job offer which would involve relocation, those living initially in high treatment intensity districts are more likely to accept the offer as the subsidy reduces their reservation wage for distant jobs. In addition to the effect on the behavior of the job seeker, the instrument is also expected to affect the approval decision by the caseworker. In districts with high treatment intensities, applications for relocation assistance are more likely to be approved by the caseworker due to higher program-specific budgets.

\subsection{Estimation Strategy}

Using this instrument, we then estimate the treatment effect using the two-stage least squares estimator (2-SLS, e.g. Angrist and Imbens, 1995):

$$
\begin{aligned}
D_{i} & =\gamma Z_{j}+\beta_{1} X_{i}+\pi_{1} R_{j}+\eta_{j}+U_{i} \\
Y_{i} & =\delta \hat{D}_{i}+\beta_{2} X_{i}+\pi_{2} R_{j}+\eta_{j}+V_{i},
\end{aligned}
$$

where $i$ denotes the individual and $j$ the employment agency. In a first step, we regress the treatment indicator $D_{i}$ on the instrument $Z_{j}$, the observable characteristics $X_{i}$ and the unobservable characteristics $U_{i}$. In a second step, the individual outcome variable $Y_{i}$ is a function of the predicted treatment probabilities $\hat{D}_{i}$, the observed individual characteristics $X_{i}$, the regional information $R_{j}$, and the unobserved characteristics $V_{i}$, while $\delta$ is the parameter of interest. In addition, we include regional fixed effects at the LEA level $\eta_{j}$ in both equations to take unobserved 
regional heterogeneity into account. This is important as, in addition to regional characteristics $R_{j}$, the treatment intensity might be determined by the job seekers' demand for relocation assistance. This would be problematic if there exist unobserved regional differences that influence the local demand for mobility assistance and labor market outcomes simultaneously. For instance, assume that unemployed individuals in region A are generally higher motivated than in other regions and hence are more willing to move in order to find employment. This will increase the demand for relocation assistance in region $\mathrm{A}$ and also lead to better labor market outcomes in region A. Given that the LEA in region A would adjust their policy mix in subsequent years with respect to the increased demand for relocation assistance, the instrument would no longer be independent of the individual labor market outcomes, and estimation results would be biased. Therefore, we include regional fixed effects to capture time-invariant unobserved regional differences, while the time-varying part of these unobserved differences is excluded by using the treatment intensity in the year before a job seeker enters unemployment.

\subsection{Instrumental Variable Conditions and Discussion of Potential Violations}

Assuming that there are heterogeneous effects of the treatment among participants, the instrument $Z_{j}$ has to fulfill three main conditions in order to identify causal local average treatment effects (LATE, see e.g., Imbens and Angrist, 1994). The LATE can be interpreted as the average effect of the treatment on the subgroup of compliers, i.e., the individuals whose participation decision is actually influenced by the instrumental variable.

Relevance The relevance condition requires that the instrument significantly determines the individual participation decision. Table 4 contains the first stage estimation results of equation (2). The first two columns show that the local treatment intensity has a significant impact on the probability of receiving relocation assistance with (column 1) and without (column 2) regional fixed effects. In addition, the resulting F-statistics of testing the joint significance of all instruments (in our case only one) confirms the relevance of the instrument with F-statistics larger than the critical value of 10 , which is usually considered to suggest sufficiently strong instruments (Staiger and Stock, 1997).

\section{[INSERT TABLE 4 ABOUT HERE]}

Exogeneity The second assumption states that the instrument has to be randomly assigned (independence condition) and has to have no influence on the outcome variables other than through its effect on the program participation probability (exclusion restriction). It requires 
the instrument to be jointly independent of individual labor market outcomes and treatment assignment, i.e., the outcome $Y$ with or without treatment is independent of $Z$. As outline above, the conditional instrument $\left(Z_{j} \mid R_{j}, \eta_{j}\right)$ can be expected to reflect LEA's preferences, which should be randomly assigned. In addition to the verbal explanation of the institutional setting, we also apply a regression analysis to convince the reader that the conditional instrument is indeed exogenous (similar to Altonji et al., 2005, who compare individual control variables based on different values of the instrument):

$$
\begin{aligned}
& Z_{j}=\alpha_{1} R_{j}+\eta_{j}+V_{j} \\
& \hat{V}_{j}=\alpha_{2} X_{i}+U_{i}
\end{aligned}
$$

Thereby, we regress in a first step the instrument $Z_{j}$ on regional characteristics $R_{j}$ in the LEA district of origin and regional fixed effects $\eta_{j}$ (Equation 4). The idea is to adjust the instrument $Z_{j}$ for regional economic conditions so that the resulting residuals $\hat{V}_{j}$ solely represent the preferences of the local employment agency for mobility programs. The estimation results in Table 5 show that the regional characteristic $R_{j}$ explains a large and significant part of the variation in $Z_{j}\left(R^{2}=0.621\right.$ without $\eta_{j}$ and $R^{2}=0.862$ including $\left.\eta_{j}\right)$. In a second step, we regress the conditional instrument $\hat{V}_{j}$ on the observed individual characteristics $X_{i}$, which are not included in Equation (4). Table 5 also shows the number of statistically significant coefficients when estimating Equation (5) by OLS. The first column uses the unconditional instrument $Z_{j}$ as a dependent variable, while columns (2) and (3) use the conditional instrument $\hat{V}_{j}$ excluding, (column 2) and respectively including, regional fixed effects (column 3). It can be seen that the number of statistically significant coefficients decreases dramatically from columns (1) to (3), indicating very small correlations between the observed individual characteristics and the instrument conditioning on regional characteristics. In addition, the explanatory power of the estimation decreases dramatically as indicated by the declining $R^{2}$ from columns (1) to (3). This suggests that the conditional instrument creates exogenous variation with respect to the participation decision which cannot be explained by systematic differences between participants and non-participants. Given that we control for a large set of observed individual characteristics (in addition to regional characteristics including regional fixed effects) in our main 2-SLS regression analysis, the remaining unexplained variation of the instrument is even more likely to be exogenous.

[INSERT TABle 5 ABOUt HeRE] 
In addition, we provide graphical evidence for the justification of the independence assumption in Figure 3. The left figure 3a shows the distribution of the unconditional treatment intensity $\left(Z_{j}\right)$ across Germany. Unsurprisingly, the instrument is correlated with local labor market conditions, i.e., the highest treatment intensities can be found in Eastern Germany, while the lowest treatment intensities exist in prosperous areas in the south of Germany. However, our estimation strategy requires the treatment intensity to be exogenous conditional on observable regional characteristics (including regional fixed effects). Therefore, Figure $3 \mathrm{~b}$ shows the distribution of the adjusted instrument $\left(\hat{V}_{j}\right.$ in Equation 5), i.e., the absolute differences with respect to local treatment intensities between 2004 and 2005 conditional on regional characteristics (local unemployment rate, availability of vacancies, GDP per capita and industry structure), which is the source of identification within the fixed effect estimation. Figure $3 \mathrm{~b}$ visually supports our claim that the adjusted instrument is randomly distributed across Germany.

\section{[InsERT Figure 3 ABOUT HERE]}

This evidence makes us very confident that the conditional instrument $\left(Z_{j} \mid R_{j}, \eta_{j}\right)$ is as good as randomly assigned among regions. However, we might still be concerned that the exclusion restriction is violated, i.e., that the instrument might have an influence on the outcome variables other than through its effect on the program participation probability. Here, we could think about two possible violations: (i) if the instrument would be significantly correlated with the individual participation probability in other ALMP programs, i.e., a higher treatment probability in mobility programs might result in a lower participation probability in another program. If this is true, then our instrument might affect $Y$ not through participation in relocation assistance but through not-participating in the other program. To investigate whether this is a relevant channel in our study, we implement a placebo test to check whether the participation in relocation assistance is uniquely determined by the treatment intensity of mobility programs or other ALMP programs (see again Table 4). Therefore, we calculate the treatment intensity for other ALMP programs (job creation schemes, vocational training) and re-estimate the first stage using the alternative instruments. As indicated by the small and insignificant coefficients in columns (3) and (4), as well as the resulting F-statistics that are clearly below the critical value of 10, there is no evidence that the receipt of relocation assistance is correlated with the (non-)participation in other ALMP programs. This makes us confident that the explained channel does not violate the exclusion restriction. (ii) A second potential violation of the exclusion restriction would occur if there is an endogenous regional shock which affects the instrument and the labor market outcomes of participants simultaneously, e.g., firm closure on the local level. To avoid such a 
violation, we use the local treatment intensity with a lag of one year before the entry into unemployment and control for a large set of regional characteristics (including regional fixed effects). Furthermore, it should be noted that usually in Germany additional programs (based on additional funding) are offered to employees in cases where a large firm which has a significant impact on the local labor market closes down. As a consequence, it can be expected that the assignment of ALMP programs are not affected substantially. Finally, we can conclude that the exclusion restriction seems to be a plausible assumption here.

Monotonicity Finally, the monotonicity condition requires that the treatment probability is a (positive) monotonic function of the instrument excluding the presence of defiers. In other words, this excludes individuals who do not participate due to the higher treatment intensity. As the treatment intensity proxies the caseworkers willingness to inform job seekers about the availability of the subsidy and to accept applications, it is very unlikely that there are individuals who face a lower participation probability because of a higher treatment intensity. Hence, we assume that the monotonicity assumption is fulfilled.

\section{Estimation Results}

\subsection{Baseline Results}

Panel A in Table 6 presents our baseline results and shows the marginal effects $(\delta)$ for the four different labor market outcomes as defined in Section 3.3. Besides the IV results (with and without regional fixed effects), we also present the OLS estimates. All specifications include several control variables for socio-demographic characteristics, short- and long-term labor market history, characteristics of the current unemployment spell (e.g., benefit entitlement, duration, other ALMP participation) and local macroeconomic conditions at the time of entry into unemployment. In addition to Table 6, Figure 4 shows the monthly employment effect within our observation window.

\section{[Insert Table 6 And Figure 4 about here]}

The OLS results suggest higher wages and more stable jobs for program participants compared to non-participants, but no significant effect on the long-term employment probability. Using the instrument to control for unobserved terms affecting the selection into relocation assistance leads to even more promising effects, where the positive effect on the long-term probability also becomes statistically significant. Although the inclusion of regional fixed effects (to control 
for regional unobserved heterogeneity that might affect the exogeneity of the instrument) leads to a reduction in point estimates, the treatment effects remain more positive than the OLS results. The results in column (3), which is our preferred specification, suggest that participants earn in the first month of the new job, on average, $25 \%$ more than non-participants. The wage difference declines over time $(16 \%)$ but remains positive and statistically significant. Furthermore, participants experience significantly less job quits within our observation window and have a 24\%-points higher employment probability 24 months after the initial transition from unemployment to the new job. In addition, Figure 4 shows that the positive employment effect is also quite stable over time after an initial adjusting period. In summary, the results suggest that program participation and hence the decision to move to a distant labor market improves the employment prospects of participants substantially.

The differences between the OLS and IV results may be caused by two factors. First, it seems that participants have worse unobserved characteristics, which makes them fail to find employment locally and leave for distant labor markets. A reason for this might be the fact that the potential monetary returns of the relocation - in other words the wage differences between local and distant job offers - are larger for individuals with high (unobserved) abilities, ${ }^{18}$ while the subsidized moving costs are rather fixed. Hence, the relative impact of the subsidy on the moving decision is larger for individuals with low (unobserved) abilities. As the final decision about the approval of the subsidy is up to the caseworker, who is legally constrained to check whether the job seeker could find employment locally or without the subsidy, it seems to be natural that predominately applications of low ability individuals will be approved, and thus OLS estimates are downward biased.

This is also in line with the second explanation, which is based on the fact that the 2-SLS estimator identifies the local average treatment effect (LATE) on those individuals induced to participate in the program due to a change in the instrumental variable (e.g. Angrist et al., 1996; Heckman, 1997; Heckman and Vytlacil, 2005). In our case, this is the effect on those jobseekers who chose the treatment due to the higher treatment intensity in their LEA district. Therefore, our IV results are only informative for a specific subgroup of participants and might differ from the average treatment effect on all treated individuals (ATT). However, we argue that the LATE is the policy relevant parameter here given that policy makers can directly influence the treatment intensity (instrument) and hence the number of job seekers that move due to the existence of the subsidy. We expect that the LATE identifies the treatment effect on those

\footnotetext{
${ }^{18}$ In line with this, Abramitzky (2009) shows, using data from Israeli kibbutzim, that high-ability individuals are more likely to out-migrate from less competitive environments since they can expect large returns to migration.
} 
(low-ability) individuals who would not move in absence of the program but who are, due to the high treatment intensity, induced to change their behavior and collect the potentially large returns of the move.

\subsection{Economic Conditions and Job Match Quality as Underlying Mechanisms}

The positive effect of the moving subsidy on the labor market performance might be explained by three different channels: (i) participants move to regions characterized by better economic conditions compared to their region of origin, (ii) the existence of the subsidy increases the search radius of job seekers, which is likely to also increase the quality of the job match, and (iii) the relocation might have a positive effect on participants' unobserved characteristics, e.g., individuals' motivation or the new social environment, etc.

\section{[INSERT Figure 5 ABOUT HERE]}

While we have no information on the importance of the third aspect (as unobserved with the data at hand), we do provide evidence on the relevance of the first two channels. To do so, we take a closer look at the first wage in the new job and consider an additional outcome variable that measures the relative rank of the realized wage in $t_{u e+1}$ of a participant (non-participant) in the new job within the overall wage distribution in the new (origin) region. The relative rank ranges between 0 and 1 and is independent of the absolute value of the wage. Figure 5 illustrates the underlying idea. Let us assume that an average non-participant in the origin region realizes a nominal daily wage in $t_{u e+1}$ of $€ 60$ in the new job, which corresponds to a relative rank of 0.3 within the regional wage distribution (left side of Figure 5). Now, consider the case of participants. Given that the new region is characterized by better economic conditions, we would expect a wage distribution that is shifted towards the right so that the same relative rank of 0.3 in the new region corresponds to a higher nominal wage (as illustrated by $€ 70$ on the right side of Figure 5). However, if upward job mobility additionally drives the wage effect, we would expect to find a higher relative rank for participants compared to non-participants (who represent the counterfactual situation). In our example, the difference in the nominal wage between $€ 60$ and $€ 70$ arises due to better economic conditions in the new region (shift in wage distribution), while the increase from $€ 70$ to $€ 90$ is due to upward job mobility (increase in job match quality).

Based on this concept, a zero effect in terms of the relative rank would indicate that the positive wage effect in $t_{u e+1}$ of $25 \%$ (as shown in Panel A in Table 6) is just a consequence of the better economic conditions in the new region. In contrast, a positive effect with respect 
to the relative rank would suggest that both the better economic conditions and upward job mobility explain the positive wage effect in $t_{u e+1}$. Moreover, as the industrial composition might differ across regions, we also consider the relative rank within the wage distribution separated by region and sector as an additional outcome variable.

Panel B in Table 6 shows positive and statistically significant effects with respect the relative rank within the regional wage distribution. Based on the IV estimation including regional fixed effects (column 3), participants' wages in $t_{u e+1}$ are located about 22 percentage points closer towards the right of the regional wage distribution compared to non-participants' wages in $t_{u e+1}$. This clearly supports the hypothesis that the positive wage effect in $t_{u e+1}$ of $25 \%$ (as shown in Panel A in Table 6) is driven by both the better economic conditions in the new region and upward job mobility (better job matches) of participants. Although additionally conditioning on the industry sector slightly reduces the effect, it is still positive and statistically significant.

This evidence also contributes to the question of whether people who move (and make use of the subsidy) are really better off in terms of relative wages than those who stay in the region of origin. Unfortunately, we cannot calculate real wages as we have no data on individual consumption available. However, although the regional wage level is one driving factor of regional price differences (see Roos, 2006), the finding that participants move upwards in the wage distribution indicates that the higher nominal wage is not only a manifestation of differences in regional price levels between the region of origin and the new working location. We can conclude that participants are also better off than those who stay in terms of real income.

\subsection{Heterogeneous Treatment Effects}

Another interesting exercise includes the consideration of heterogeneous treatment effects among different subgroups. This might be relevant for two reasons. First of all, it can be assumed that the relocation generates additional monetary and non-monetary costs which are not covered by the subsidy, e.g., school change for children, selling personal property, job change of partner, finding a new apartment/house, leaving social networks behind. ${ }^{19}$ Therefore, given that the additional costs are likely to vary with respect to household size, we might expect to find larger effects for households where children or a partner are present. Secondly, given that the subsidy is the same for all recipients, the incentives to move are larger for those who expect higher returns, while the subsidy is more likely to be necessary to make the relocation cost-effective for those job seekers who expect low returns of the relocation. Therefore, we consider the local

\footnotetext{
${ }^{19}$ In line with this, Brauninger and Tolciu (2011) argue that individual's mobility depend on their social environment, and it is likely that economic incentives (disparities in unemployment rates or wages) and policies (subsidy) might be insufficiently strong enough to affect an individual's decision to move.
} 
unemployment rate and the previous wage level as proxies for a job seeker's potential returns to the relocation. The idea is that people living in regions with relatively poor economic conditions, as well as those with high abilities (which is indicated by a high wage in the previous job), have the largest potential for wage increases when they move to a different local labor market.

\section{[INSERT TABLE 7 ABOUT HERE]}

In order to test for the presence of heterogeneous effects, we re-estimate our baseline model for different subgroups based on certain characteristics indicating individuals' family obligations as well as the local unemployment rate $^{20}$ and previous wages as a proxy for potential returns to the relocation. The estimation results are presented in Table 7. As indicated by the low Fstatistics, for some subgroups, e.g., job seekers with strong family obligations or those living in regions with high unemployment rates, the LEAs preferences have only a limited influence on the individual participation decision. Therefore, the results have to be interpreted with some caution (see, e.g., Bound et al., 1995, who show that 2-SLS estimates are biased towards OLS when the relationship between the instrument and the endogenous variable is weak).

Nevertheless, we find a positive effect on first wages and on the relative rank of the first wage within the LEA district, similar to the baseline estimates for all subgroups. ${ }^{21}$ We interpret the absence of a clear pattern with respect to the non-monetary moving cost and the expected returns of the relocation, as more evidence that the moving subsidy is a suitable instrument in order to improve the labor market performance of unemployed job seekers. It should be noted that the results in column 7 and 8 indicate explicitly stronger relative wage effects for those who have been in the lower part of the wage distribution before entering unemployment.

\subsection{Robustness Analysis}

As we focus on daily wages as the main outcome variable, there might be concerns that our estimates are rather a consequence of participants' higher working hours than increasing hourly wages, which would have different implications for the quality of the job match. Although we have no information on working hours (which prevents us from calculating hourly wages), the data contain indicators for part-time employment. For the main analysis, we refrain from using a more restrictive definition where we condition on full-time employment only, as it would reduce the external validity of the results because it is not required by the institutional settings of the

\footnotetext{
${ }^{20}$ We define regions with low unemployment rates as those LEA districts with an unemployment rate below the median of the federal state.

${ }^{21}$ Since the first wage directly after the transition to employment is already known by the job seeker when making the relocation decision, we expect to see a particularly heterogeneous effect here. For the sake of completeness, we present heterogeneous treatment effects for the full set of outcome variables.
} 
program. However, in order to test the sensitivity of our results with respect to working hours, we re-estimate our baseline results using a more restrictive employment definition. As shown in the Supplementary Appendix, excluding those job seekers who find only part-time employment has nearly no impact on our estimation results. This is not very surprising given that $95 \%$ of the male individuals work full-time. Additionally, it should be noted that the daily wage is calculated based on actual workdays and not based on monthly income. Hence, we can also rule out that systematic differences between participants and non-participants with respect to the number of workdays influences our results.

Moreover, we apply further robustness checks with respect to the definition of our treatment group (details are discussed in the Supplementary Appendix) and the selection into employment within 24 months after the entry into unemployment. The latter might be important as the availability of the subsidy also affects a job seekers initial job finding probability. However, comparing descriptive statistics between participants and non-participants with respect to the employment condition, we find no systematic differences. Moreover, we re-estimate treatment effects for an extended estimation sample without conditioning on a transition to employment. The results indicate, as expected, that including a large number of non-participants with weak labor market outcomes increases the treatment effects but lowers the precision of the estimates. However, all in all, the results presented in the Supplementary Appendix indicate that the positive effects on wages and employment are rather constant with respect to these technical restrictions.

\subsection{Discussion of Economic Implications}

As implied by our baseline results, the moving subsidy has a positive effect of about $25 \%$ on the first daily wage after the transition to regular employment. This seems to be a strong impact in relative terms; however, the absolute wage level of the target population is fairly low. For example, considering the average non-participant in our estimation sample, he could earn about $€ 330$ more per month if he would make use of the subsidy and move to a distant region. Moreover, in the long run, this treatment effect will be reduced to an average of $€ 220$ per month over a period of 2 years, which suggests that about one third of the moving bonus paid by the employer directly after the transition is just an early realization of the overall raise in nominal wages over time, and the wage difference between treated and non-treated decreases in the long-run. Furthermore, the analysis of the effect heterogeneity reveals that the relative wage effects are the largest for job seekers who are initially at the lower end of the wage distribution.

As indicated by the positive effects on the relative rank within a region, and respectively, 
within a sector, the relocation assistance does not only raise participants nominal wage, but it also increases the real disposable income of subsidized movers. This is even more remarkable in the light of the relatively low program costs for the employment agency compared to other ALMP measures. For example, a participant in vocational training creates costs that are about six times larger than a subsidized mover, while vocational training is related to a strong lockingin effect during program participation (e.g. Lechner and Wunsch, 2008). Moreover, positive effects on participants' labor market outcomes are modest and can be found only in the very long run (e.g. Fitzenberger et al., 2008; Lechner et al., 2011). In contrast to this, the relocation assistance implies no locking-in effect in unemployment, and strong positive effects on labor market outcomes are realized in the short-run already.

\section{Conclusion}

We use German administrative data on entries into unemployment in 2005 and 2006 to evaluate the effectiveness of relocation assistance on labor market outcomes. The relocation assistance is part of the German ALMP system and provides unemployed job seekers a subsidy to move to distant labor markets in order to find employment. The main aim of this program is to encourage geographical mobility among the unemployed, expecting an overall reduction in unemployment rates by shifting excess labor supply from depressed to prosperous areas.

The decision to participate in relocation assistance and hence to move to a distant region is likely to be correlated with unobserved factors, such as personality and motivation by the unemployed or considerations by the caseworker. Therefore, we use an IV strategy to identify causal treatment effects. Using the lagged local treatment intensity of mobility assistance programs as a proxy for the local employment agencies' preferences for these programs, the IV estimation results show that receiving the relocation assistance and hence moving to a distant labor market leads to significantly higher wages and more stable jobs in the future compared to non-participants.

Descriptive evidence shows that participants move predominately to regions with better economic conditions. In the causal analysis, we find positive wage and employment effects. In fact, participants have $25 \%$ higher wages in the new job compared to non-participants, a higher job stability over time and also higher employment probabilities in the long-run. While the wage effect appears fairly large at the first glance, one has to take into account that the underlying nominal wage level is rather low, corresponding to an absolute income effect of 330 Euro/month (which is decreasing to 220 Euro/month over time). 
Moreover, we provide evidence that the positive wage effect is not only a manifestation of the change in the economic conditions. Considering the relative rank of the realized wage of a participant (non-participant) in the new job within the overall wage distribution in the new (origin) region, we find that participants move up the wage distribution, including within their new economic environment. Therefore, we conclude that the availability of the subsidy encourages job seekers to search for new jobs nationwide, which raises the number of obtainable vacancies and increases the quality of the job match. Although we have no information on individual consumption available (which would allow a direct assessment of real wages), the finding that participants move upward in the wage distribution indicates that participants are better off than those who do not move. In summary, our results imply strong positive consequences on participants labor market performance in terms of nominal wages, upward job mobility and employment prospects. These results are even more remarkable in the light of the relatively low program costs compared to other ALMP measures, like vocational training, with less positive effects.

The analysis of the effect heterogeneity reveals that our main findings also hold among subgroups with different levels of non-monetary moving costs (which are not captured by the subsidy) and different levels of expected returns. However, even if household and regional characteristics only play a minor role in the effectiveness of the relocation in terms of subsequent income, these characteristics are important for the selection into the program. Additional costs which are not covered by the subsidy, e.g., school change for children, selling personal property, job change of partner, finding a new apartment/house, and leaving social networks behind could prevent job seekers from utilizing the relocation more effectively and lower the influence of the LEA's policy mix on the search behavior of job seekers with children or a partner.

Therefore, if policy makers want to increase the program's currently low take-up and hence further improve geographical mobility among the unemployed, especially among those with strong family obligations, one possible channel - in addition to simply raising the local treatment intensity - would be to increase the subsidy payment beyond the pure transportation costs (particularly given that the current program costs are relatively low compared to other ALMP programs). To increase the efficiency of such a policy, one might vary the amount of the extra payment in addition to the pure transportation costs based on individual/household characteristics, such as marital status or the presence of children. This extra payment would further reduce the job seeker's reservation wage for distant jobs and therefore increase their willingness to move to distant regions even for lower wages. This would help to fill available vacancies in prosperous areas by unemployed job seekers from deprived areas to a larger extent. Such an improvement 
in the aggregate matching function will reduce unemployment on a national level.

Finally, in light of our findings, this paper brings about several important further questions. Unfortunately, because we neither observe the timing of the program announcement (i.e., when the job seeker receives knowledge about the program) nor the actual job search behavior during the unemployment spell, we are prevented from analyzing potential deadweight effects stemming from the fact that some participants might have moved even in the absence of the program. Moreover, with the data at hand, we can only focus on the impact of relocation assistance on post-transition labor market outcomes. Therefore, future research should analyze the impact of the existence of relocation assistance on individuals' job search behavior (reservation wages, intensity etc.) and unemployment duration, as well as general equilibrium effects with respect to the program's possible shifting of excess labor supply from depressed to more prosperous areas. These effects will become even more important when policy makers aim to increase the take-up rates of mobility programs. 


\section{References}

Abramitzky, R. (2009): "The effect of redistribution on migration: Evidence from the Israeli kibbutz," Journal of Public Economics, 93, 498-511.

Altonji, J., T. Elder, And C. TABer (2005): "An evaluation of instrumental variable strategies for estimating the effects of catholic schooling," Journal of Human Resources, 40, 791-821.

Angrist, J. AND G. ImBens (1995): "Two-stage least squares estimation of average causal effects in models with variable treatment intensity," Journal of the American Statistical Association, 90, 431-442.

Angrist, J., G. Imbens, And D. Rubin (1996): "Identification of causal effects using instrumental variables," Journal of the American Statistical Association, 91, 444-455.

Ardington, C., A. Case, and V. Hosegood (2009): "Labor supply responses to large social transfers: Longitudinal evidence from South Africa," American Economic Journal: Applied Economics, 22-48.

ARntz, M. (2005): "The geographical mobility of unemployed workers," ZEW Discussion Paper 05-034.

Arntz, M., T. Gregory, And F. Lehmer (2011): "Unequal pay or unequal employment? What drives the skill-composition of labor flows in Germany?" ZEW Discussion Paper 11-074.

Bentivogli, C. And P. Pagano (1999): "Regional disparities and labour mobility: the Euro-11 versus the USA," Labour, 13, 737-760.

Bielby, W. T. And D. D. Bielby (1992): "I will follow him: Family ties, gender-role beliefs, and reluctance to relocate for a better job," American Journal of Sociology, 1241-1267.

Blanchard, O., L. Katz, R. Hall, and B. Eichengreen (1992): "Regional evolutions," Brookings papers on economic activity, 1992, 1-75.

Blien, U., E. J. Jahn, G. Stephan, R. Hujer, P. J. Rodrigues, and K. Wolf (2009): "Estimating the macroeconomic effects of active labour market policies using spatial econometric methods," International Journal of Manpower, 30, 648-671.

Bonin, H., W. Eichhorst, C. Florman, M. Hansen, L. Skiöld, J. Stuhler, K. Tatsiramos, H. Thomasen, And K. Zimmermann (2008): "Geographic mobility in the European Union: Optimising its economic and social benefits," IZA Research Report 19, Institute for the Study of Labor (IZA).

BorJAs, G. (2006): "Native internal migration and the labor market impact of immigration," Journal of Human Resources, 41, 221-258.

Borjas, G., S. Bronars, and S. Trejo (1992): "Self-selection and internal migration in the United States," Journal of Urban Economics, 32, 159-185.

Bound, J., D. A. JAEger, AND R. M. BAKER (1995): "Problems with instrumental variables estimation when the correlation between the instruments and the endogenous explanatory variable is weak," Journal of the American Statistical Association, 90, 443-450.

BRANDÉn, M. (2013): "Couples' education and regional mobility-the importance of occupation, income and gender," Population, Space and Place, 19, 522-536.

Brauninger, M. AND A. Tolciu (2011): "Should I stay or should I go? Regional mobility and social capital," Journal of Institutional and Theoretical Economics JITE, 167, 434-444.

BRIGGS, B. AND P. KuHn (2008): "Paying for the relocation of welfare recipients: Evidence from the Kentucky Relocation Assistance Program," University of Kentucky Center for Poverty Research Discussion Paper Series DP2008-01. 
BrüCKer, H. AND P. TrüBswetter (2007): "Do the best go west? An analysis of the selfselection of employed East-West migrants in Germany," Empirica, 34, 371-395.

Burda, M. (1993): "The determinants of East-West German migration: Some first results," European Economic Review, 37, 452-461.

Caliendo, M., A. Falk, L. Kaiser, H. Schneider, A. Uhlendorff, G. van den Berg, And K. Zimmermann (2011): "The IZA Evaluation Dataset: Towards evidence-based labor policy making," International Journal of Manpower, 32, 731-752.

Caliendo, M. and J. Hogenacker (2012): "The German Labor Market after the Great Recession: Successful Reforms and Future Challenges," IZA Journal of European Labor Studies, $1: 3,1-24$.

Card, D. And A. B. Krueger (2000): "Minimum wages and employment: a case study of the fast-food industry in New Jersey and Pennsylvania: reply," American Economic Review, $1397-1420$

Clark, W. A. And Y. Huang (2006): "Balancing move and work: women's labour market exits and entries after family migration," Population, Space and Place, 12, 31-44.

Compton, J. And R. A. Pollak (2007): "Why Are Power Couples Increasingly Concentrated in Large Metropolitan Areas?" Journal of Labor Economics, 25, 475-512.

Decressin, J. AND A. FAtÁs (1995): "Regional labor market dynamics in Europe," European Economic Review, 39, 1627-1655.

EBERle, J. AND A. SCHMUCKER (2015): "IZA/IAB Administrativer Evaluationsdatensatz (AED) 1993-2010," FDZ-Datenreport 3/2015, Research Data Centre of the German Federal Employment Agency at the Institute for Employment Research.

Fertig, M., C. M. Schmidt, And H. Schneider (2006): "Active labor market policy in Germany: Is there a successful policy strategy?" Regional Science and Urban Economics, 36, 399-430.

Fitzenberger, B., A. Osikominu, And R. Völter (2008): "Get training or wait? Longrun employment effects of training programs for the unemployed in West Germany," Annales d'Economie et de Statistique, 321-355.

FRÖLICH, M. AND M. LECHNER (2010): "Exploiting regional treatment intensity for the evaluation of labor market policies," Journal of the American Statistical Association, 105, 1014-1029.

FuChS-SChÜNDELn, N. AND M. SchÜNDELn (2009): "Who stays, who goes, who returns?" Economics of Transition, 17, 703-738.

Giannetti, M. (2002): "The effects of integration on regional disparities: Convergence, divergence or both?" European Economic Review, 46, 539 - 567.

HALFACREE, K. H. (1995): "Household migration and the structuration of patriarchy: evidence from the USA." Progress in Human Geography, 19, 159-182.

HeCKMAN, J. (1997): "Instrumental variables: A study of implicit behavioral assumptions used in making program evaluations," Journal of Human Resources, 32.

Heckman, J. And R. RobB (1985): "Alternative methods for evaluating the impact of interventions: An overview," Journal of Econometrics, 30, 239-267.

Heckman, J. And E. Vytlacil (1999): "Local instrumental variables and latent variable models for identifying and bounding treatment effects," Proceedings of the National Academy of Sciences, 96, 4730-4734.

(2005): "Structural equations, treatment effects, and econometric policy evaluation1," Econometrica, 73, 669-738. 
HunT, J. (2006): "Staunching emigration from East Germany: Age and the determinants of migration," Journal of the European Economic Association, 4, 1014-1037.

Imbens, G. AND J. Angrist (1994): "Identification and estimation of local average treatment effects," Econometrica, 62, 467-75.

JÜRGES, H. (2006): "Gender ideology, division of housework, and the geographic mobility of families," Review of Economics of the Household, 4, 299-323.

Katz, L., J. Kling, And J. Liebman (2001): "Moving to opportunity in Boston: Early results of a randomized mobility experiment," The Quarterly Journal of Economics, 116, 607-654.

Kling, J., J. Liebman, And L. Katz (2007): "Experimental analysis of neighborhood effects," Econometrica, 75, 83-119.

Lechner, M., R. Miquel, And C. Wunsch (2011): "Long-Run effects of public sector Sponsored Training in West Germany," Journal of the European Economic Association, 9, 742-784.

Lechner, M. And C. Wunsch (2008): "What did all the money do? On the general ineffectiveness of recent West German labour market programmes," Kyklos, 61, 134-174.

LeHMER, F. AND J. Ludsteck (2011): "The returns to job mobility and inter-regional migration: Evidence from Germany," Papers in Regional Science, 90, 549-571.

Ludwig, J., G. J. Duncan, And J. C. Pinkston (2005): "Housing mobility programs and economic self-sufficiency: Evidence from a randomized experiment," Journal of Public Economics, $89,131-156$.

Ludwig, J. AND J. KLING (2007): "Is crime contagious?" Journal of Law and Economics, 50, $491-518$.

MARINESCU, I. AND R. RATHELOT (2013): "The geography of job search and mismatch unemployment," Working Paper.

McKinnish, T. (2008): "Spousal mobility and earnings," Demography, 45, 829-849.

Mortensen, D. (1986): "Job search and labor market analysis," in Handbook of Labor Economics, ed. by O. Ashenfelter and R. Layard, Elsevier, vol. 2, $849-\overline{919 .}$

Mueller, C. (1981): "Migration of the unemployed: A relocation assistance program," Monthly Lab. Rev., 104, 62.

NiCKELL, S. (1997): "Unemployment and labor market rigidities: Europe versus North America," The Journal of Economic Perspectives, 55-74.

Peukert, C. And W. Smolny (2011): "Interregional migration in Germany: Characteristics and effects for regions and migrants," Discussion paper, University of Ulm.

Puhani, P. (2001): "Labour mobility: an adjustment mechanism in Euroland? Empirical evidence for Western Germany, France and Italy," German Economic Review, 2, 127-140.

Razin, A. And C.-W. Yuen (1997): "Income convergence within an economic union: the role of factor mobility and coordination," Journal of Public Economics, 66, 225-245.

Rodríguez-Planas, N. AND J. Benus (2010): "Evaluating active labor market programs in Romania," Empirical Economics, 38, 65-84.

Rogers, C. (1997): "Job search and unemployment duration: Implications for the spatial mismatch hypothesis," Journal of Urban Economics, 42, 109-132.

Roos, M. W. (2006): "Regional price levels in Germany," Applied Economics, 38, 1553-1566.

Staiger, D. And J. Stock (1997): "Instrumental variables regression with weak instruments," Econometrica, 65, 557-586. 
TAYlor, J. AND S. Bradley (1997): "Unemployment in Europe: A comparative analysis of regional disparities in Germany, Italy and the UK," Kyklos, 50, 221-245.

von Hagen, J. (2000): Institutions, Politics and Fiscal Policy, vol. 2, Springer.

Westerlund, O. (1998): "Internal migration in Sweden: The effects of mobility grants and regional labour market conditions," Labour, 12, 363-388. 


\section{Tables and Figures}

Table 1: Entries in ALMP Programs between 2005 and 2008 (in thousand)

\begin{tabular}{lrrrr}
\hline \hline & 2005 & 2006 & 2007 & 2008 \\
\hline Entries into unemployment & 8,427 & 8,129 & 8,155 & 8,302 \\
Entries into ALMP programs & & & & \\
Mobility assistance (total) & 221 & 281 & 352 & 375 \\
$\quad$ Relocation assistance & 46 & 55 & 68 & 68 \\
Vocational training & 152 & 265 & 360 & 447 \\
Job creation schemes & 78 & 79 & 66 & 67 \\
Wage subsidies & 144 & 226 & 262 & 264 \\
Start-up subsidies & 91 & 76 & 126 & 119 \\
\hline \hline
\end{tabular}

Source: Statistic of the German Federal Employment Agency.

Table 2: Definition of the Estimation Sample

\begin{tabular}{lr}
\hline \hline & Individuals \\
\hline Full sample (entering unemployment $2001-2008)$ & 918,906 \\
Entering unemployment in 2005/2006 ${ }^{a}$ & 127,091 \\
Age restriction $(25-55$ years) & 95,587 \\
Men only & 60,198 \\
Transition to employment within 24 months & 42,803 \\
Definition of treatment status ${ }^{b)}$ & 30,397 \\
& \\
Estimation sample & 538 \\
Participants & 29,859 \\
Non-Participants & \\
& \\
\hline \hline & a) Entries into unemployment are restricted to individuals who were \\
regular employed at least for the last three months before entry into & \\
unemployment with a gross income of at least $€ 600$ per month. \\
b) See Supplementary Appendix for details.
\end{tabular}


Table 3: Selected Descriptive Statistics of Observed Characteristics

Participants Non-participants p-value

No. of observations

538

29,859

Individual characteristics

Socio-demographic characteristics

Age (in years)

37.71

38.54

0.02

(Spec.) Upper sec. degree

0.39

0.14

0.00

University degree

0.28

$0.07 \quad 0.00$

Children

0.33

0.40

0.00

Married

0.49

0.58

0.00

Labor market history

Last daily income (in €)

74.29

67.50

0.00

Time spent in unemployment in last 10 years (in days)

360

480

0.00

Occupation of previous job

Manufacturing

0.36

0.57

0.00

Technical occupation

0.09

0.04

0.00

Services

0.52

0.33

0.00

Share of jobs which involve commuting in last 5 years $^{a}$ )

0.45

0.29

0.00

Previous participation in mobility programs

0.26

0.06

0.00

\section{Outcome variables}

Unemployment duration (in months)

First daily wage in $t_{u e+1}($ in $€)$

Average daily wage from $t_{u e+1}$ to $t_{u e+24}$ (in $€$ )

6.36

5.39

0.00

Number of job quits from $t_{u e+1}$ to $t_{u e+24}$

Employed in $t_{u e+24}$

\section{Regional characteristics}

Local macroeconomic conditions ${ }^{b)}$

Local unemployment rate

at entry in $t_{0}$

after transition in $t_{u e+1}$

0.14

0.13

0.00

Local vacancy rate

at entry in $t_{0}$

after transition in $t_{u e+1}$

0.05

0.06

0.00

0.08

0.06

0.00

Living in East-Germany

at entry in $t_{0}$

0.49

0.31

0.00

after the transition in $t_{u e+1}$

Working location in $t_{u e+1}$ relative to $t_{0}$

in the same federal state

$\begin{array}{ccc}0.26 & 0.88 & 0.00 \\ 0.27 & 0.08 & 0.00 \\ 0.46 & 0.04 & 0.00 \\ 187.7 & 33.2 & 0.00 \\ 0.27 & 0.07 & 0.00 \\ 0.14 & 0.06 & 0.00\end{array}$

in a bordering federal state

in a non-bordering federal state

Distance to new working location in $\mathrm{km}^{c}$ )

Move from non-urban to urban area ${ }^{d)}$

0.14

0.06

0.00

Note: All numbers are shares unless otherwise indicated. Individual characteristics are measured at entry into unemployment $\left(t_{0}\right)$. P-value is based on a t-test on equal means.

a) Jobs outside the own local employment agency district (place of residence) are defined as jobs including daily commuting.

b) Measured at the employment agency district level.

c) Distances between two regions are measured as the linear distance between the corresponding county seats.

d) Cities with more than 100,000 inhabitants are defined as urban areas, all other regions are classified as non-urban. 
Table 4: Summary of First Stage Estimation: Participation in Relocation Assistance

\begin{tabular}{|c|c|c|c|c|}
\hline & \multicolumn{2}{|c|}{ Baseline Model } & \multirow{2}{*}{$\frac{\text { Placebo I }}{(3)}$} & \multirow{2}{*}{$\frac{\text { Placebo II }}{(4)}$} \\
\hline & $(1)$ & $(2)$ & & \\
\hline \multicolumn{5}{|l|}{ Local treatment intensity $\left(Z_{j}\right)$} \\
\hline Mobility programs & $\begin{array}{c}0.104^{* * *} \\
(0.019)\end{array}$ & $\begin{array}{c}0.128^{* * *} \\
(0.031)\end{array}$ & \multirow{3}{*}{$\begin{array}{l}-0.007 \\
(0.007)\end{array}$} & \\
\hline Vocational training & & & & \\
\hline Job creation schemes & & & & $\begin{array}{c}0.022 \\
(0.015)\end{array}$ \\
\hline \multicolumn{5}{|l|}{ Control variables } \\
\hline Socio-demographic characteristics & $\checkmark$ & $\checkmark$ & $\checkmark$ & $\checkmark$ \\
\hline Labor market history & $\checkmark$ & $\checkmark$ & $\checkmark$ & $\checkmark$ \\
\hline Regional information & $\checkmark$ & $\checkmark$ & $\checkmark$ & $\checkmark$ \\
\hline Information on current unemployment spell & $\checkmark$ & $\checkmark$ & $\checkmark$ & $\checkmark$ \\
\hline LEA fixed effects & & $\checkmark$ & & \\
\hline Number of observations & 30,397 & 30,397 & 30,397 & 30,397 \\
\hline F-statistic for weak identification & 30.89 & 16.89 & 0.84 & 1.99 \\
\hline
\end{tabular}

Table 5: The Effect of Observed Characteristics on the Unconditional and Adjusted Instrument

\begin{tabular}{|c|c|c|c|}
\hline & $\begin{array}{c}\text { Unconditional } \\
\text { Instrument } \\
Z_{j} \\
(1)\end{array}$ & $\begin{array}{c}\text { Adjuste } \\
\hat{V}_{j} \\
(2)\end{array}$ & astrument \\
\hline \multicolumn{4}{|l|}{ Equation 4} \\
\hline $\begin{array}{l}\text { Equation } 5 \\
\text { Number of statistically significant coefficients o }\end{array}$ & $X_{i}$ at the $5 \%$-le & & \\
\hline Socio-demographic characteristics & 12 & 2 & 0 \\
\hline Labor market history & 28 & 3 & 4 \\
\hline Information on current unemployment spell & 11 & 10 & 7 \\
\hline Total & 51 & 15 & 11 \\
\hline $\mathrm{R}^{2}$ individual characteristics & 0.326 & 0.011 & 0.009 \\
\hline $\begin{array}{l}\text { LEA fixed effects } \\
\text { Number of observations }\end{array}$ & 30,397 & 30,397 & $\begin{array}{c}\checkmark \\
30,397 \\
\end{array}$ \\
\hline
\end{tabular}

Note: OLS estimation. In total, 73 variables are included in the specification. Full estimation results can be found in the Supplementary Appendix. 
Table 6: Main Estimation Results

\begin{tabular}{|c|c|c|c|c|}
\hline & $\begin{array}{l}\text { Mean non- } \\
\text { participants }\end{array}$ & $\begin{array}{l}\text { OLS } \\
(1)\end{array}$ & $\begin{array}{l}\text { IV } \\
(2)\end{array}$ & $\begin{array}{l}\text { IV } \\
(3)\end{array}$ \\
\hline \multicolumn{5}{|l|}{ A) Baseline Results } \\
\hline Log first daily wage in $t_{u e+1}$ & 65.54 & $\begin{array}{c}0.138^{* * *} \\
(0.015)\end{array}$ & $\begin{array}{c}0.470^{* * *} \\
(0.117)\end{array}$ & $\begin{array}{c}0.245^{* * *} \\
(0.088)\end{array}$ \\
\hline Log average daily wage from $t_{u e+1}$ to $t_{u e+24}$ & 67.93 & $\begin{array}{c}0.145^{* * *} \\
(0.014)\end{array}$ & $\begin{array}{c}0.355^{* * *} \\
(0.109)\end{array}$ & $\begin{array}{l}0.163^{* *} \\
(0.079)\end{array}$ \\
\hline No. of job quits from $t_{u e+1}$ to $t_{u e+24}$ & 0.928 & $\begin{array}{c}-0.126^{* * *} \\
(0.041)\end{array}$ & $\begin{array}{c}-0.875^{* * *} \\
(0.301)\end{array}$ & $\begin{array}{c}-1.027^{* * *} \\
(0.309)\end{array}$ \\
\hline Employed in $t_{u e+24}$ & 0.733 & $\begin{array}{c}0.018 \\
(0.019)\end{array}$ & $\begin{array}{c}0.264^{* *} \\
(0.116)\end{array}$ & $\begin{array}{l}0.243^{* *} \\
(0.100)\end{array}$ \\
\hline
\end{tabular}

\section{B) Better Economic Conditions or Upward Job Mobility?}

Relative rank of first daily wage in $t_{u e+1}$ within the overall wage distribution

$\begin{array}{lcccc}\text { within LEA district } & 0.501 & 0.067^{* * *} & 0.384^{* * *} & 0.224^{* * *} \\ & & (0.010) & (0.081) & (0.059) \\ \text { within LEA district and sector } & 0.512 & 0.066^{* * *} & 0.294^{* * *} & 0.139^{* *} \\ & & (0.010) & (0.078) & (0.059)\end{array}$

Control variables

Socio-demographic characteristics

Labor market history

Regional information

Information on current unemployment spell

LEA fixed effects

No. of observations

$\begin{array}{ll}\checkmark & \checkmark \\ \checkmark & \checkmark \\ \checkmark & \checkmark \\ \checkmark & \checkmark\end{array}$

$\begin{array}{ll}\checkmark & \checkmark \\ \checkmark & \checkmark \\ \checkmark & \checkmark \\ \checkmark & \checkmark \\ & \checkmark\end{array}$

F-statistic for weak identification

Note: Depicted are estimated treatment effects using OLS and 2-SLS estimation. All estimations include several control variables for socio-demographic characteristics, short- and long-term labor market history, benefit entitlement, local macroeconomic conditions at entry into unemployment and the initial unemployment duration. Full estimation results can be found in the Supplementary Appendix. * $/^{* *} / * * *$ indicate statistically significance at the $10 \% / 5 \% / 1 \%$-level. Standard errors are in parenthesis and clustered at the LEA level. 
Table 7: Instrumental Variable Estimation: Heterogenous Treatment Effects

\begin{tabular}{|c|c|c|c|c|c|c|c|c|}
\hline & \multicolumn{2}{|c|}{ Married or cohabiting } & \multicolumn{2}{|c|}{ One child or more } & \multicolumn{2}{|c|}{ Local UE rate } & \multicolumn{2}{|c|}{ Last wage $\geq$ median } \\
\hline & No & Yes & No & Yes & Low & High & No & Yes \\
\hline & (1) & $(2)$ & $(3)$ & (4) & $(5)$ & (6) & (7) & $(8)$ \\
\hline \multicolumn{9}{|l|}{ A) Baseline Results } \\
\hline Log first daily wage in $t_{u e+1}$ & $\begin{array}{c}0.249^{* * *} \\
(0.095)\end{array}$ & $\begin{array}{l}0.181^{*} \\
(0.094)\end{array}$ & $\begin{array}{c}0.215^{* *} \\
(0.097)\end{array}$ & $\begin{array}{c}0.266^{* * *} \\
(0.075)\end{array}$ & $\begin{array}{c}0.262^{* * *} \\
(0.083)\end{array}$ & $\begin{array}{c}0.223^{* *} \\
(0.096)\end{array}$ & $\begin{array}{c}0.502^{* * *} \\
(0.197)\end{array}$ & $\begin{array}{l}0.174^{*} \\
(0.089)\end{array}$ \\
\hline Log average daily wage from $t_{u e+1}$ to $t_{u e+24}$ & $\begin{array}{c}0.186^{* *} \\
(0.088)\end{array}$ & $\begin{array}{l}0.168^{*} \\
(0.089)\end{array}$ & $\begin{array}{c}0.150 \\
(0.098)\end{array}$ & $\begin{array}{c}0.268^{* * *} \\
(0.079)\end{array}$ & $\begin{array}{c}0.262^{* * *} \\
(0.077)\end{array}$ & $\begin{array}{c}0.161^{* *} \\
(0.080)\end{array}$ & $\begin{array}{c}0.473^{* * *} \\
(0.161)\end{array}$ & $\begin{array}{l}0.091 \\
(0.075)\end{array}$ \\
\hline No. of job quits from $t_{u e+1}$ to $t_{u e+24}$ & $\begin{array}{c}-0.852^{* * *} \\
(0.293)\end{array}$ & $\begin{array}{l}-0.553 \\
(0.394)\end{array}$ & $\begin{array}{c}-0.656^{* *} \\
(0.324)\end{array}$ & $\begin{array}{l}-0.508 \\
(0.330)\end{array}$ & $\begin{array}{c}-0.820^{* * *} \\
(0.292)\end{array}$ & $\begin{array}{r}-0.767^{*} \\
(0.429)\end{array}$ & $\begin{array}{l}-0.522 \\
(0.452)\end{array}$ & $\begin{array}{l}-0.434 \\
(0.307)\end{array}$ \\
\hline Employed in $t_{u e+24}$ & $\begin{array}{l}-0.011 \\
(0.141)\end{array}$ & $\begin{array}{l}0.199^{*} \\
(0.117)\end{array}$ & $\begin{array}{c}0.047 \\
(0.140)\end{array}$ & $\begin{array}{c}0.167 \\
(0.114)\end{array}$ & $\begin{array}{c}0.149 \\
(0.117)\end{array}$ & $\begin{array}{c}0.406^{* * *} \\
(0.139)\end{array}$ & $\begin{array}{c}0.091 \\
(0.193)\end{array}$ & $\begin{array}{c}0.118 \\
(0.105)\end{array}$ \\
\hline
\end{tabular}

B) Better Economic Conditions or Upward Job Mobility?

Relative rank of first daily wage in $t_{u e+1}$ within the overall wage distribution

$\begin{array}{lccccccccc}\text { within LEA district } & 0.229^{* * *} & 0.165^{* *} & 0.214^{* * *} & 0.201^{* * *} & 0.187^{* * *} & 0.167^{* *} & 0.476^{* * *} & 0.164^{* *} \\ & (0.072) & (0.078) & (0.069) & (0.068) & (0.054) & (0.071) & (0.146) & (0.068) \\ \text { within LEA district and sector } & 0.143^{*} & 0.100 & 0.122^{*} & 0.220^{* * *} & 0.133^{* *} & 0.097 & 0.368^{* * *} & 0.058 \\ & (0.080) & (0.076) & (0.068) & (0.068) & (0.060) & (0.082) & (0.141) & (0.061)\end{array}$

\begin{tabular}{|c|c|c|c|c|c|c|c|c|}
\hline \multicolumn{9}{|l|}{ Control variables } \\
\hline Socio-demographic characteristics & $\checkmark$ & $\checkmark$ & $\checkmark$ & $\checkmark$ & $\checkmark$ & $\checkmark$ & $\checkmark$ & $\checkmark$ \\
\hline Labor market history & $\checkmark$ & $\checkmark$ & $\checkmark$ & $\checkmark$ & $\checkmark$ & $\checkmark$ & $\checkmark$ & $\checkmark$ \\
\hline Regional information & $\checkmark$ & $\checkmark$ & $\checkmark$ & $\checkmark$ & $\checkmark$ & $\checkmark$ & $\checkmark$ & $\checkmark$ \\
\hline Information on current unemployment spell & $\checkmark$ & $\checkmark$ & $\checkmark$ & $\checkmark$ & $\checkmark$ & $\checkmark$ & $\checkmark$ & $\checkmark$ \\
\hline LEA fixed effects & $\checkmark$ & $\checkmark$ & $\checkmark$ & $\checkmark$ & $\checkmark$ & $\checkmark$ & $\checkmark$ & $\checkmark$ \\
\hline No. of observations & 10,838 & 13,768 & 16,279 & 8,457 & 14,712 & 12,887 & 11,530 & 13,426 \\
\hline No. of participants & 276 & 262 & 357 & 181 & 283 & 255 & 244 & 294 \\
\hline F-statistics for weak identification & 10.10 & 6.83 & 10.95 & 4.95 & 9.01 & 3.99 & 6.01 & 11.35 \\
\hline
\end{tabular}

Note: Depicted are 2-SLS estimation results for different subgroups with and without LEA fixed effects. All estimations include several control variables for socio-demographic characteristics, short- and long-term labor market history, benefit entitlement, local macroeconomic conditions at entry into unemployment, the initial unemployment duration. Low (High) UE rate characterizes LEA districts with an unemployment rate below (above) the median in the corresponding federal state. $* / * / * * *$ indicate statistically significance at the $10 \% / 5 \% / 1 \%$-level. Standard errors are in parenthesis and clustered at the LEA level. 
Figure 1: The Transition Process and Labor Market Outcomes

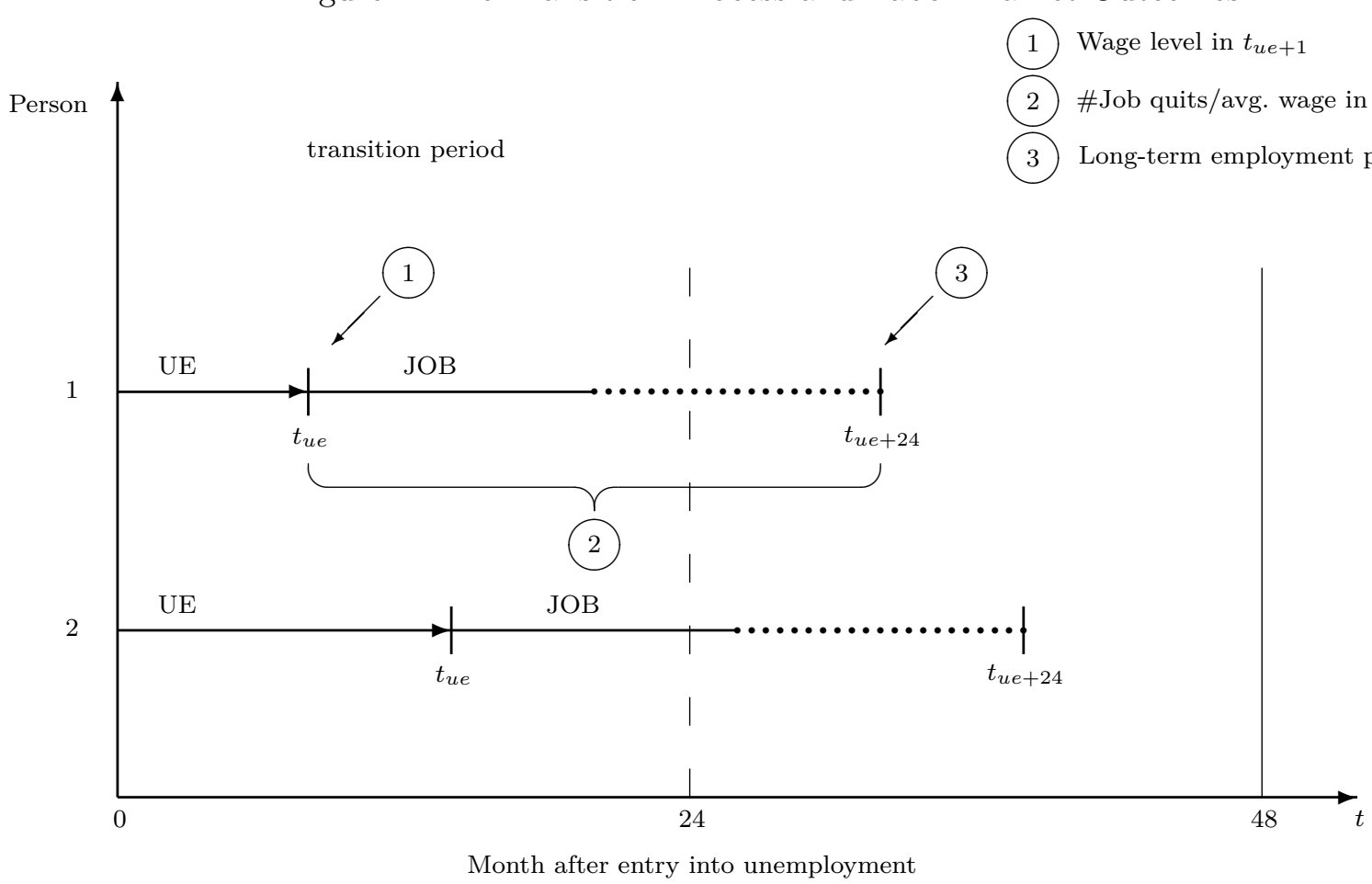

Figure 2: Transition from Unemployment to Employment

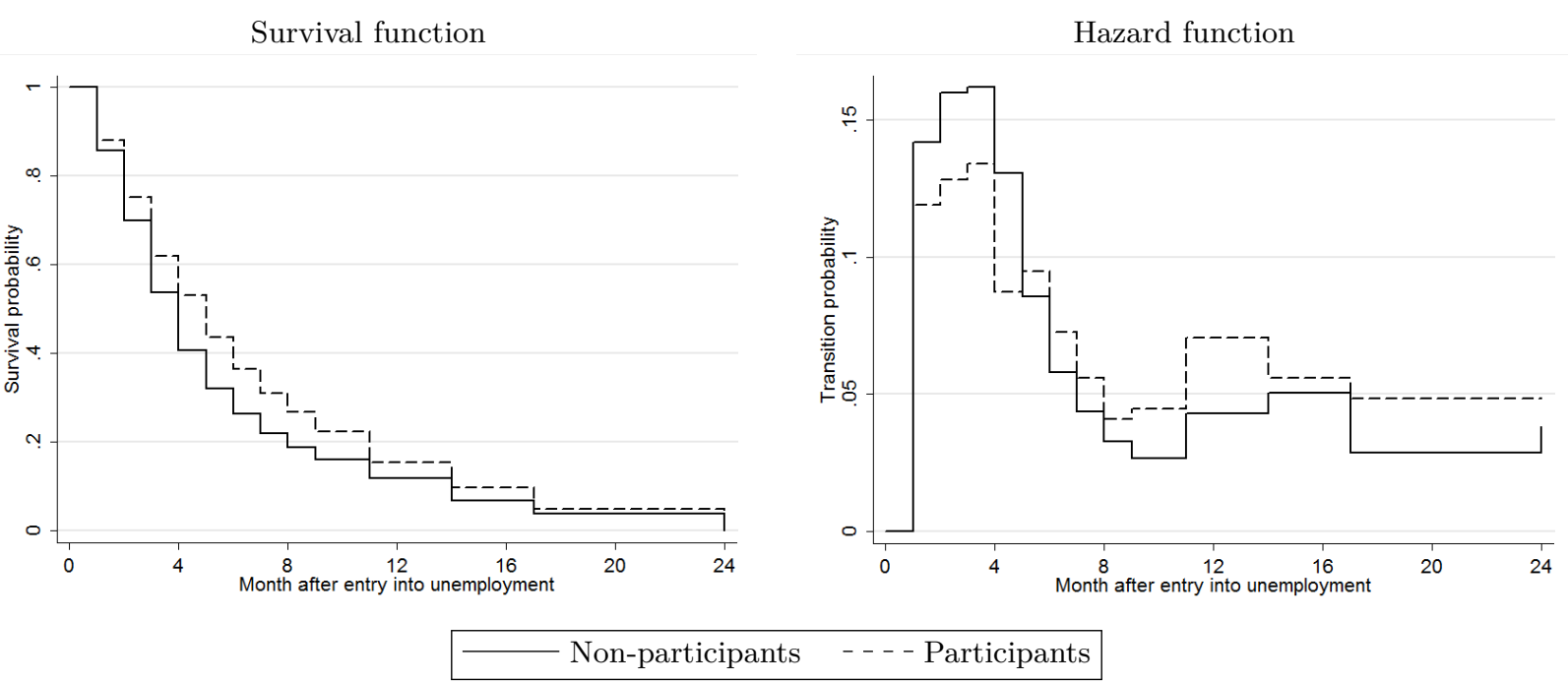

Note: Depicted are unconditional survival and transition probabilities separated for participants and non-participants for the first 24 months after the entry into unemployment. Due to data anonymization reasons, survival and hazard rates are cumulated for months 10-11, 12-14, 15-17 and 18-24. 
Figure 3: Geographical Distribution of Local Treatment Intensities in Germany

(a) Unconditional Treatment Intensity $\left(Z^{2005}\right)$

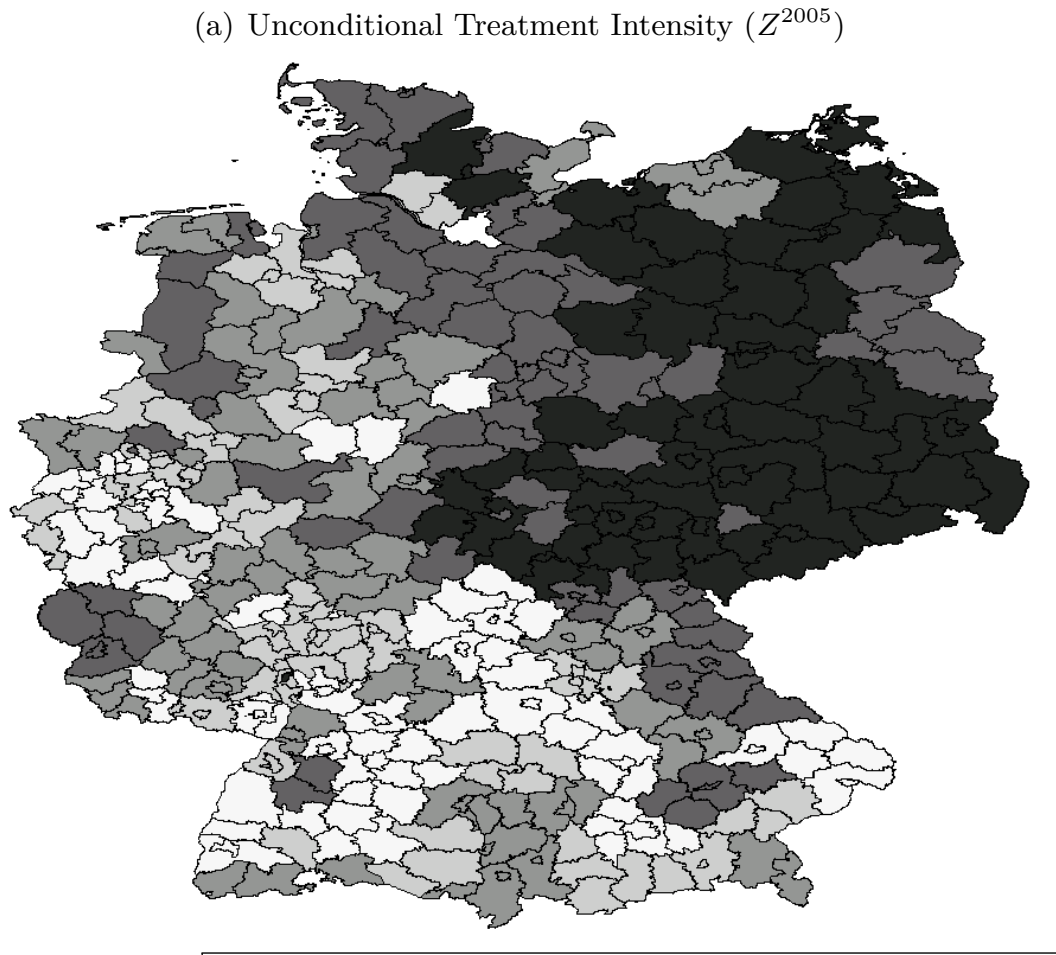

(b) $\left(Z^{2005}-Z^{2004} \mid\right.$ Regional characteristics $)$

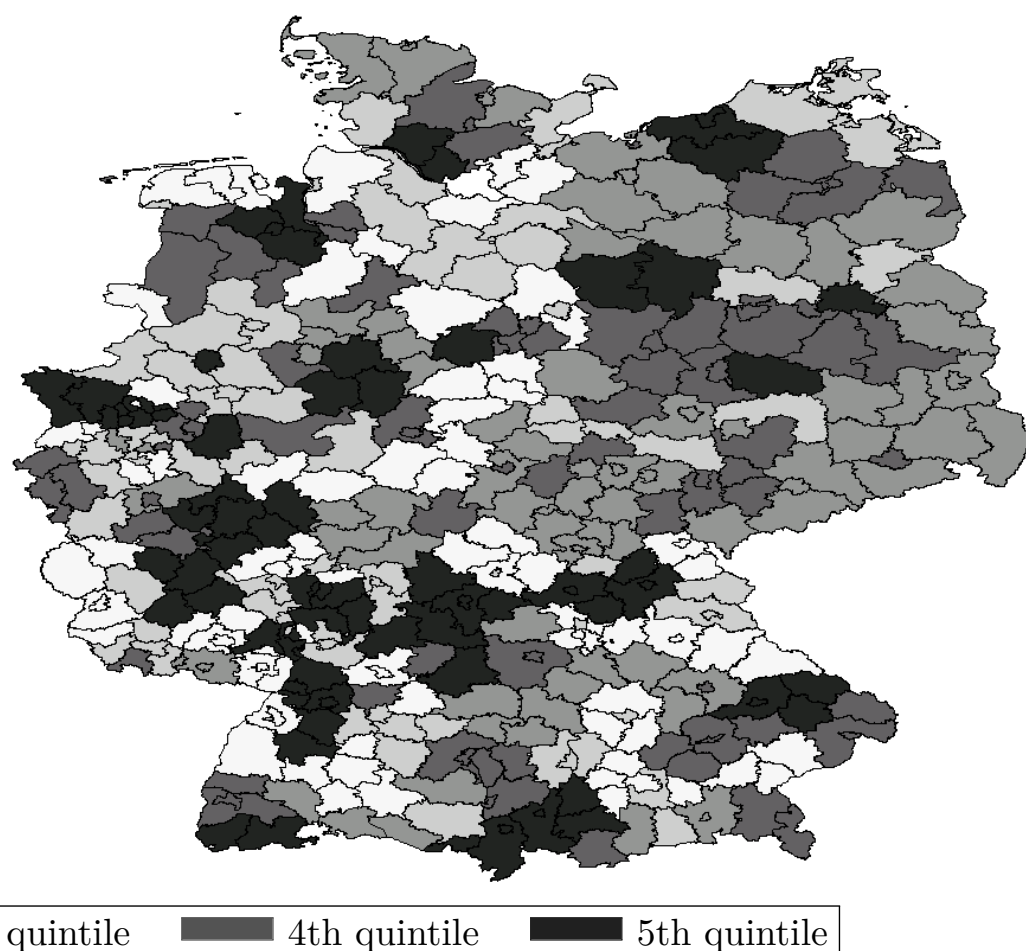

Note: Depicted is the geographical distribution of the unconditional treatment intensity in 2005 (Figure 3a) and the differences between treatment intensities in 2004 and 2005 conditional on regional characteristics (Figure 3b) among Local Employment Agencies in Germany. Source: Statistic of the German Federal Employment Agency. 
Figure 4: Treatment Effect on Monthly Employment Probabilities

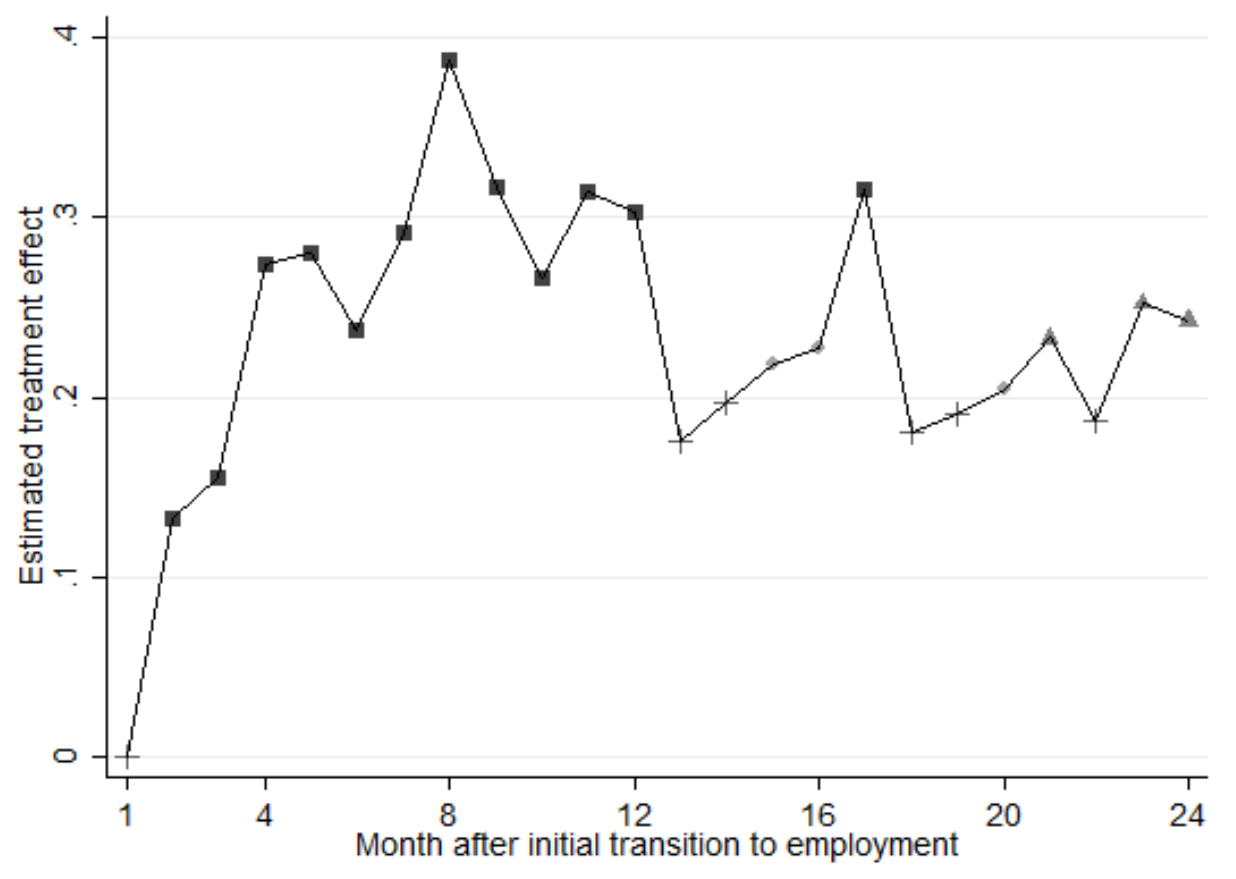

$$
\text { Significance level: } \gg 10 \% \text {-level } \triangle 5 \% \text {-level } \square 1 \% \text {-level }
$$

Note: Depicted are estimated treatment effects of relocation assistance on monthly employment rates for the first 24 months after the transition to regular employment and the corresponding significance levels using 2SLS with LEA fixed effects. Standard errors are clustered at the LEA district level.

Figure 5: Relative Rank in Wage Distribution
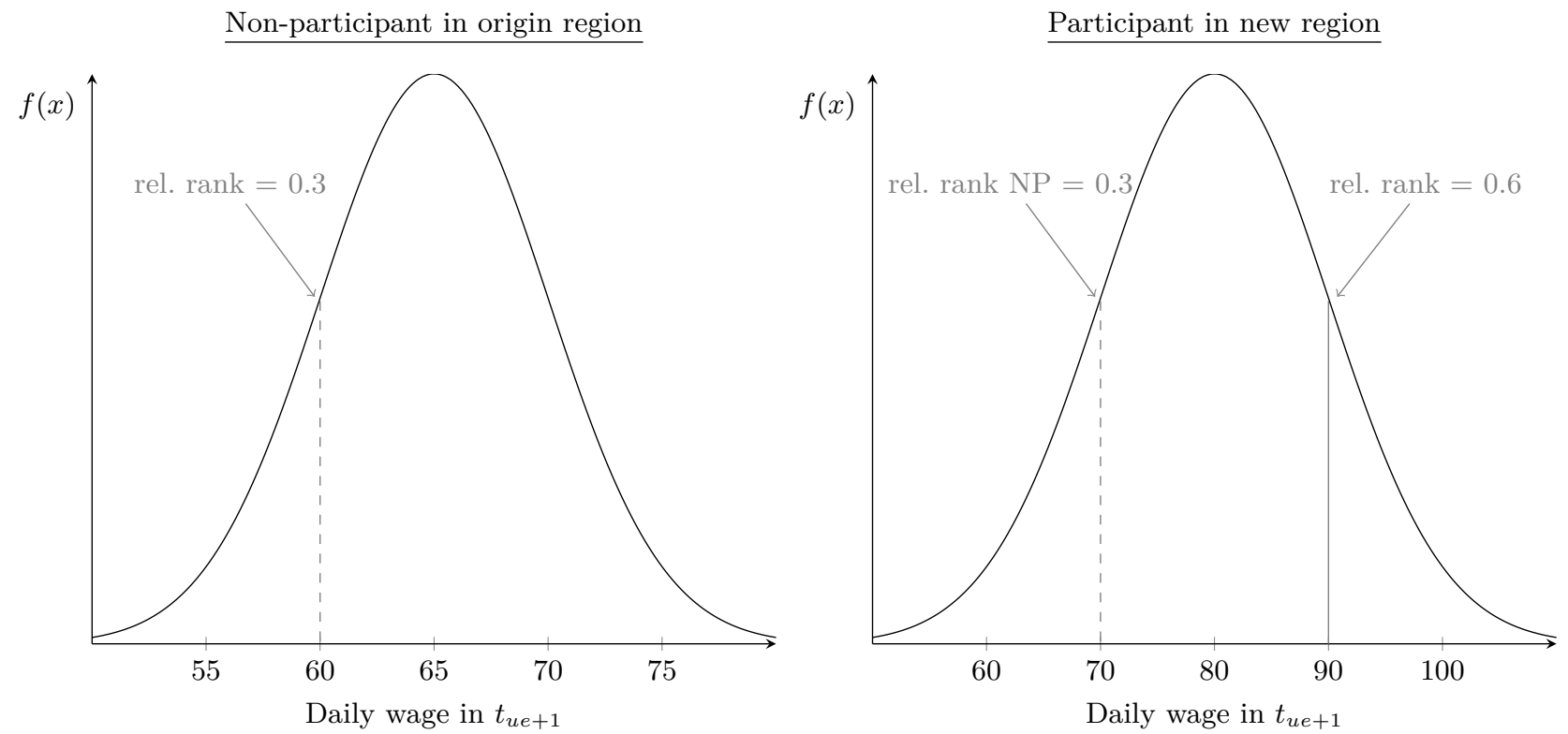

Note: Numbers are artificially chosen and are not based on actual observations. 


\section{Supplementary Appendix}

\section{A Technical Appendix}

Based on the sample of entries into unemployment between 2005 and 2006 who start new employment within 24 months ( $\mathrm{N}=42,803$, see Table 2 in the paper), we need to identify treated individuals, i.e., those who received relocation assistance related to the selected transition to employment. Due to data restrictions, we only observe the exact date at which an individual received the subsidy, but we do not have an identifier available that would allow us to unambiguously merge the subsidy payment to a transition to employment. Therefore, we have to make the following assumptions in order to define the treatment group: (i) The subsidy payment has to take place within a time window of six months before and after the transition to employment, and (ii) as the subsidy payment requires the take up of a distant job, we only keep treated individuals with a change in their residential location, i.e., the place where they initially registered as unemployed must differ from the working location of the new job. Concerning condition (i), we tested different time windows, and six months appeared to be the most appropriate in terms of a trade-off between bias reduction and size of the treatment group. Table A.1 shows the results for all individuals receiving the subsidy payment within a time window of $+/-3$ months around the transition to employment, while Table A.2 shows results for a subsample including only individuals who receive the payment within the first six months after the transition. It can be seen that the estimation results for alternative time windows are very robust compared to our main results reported in Table 6 in the paper; hence, they would lead to the same conclusions. Due to the two assumptions, in total, 82 individuals were excluded from the group of participants. The control group contains all individuals with a transition to employment but without a receipt of relocation assistance, excluding individuals who participate in other mobility programs ( $\mathrm{N}=7,250$ corresponding to $20 \%$ of non-participants). The latter is due to content and methodological reasons. From a content-related view, we exclude participants in other mobility programs in order to estimate a clear effect of participating in relocation assistance, thus avoiding distorting effects due to participants in similar programs in the control group. From a methodological view, the exclusion of participants in other mobility programs from the control group is required to avoid any influence arising from the similarity of the program under scrutiny and to increase the validity of our instrument to identify causal treatment effects. As described in the Section 4 in the paper, our instrument drives the participation in relocation assistance and the other mobility programs simultaneously. Therefore, including recipients of other types of mobility programs in the control group would reduce the power of the instrument to disentangle 
treated and non-treated individuals and hence violate the monotonicity assumption. Moreover, it would harm the exogeneity assumption if the instrument affects the labor market outcome of non-participants who participated in other mobility programs. Finally, we exclude all individuals with missing information in one of the relevant variables $(\mathrm{N}=198)$ as well as all non-participants living in LEA districts without any participants in our estimation sample $(\mathrm{N}=4,876)$, which corresponds to 28 out of the 178 LEA districts. The latter is necessary because we include LEA fixed effects in our estimation procedure. 
Table A.1: Sensitivity Analysis: Treatment Window +/- 3 Months

\begin{tabular}{|c|c|c|c|c|}
\hline & $\begin{array}{l}\text { Mean non- } \\
\text { participants }\end{array}$ & $\begin{array}{l}\text { OLS } \\
(1)\end{array}$ & $\begin{array}{l}\text { IV } \\
(2)\end{array}$ & $\begin{array}{l}\text { IV } \\
(3)\end{array}$ \\
\hline \multicolumn{5}{|l|}{ A) Baseline Results } \\
\hline Log first daily wage in $t_{u e+1}$ & 65.33 & $\begin{array}{c}0.150^{* * *} \\
(0.017)\end{array}$ & $\begin{array}{c}0.466^{* * *} \\
(0.116)\end{array}$ & $\begin{array}{c}0.286^{* * *} \\
(0.091)\end{array}$ \\
\hline Log average daily wage from $t_{u e+1}$ to $t_{u e+24}$ & 67.71 & $\begin{array}{c}0.152^{* * *} \\
(0.015)\end{array}$ & $\begin{array}{c}0.352^{* * *} \\
(0.108)\end{array}$ & $\begin{array}{c}0.199^{* * *} \\
(0.080)\end{array}$ \\
\hline No. of job quits from $t_{u e+1}$ to $t_{u e+24}$ & 0.933 & $\begin{array}{c}-0.117^{* * *} \\
(0.043)\end{array}$ & $\begin{array}{c}-0.788^{* * *} \\
(0.298)\end{array}$ & $\begin{array}{c}-1.043^{* * *} \\
(0.312)\end{array}$ \\
\hline Employed in $t_{u e+24}$ & 0.733 & $\begin{array}{c}0.004 \\
(0.021)\end{array}$ & $\begin{array}{l}0.255^{* *} \\
(0.107)\end{array}$ & $\begin{array}{c}0.202^{* *} \\
(0.096)\end{array}$ \\
\hline
\end{tabular}

\section{B) Better Economic Conditions or Upward Job Mobility?}

Relative rank of first daily wage in $t_{u e+1}$ within the overall wage distribution

$\begin{array}{lcccc}\text { within LEA district } & 0.501 & \begin{array}{c}0.071^{* * *} \\ (0.011)\end{array} & \begin{array}{c}0.387^{* * *} \\ (0.079)\end{array} & \begin{array}{c}0.261^{* * *} \\ (0.059)\end{array} \\ \text { within LEA district and sector } & 0.512 & 0.070^{* * *} & \begin{array}{c}0.304^{* * *} \\ (0.011)\end{array} & \begin{array}{c}0.190^{* * *} \\ (0.059)\end{array} \\ \text { of observations } & & 28,510 & 28,510 & 28,510 \\ \text { tatistic for weak identification } & & & 26.87 & 14.87 \\ \text { A fixed effects } & & & & \checkmark\end{array}$

Note: Depicted are causal treatment effects using OLS and 2-SLS estimation. All estimations include several control variables for socio-demographic characteristics, short- and long-term labor market history, benefit entitlement, local macroeconomic conditions at entry into unemployment and the initial unemployment duration. */**/*** indicate statistically significance at the 10\%/5\%/1\%-level. Standard errors are in parenthesis and clustered at the LEA level. 
Table A.2: Sensitivity Analysis: Treatment Window + 6 Months

\begin{tabular}{|c|c|c|c|c|}
\hline & $\begin{array}{l}\text { Mean non- } \\
\text { participants }\end{array}$ & $\begin{array}{l}\text { OLS } \\
(1)\end{array}$ & $\begin{array}{l}\text { IV } \\
(2)\end{array}$ & $\begin{array}{l}\text { IV } \\
(3)\end{array}$ \\
\hline \multicolumn{5}{|l|}{ A) Baseline Results } \\
\hline Log first daily wage in $t_{u e+1}$ & 65.37 & $\begin{array}{c}0.137^{* * *} \\
(0.016)\end{array}$ & $\begin{array}{c}0.633^{* * *} \\
(0.154)\end{array}$ & $\begin{array}{c}0.329^{* * *} \\
(0.105)\end{array}$ \\
\hline Log average daily wage from $t_{u e+1}$ to $t_{u e+24}$ & 67.76 & $\begin{array}{c}0.147^{* * *} \\
(0.015)\end{array}$ & $\begin{array}{c}0.544^{* * *} \\
(0.136)\end{array}$ & $\begin{array}{c}0.276^{* * *} \\
(0.087)\end{array}$ \\
\hline No. of job quits from $t_{u e+1}$ to $t_{u e+24}$ & 0.933 & $\begin{array}{c}-0.134^{* * *} \\
(0.042)\end{array}$ & $\begin{array}{c}-1.361^{* * *} \\
(0.404)\end{array}$ & $\begin{array}{r}-1.327^{* * *} \\
(0.367)\end{array}$ \\
\hline Employed in $t_{u e+24}$ & 0.733 & $\begin{array}{c}0.019 \\
(0.018)\end{array}$ & $\begin{array}{c}0.380^{* * *} \\
(0.151)\end{array}$ & $\begin{array}{c}0.328^{* * *} \\
(0.114)\end{array}$ \\
\hline
\end{tabular}

B) Better Economic Conditions or Upward Job Mobility?

Relative rank of first daily wage in $t_{u e+1}$ within the overall wage distribution

$\begin{array}{lcccc}\text { within LEA district } & 0.501 & 0.065^{* * *} & 0.519^{* * *} & 0.290^{* * *} \\ & & (0.011) & (0.111) & (0.071) \\ \text { within LEA district and sector } & 0.51 & 0.067^{* * *} & 0.434^{* * *} & \begin{array}{c}0.215^{* * *} \\ (0.070)\end{array} \\ & & (0.010) & (0.112) & 28,993 \\ \text { of observations } & & & 19.86 & 13.05 \\ \text { A fixtic for weak identification } & & & & \checkmark\end{array}$

$\begin{array}{lcc}\text { F-statistic for weak identification } & 19.86 & 13.05 \\ \text { LEA fixed effects } & \checkmark\end{array}$

Note: Depicted are causal treatment effects using OLS and 2-SLS estimation. All estimations include several control variables for socio-demographic characteristics, short- and long-term labor market history, benefit entitlement, local macroeconomic conditions at entry into unemployment and the initial unemployment duration. * $/ * * / * * *$ indicate statistically significance at the $10 \% / 5 \% / 1 \%$-level. Standard errors are in parenthesis and clustered at the LEA level. 


\section{B Supplementary Tables and Figures}

Table B.1: First Stage Estimation Results: Participation in Relocation Assistance

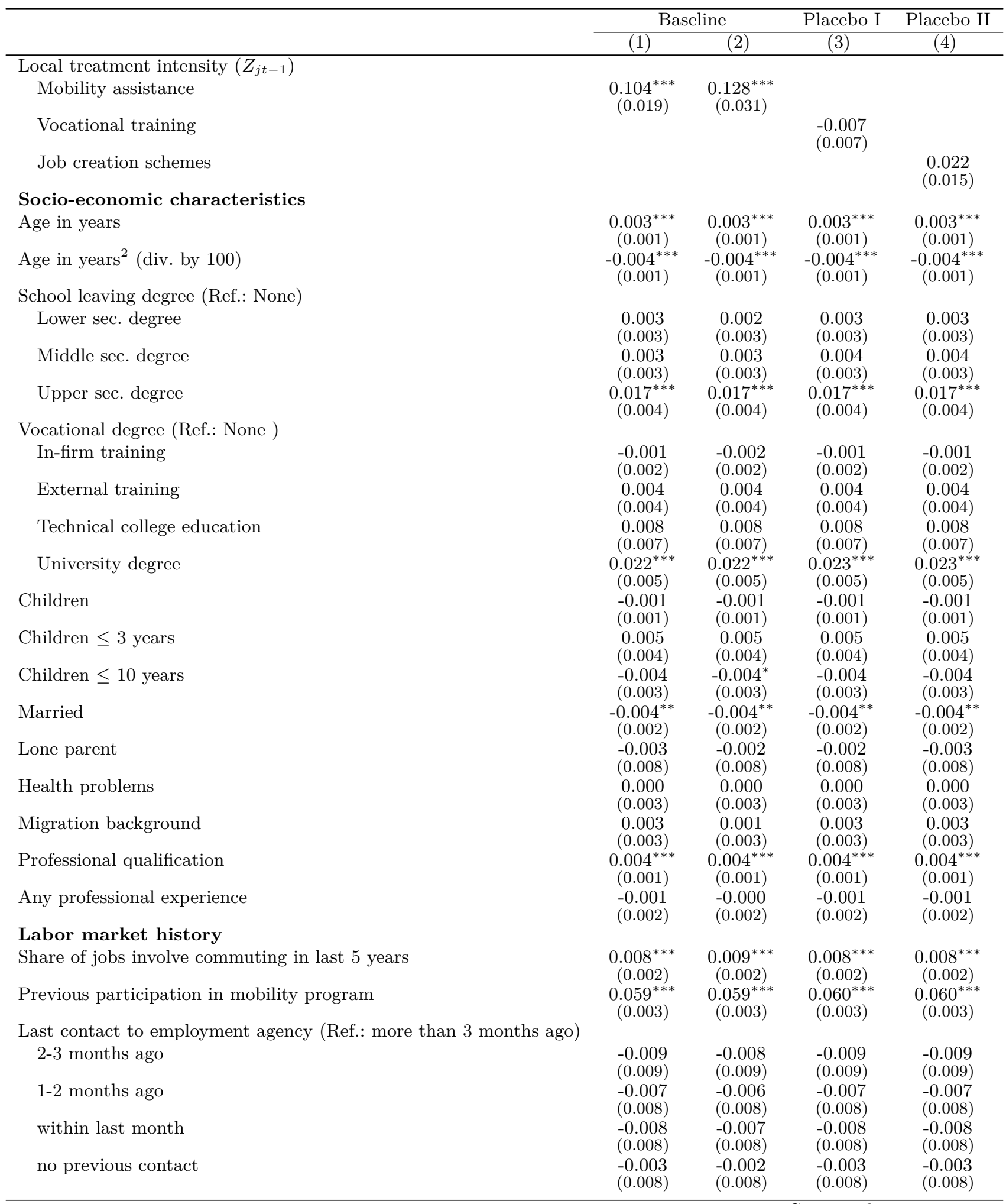


Continued from previous page.

Occupational group of previous job (Ref.: Agriculture)

Manufacturing

Technical occupation

Service

Other

Last job was full-time employment

Log last daily income

Reason for termination of last job: Laid off by employer

Months in employment in year

t-1

$\mathrm{t}-2$

t-3

Months in program in year

t-1

t-2

t-3

Months in unemployment in year

$\mathrm{t}-1$

t-2

$\mathrm{t}-3$

Log average daily wage in year

t-1

t-2

$\mathrm{t}-3$

No. of employers in last 24 months

No. of programs in last 4 years

Months in program in last 4 years

Time spend in unemployment in last 4 years (in 100 days)

Time spend in employment in last 4 years (in 100 days)

Employed 4 years before entry into unemployment

Daily income 4 years before entry into unemployment

Total income in last 4 years (in $€ 10,000$

No. of employers in last 10 years

No. of programs in last 10 years

Months in program in last 10 years

\begin{tabular}{|c|c|c|c|}
\hline $\begin{array}{c}0.001 \\
(0.004)\end{array}$ & $\begin{array}{c}0.000 \\
(0.004)\end{array}$ & $\begin{array}{c}0.001 \\
(0.004)\end{array}$ & $\begin{array}{l}0.001 \\
(0.004)\end{array}$ \\
\hline 0.001 & -0.000 & 0.000 & 0.000 \\
\hline$(0.005)$ & $(0.005)$ & $(0.005)$ & $(0.005)$ \\
\hline $0.009^{* *}$ & $0.010^{* *}$ & $0.009^{* *}$ & $0.009^{* *}$ \\
\hline$(0.004)$ & $(0.004)$ & $(0.004)$ & $(0.004)$ \\
\hline-0.001 & -0.002 & -0.001 & -0.002 \\
\hline$(0.010)$ & $(0.010)$ & $(0.010)$ & $(0.010)$ \\
\hline-0.005 & -0.005 & -0.005 & -0.005 \\
\hline$(0.007)$ & $(0.007)$ & $(0.007)$ & $(0.007)$ \\
\hline-0.006 & -0.005 & -0.005 & -0.006 \\
\hline$(0.005)$ & $(0.005)$ & $(0.005)$ & $(0.005)$ \\
\hline 0.001 & 0.001 & 0.001 & 0.001 \\
\hline (0.003) & $(0.003)$ & (0.003) & $(0.003)$ \\
\hline 0.000 & 0.001 & 0.000 & 0.000 \\
\hline$(0.000)$ & $(0.000)$ & $(0.000)$ & (0.000) \\
\hline-0.000 & -0.000 & 0.000 & 0.000 \\
\hline$(0.000)$ & $(0.000)$ & $(0.000)$ & $(0.000)$ \\
\hline-0.000 & -0.000 & -0.000 & -0.000 \\
\hline$(0.000)$ & $(0.000)$ & $(0.000)$ & $(0.000)$ \\
\hline 0.000 & 0.000 & 0.000 & 0.000 \\
\hline$(0.002)$ & $(0.002)$ & $(0.002)$ & $(0.002)$ \\
\hline-0.000 & -0.000 & -0.000 & -0.000 \\
\hline (0.001) & $(0.001)$ & $(0.001)$ & $(0.001)$ \\
\hline-0.001 & -0.001 & -0.001 & -0.001 \\
\hline$(0.001)$ & $(0.001)$ & $(0.001)$ & $(0.001)$ \\
\hline 0.000 & 0.000 & 0.000 & 0.000 \\
\hline$(0.002)$ & $(0.002)$ & $(0.002)$ & $(0.002)$ \\
\hline-0.001 & -0.001 & -0.001 & -0.001 \\
\hline$(0.001)$ & $(0.001)$ & $(0.001)$ & $(0.001)$ \\
\hline 0.000 & 0.001 & 0.000 & 0.000 \\
\hline$(0.001)$ & $(0.001)$ & $(0.001)$ & $(0.001)$ \\
\hline $0.011^{* *}$ & $0.011^{* *}$ & $0.011^{* *}$ & $0.011^{* *}$ \\
\hline$(0.005)$ & $(0.006)$ & $(0.005)$ & $(0.005)$ \\
\hline 0.000 & 0.000 & 0.000 & 0.000 \\
\hline$(0.000)$ & $(0.000)$ & $(0.000)$ & $(0.000)$ \\
\hline 0.000 & 0.000 & 0.000 & 0.000 \\
\hline$(0.000)$ & $(0.000)$ & $(0.000)$ & $(0.000)$ \\
\hline 0.000 & 0.001 & 0.000 & 0.000 \\
\hline$(0.001)$ & $(0.001)$ & $(0.001)$ & $(0.001)$ \\
\hline 0.003 & 0.003 & 0.003 & 0.003 \\
\hline$(0.002)$ & $(0.002)$ & $(0.002)$ & $(0.002)$ \\
\hline $\begin{array}{l}-0.002 \\
(0.004)\end{array}$ & -0.002 & -0.002 & -0.002 \\
\hline $\begin{array}{l}(0.004) \\
0.000\end{array}$ & $\begin{array}{c}(0.004) \\
0.000\end{array}$ & $\begin{array}{c}(0.004) \\
0.000\end{array}$ & $\begin{array}{c}(0.004) \\
0.000\end{array}$ \\
\hline $\begin{array}{l}0.000 \\
(0.000)\end{array}$ & $\begin{array}{l}0.000 \\
(0.000)\end{array}$ & $\begin{array}{l}0.000 \\
(0.000)\end{array}$ & $\begin{array}{l}0.000 \\
(0.000)\end{array}$ \\
\hline-0.000 & -0.000 & -0.000 & -0.000 \\
\hline$(0.000)$ & $(0.000)$ & $(0.000)$ & $(0.000)$ \\
\hline 0.001 & 0.001 & 0.001 & 0.001 \\
\hline (0.003) & (0.003) & $(0.003)$ & $(0.003)$ \\
\hline-0.000 & -0.000 & -0.000 & -0.000 \\
\hline$(0.000)$ & $(0.000)$ & $(0.000)$ & $(0.000)$ \\
\hline 0.001 & 0.001 & 0.001 & 0.001 \\
\hline$(0.000)$ & $(0.000)$ & $(0.000)$ & $(0.000)$ \\
\hline 0.000 & 0.000 & 0.000 & 0.000 \\
\hline$(0.000)$ & $(0.000)$ & $(0.000)$ & $(0.000)$ \\
\hline$-0.003^{*}$ & $-0.003^{*}$ & $-0.003^{*}$ & $-0.003^{*}$ \\
\hline$(0.001)$ & $(0.001)$ & $(0.001)$ & $(0.001)$ \\
\hline 0.002 & 0.002 & 0.003 & 0.003 \\
\hline$(0.003)$ & $(0.003)$ & $(0.003)$ & (0.003) \\
\hline
\end{tabular}

Continued on next page. 
Continued from previous page.

\begin{tabular}{|c|c|c|c|c|}
\hline Months in unemployment in last 10 years & $\begin{array}{l}-0.000 \\
(0.000)\end{array}$ & $\begin{array}{l}-0.000 \\
(0.000)\end{array}$ & $\begin{array}{l}-0.000 \\
(0.000)\end{array}$ & $\begin{array}{l}-0.000 \\
(0.000)\end{array}$ \\
\hline Time spend in employment in last 10 years (in 100 days) & $\begin{array}{c}0.000 \\
(0.000)\end{array}$ & $\begin{array}{l}-0.000 \\
(0.000)\end{array}$ & $\begin{array}{c}0.000 \\
(0.000)\end{array}$ & $\begin{array}{l}0.000 \\
(0.000)\end{array}$ \\
\hline No. of unemployment spells in last 10 years & $\begin{array}{c}-0.001^{* * *} \\
(0.000)\end{array}$ & $\begin{array}{c}-0.001^{* * *} \\
(0.000)\end{array}$ & $\begin{array}{l}-0.001^{* * *} \\
(0.000)\end{array}$ & $\begin{array}{c}-0.001^{* * *} \\
(0.000)\end{array}$ \\
\hline Total time with last employer in last 10 years & $\begin{array}{l}-0.000 \\
(0.000)\end{array}$ & $\begin{array}{l}-0.000 \\
(0.000)\end{array}$ & $\begin{array}{l}-0.000 \\
(0.000)\end{array}$ & $\begin{array}{l}-0.000 \\
(0.000)\end{array}$ \\
\hline Total income in last 10 years (in $€ 10,000$ ) & $\begin{array}{c}-0.000^{*} \\
(0.000)\end{array}$ & $\begin{array}{c}-0.000^{*} \\
(0.000)\end{array}$ & $\begin{array}{c}-0.000^{*} \\
(0.000)\end{array}$ & $\begin{array}{c}-0.000^{*} \\
(0.000)\end{array}$ \\
\hline Duration of last employment & $\begin{array}{l}-0.000 \\
(0.000)\end{array}$ & $\begin{array}{l}-0.000 \\
(0.000)\end{array}$ & $\begin{array}{l}-0.000 \\
(0.000)\end{array}$ & $\begin{array}{l}-0.000 \\
(0.000)\end{array}$ \\
\hline \multicolumn{5}{|l|}{ Information on current unemployment spell } \\
\hline \multicolumn{5}{|l|}{ Duration of initial unemployment spell (Ref.: 1-3 months) } \\
\hline 4-6 months & $\begin{array}{c}0.003 \\
(0.002)\end{array}$ & $\begin{array}{c}0.003 \\
(0.002)\end{array}$ & $\begin{array}{c}0.003 \\
(0.002)\end{array}$ & $\begin{array}{c}0.003 \\
(0.002)\end{array}$ \\
\hline 7-9 months & $\begin{array}{c}0.007^{* *} \\
(0.003)\end{array}$ & $\begin{array}{c}0.007^{* * *} \\
(0.003)\end{array}$ & $\begin{array}{c}0.006^{* *} \\
(0.003)\end{array}$ & $\begin{array}{c}0.007^{* *} \\
(0.003)\end{array}$ \\
\hline 10-12 months & $\begin{array}{c}0.009^{* * *} \\
(0.003)\end{array}$ & $\begin{array}{c}0.009^{* * *} \\
(0.003)\end{array}$ & $\begin{array}{c}0.009^{* *} \\
(0.003)\end{array}$ & $\begin{array}{c}0.009^{* * *} \\
(0.003)\end{array}$ \\
\hline more than 12 months & $\begin{array}{c}0.002 \\
(0.003)\end{array}$ & $\begin{array}{c}0.002 \\
(0.003)\end{array}$ & $\begin{array}{c}0.002 \\
(0.003)\end{array}$ & $\begin{array}{c}0.002 \\
(0.003)\end{array}$ \\
\hline \multicolumn{5}{|l|}{ Remaining benefit entitlement (Ref.: 0-3 months) } \\
\hline 4-6 months & $\begin{array}{l}-0.003 \\
(0.004)\end{array}$ & $\begin{array}{l}-0.003 \\
(0.004)\end{array}$ & $\begin{array}{l}-0.002 \\
(0.004)\end{array}$ & $\begin{array}{l}-0.002 \\
(0.004)\end{array}$ \\
\hline 7-9 months & $\begin{array}{l}-0.005 \\
(0.004)\end{array}$ & $\begin{array}{l}-0.005 \\
(0.004)\end{array}$ & $\begin{array}{l}-0.004 \\
(0.004)\end{array}$ & $\begin{array}{l}-0.004 \\
(0.004)\end{array}$ \\
\hline 10-12 months & $\begin{array}{c}-0.005^{*} \\
(0.003)\end{array}$ & $\begin{array}{c}-0.005^{*} \\
(0.003)\end{array}$ & $\begin{array}{l}-0.005 \\
(0.003)\end{array}$ & $\begin{array}{l}-0.005 \\
(0.003)\end{array}$ \\
\hline more than 12 months & $\begin{array}{l}-0.002 \\
(0.004)\end{array}$ & $\begin{array}{l}-0.003 \\
(0.004)\end{array}$ & $\begin{array}{l}-0.002 \\
(0.004)\end{array}$ & $\begin{array}{l}-0.002 \\
(0.004)\end{array}$ \\
\hline Any form of non-compliance with benefit conditions & $\begin{array}{c}0.002 \\
(0.002)\end{array}$ & $\begin{array}{c}0.003 \\
(0.002)\end{array}$ & $\begin{array}{c}0.002 \\
(0.002)\end{array}$ & $\begin{array}{c}0.002 \\
(0.002)\end{array}$ \\
\hline Daily unemployment benefits (in $€ 100$ ) & $\begin{array}{c}0.031^{* * *} \\
(0.009)\end{array}$ & $\begin{array}{c}0.031^{* * *} \\
(0.009)\end{array}$ & $\begin{array}{c}0.030^{* * *} \\
(0.009)\end{array}$ & $\begin{array}{c}0.030^{* * *} \\
(0.009)\end{array}$ \\
\hline Year of entry $(=2006)$ & $\begin{array}{c}0.007^{* *} \\
(0.003)\end{array}$ & $\begin{array}{c}0.005 \\
(0.004)\end{array}$ & $\begin{array}{l}0.005^{*} \\
(0.003)\end{array}$ & $\begin{array}{c}0.004 \\
(0.003)\end{array}$ \\
\hline \multicolumn{5}{|l|}{ Month of entry into unemployment (Ref.: Jan.-Mar.) } \\
\hline Apr.-Jun. & $\begin{array}{c}0.003 \\
(0.002)\end{array}$ & $\begin{array}{c}0.002 \\
(0.003)\end{array}$ & $\begin{array}{c}0.003 \\
(0.002)\end{array}$ & $\begin{array}{c}0.004 \\
(0.002)\end{array}$ \\
\hline Jul.-Sep. & $\begin{array}{c}0.006^{* *} \\
(0.003)\end{array}$ & $\begin{array}{l}0.003 \\
(0.003)\end{array}$ & $\begin{array}{c}0.006^{* *} \\
(0.003)\end{array}$ & $\begin{array}{c}0.006^{* *} \\
(0.003)\end{array}$ \\
\hline Oct.-Dec. & $\begin{array}{c}0.002 \\
(0.002)\end{array}$ & $\begin{array}{l}-0.003 \\
(0.003)\end{array}$ & $\begin{array}{c}0.002 \\
(0.002)\end{array}$ & $\begin{array}{c}0.002 \\
(0.002)\end{array}$ \\
\hline Any vacancy referral & $\begin{array}{c}0.001 \\
(0.002)\end{array}$ & $\begin{array}{c}0.001 \\
(0.002)\end{array}$ & $\begin{array}{c}0.001 \\
(0.002)\end{array}$ & $\begin{array}{c}0.001 \\
(0.002)\end{array}$ \\
\hline Participation in other program during current UE spell & $\begin{array}{c}0.012^{* * *} \\
(0.002)\end{array}$ & $\begin{array}{c}0.012^{* * * *} \\
(0.002)\end{array}$ & $\begin{array}{c}0.012^{* * *} \\
(0.002)\end{array}$ & $\begin{array}{c}0.011^{* * *} \\
(0.002)\end{array}$ \\
\hline \multicolumn{5}{|l|}{ Regional characteristics } \\
\hline Living in East-Germany & $\begin{array}{c}0.003 \\
(0.003)\end{array}$ & $\begin{array}{l}-0.026 \\
(0.018)\end{array}$ & $\begin{array}{c}0.012^{* * *} \\
(0.003)\end{array}$ & $\begin{array}{c}0.010^{* * *} \\
(0.003)\end{array}$ \\
\hline Local unemployment rate & $\begin{array}{l}-0.020 \\
(0.032)\end{array}$ & $\begin{array}{c}-0.203^{* *} \\
(0.084)\end{array}$ & $\begin{array}{l}-0.014 \\
(0.033)\end{array}$ & $\begin{array}{l}-0.010 \\
(0.032)\end{array}$ \\
\hline GDP per capita in $€ 10000$ & $\begin{array}{l}-0.001 \\
(0.001)\end{array}$ & $\begin{array}{l}-0.002 \\
(0.001)\end{array}$ & $\begin{array}{l}-0.001 \\
(0.001)\end{array}$ & $\begin{array}{l}-0.001 \\
(0.001)\end{array}$ \\
\hline Local vacancy rate & $\begin{array}{l}-0.038 \\
(0.029)\end{array}$ & $\begin{array}{l}-0.006 \\
(0.048)\end{array}$ & $\begin{array}{l}-0.039 \\
(0.029)\end{array}$ & $\begin{array}{l}-0.038 \\
(0.029)\end{array}$ \\
\hline \multicolumn{5}{|l|}{ Share of working population in (Ref.: Agriculture) } \\
\hline Industry sector & $\begin{array}{l}-0.000 \\
(0.000)\end{array}$ & $\begin{array}{l}-0.000 \\
(0.000)\end{array}$ & $\begin{array}{c}-0.001^{* *} \\
(0.000)\end{array}$ & $\begin{array}{c}-0.001^{* *} \\
(0.000)\end{array}$ \\
\hline Service sector & $\begin{array}{l}-0.000 \\
(0.000)\end{array}$ & $\begin{array}{c}0.000 \\
(0.000)\end{array}$ & $\begin{array}{c}-0.001^{* * *} \\
(0.000)\end{array}$ & $\begin{array}{c}-0.001^{* * *} \\
(0.000)\end{array}$ \\
\hline LEA fixed effects & & $\checkmark$ & & \\
\hline No. of observations & 30,397 & 30,397 & 30,397 & 30,397 \\
\hline F-statistic for weak identification & 30.89 & 16.89 & 0.84 & 1.99 \\
\hline
\end{tabular}

Note: Dependent variable: $D_{i}$ (treatment indicator). OLS estimation. ${ }^{*} / * / * * *$ indicates significance at the $10 \% / 5 \% / 1 \%$-level. Standard errors are in parenthesis and clustered at the LEA-level. 
Table B.2: The Effect of Observed Characteristics on the Unconditional and Adjusted Instrument

\begin{tabular}{|c|c|c|c|}
\hline \multirow{3}{*}{ Socio-demographic characteristics } & \multirow{2}{*}{$\begin{array}{c}\text { Unconditional } \\
\text { Instrument } \\
Z_{j} \\
(1)\end{array}$} & \multicolumn{2}{|c|}{ Adjusted Instrument } \\
\hline & & $\begin{array}{c}\hat{V}_{j} \\
(2)\end{array}$ & $\frac{\hat{V}_{j}}{(3)}$ \\
\hline & & & \\
\hline Age in years & $\begin{array}{c}0.002^{* * *} \\
(0.000)\end{array}$ & $\begin{array}{r}0.000 \\
(0.000)\end{array}$ & $\begin{array}{r}0.000 \\
(0.000)\end{array}$ \\
\hline Age in years ${ }^{2}$ (div. by 100$)$ & $\begin{array}{c}-0.001^{* * *} \\
(0.001)\end{array}$ & $\begin{array}{l}-0.000 \\
(0.000)\end{array}$ & $\begin{array}{l}-0.000 \\
(0.000)\end{array}$ \\
\hline \multicolumn{4}{|l|}{ School leaving degree (Ref.: None) } \\
\hline Lower sec. degree & $\begin{array}{c}-0.006^{* * *} \\
(0.001)\end{array}$ & $\begin{array}{r}0.001 \\
(0.001)\end{array}$ & $\begin{array}{l}0.000 \\
(0.001)\end{array}$ \\
\hline Middle sec. degree & $\begin{array}{c}0.029^{* * *} \\
(0.001)\end{array}$ & $\begin{array}{c}0.003^{* * *} \\
(0.001)\end{array}$ & $\begin{array}{c}0.001 \\
(0.001)\end{array}$ \\
\hline Upper sec. degree & $\begin{array}{c}0.003 \\
(0.002)\end{array}$ & $\begin{array}{c}0.002 \\
(0.001)\end{array}$ & $\begin{array}{c}0.001 \\
(0.001)\end{array}$ \\
\hline \multicolumn{4}{|l|}{ Vocational degree (Ref.: None) } \\
\hline In-firm training & $\begin{array}{c}0.018^{* * *} \\
(0.001)\end{array}$ & $\begin{array}{c}0.001 \\
(0.001)\end{array}$ & $\begin{array}{l}-0.000 \\
(0.000)\end{array}$ \\
\hline External training & $\begin{array}{c}0.010^{* * *} \\
(0.002)\end{array}$ & $\begin{array}{l}0.000 \\
(0.001)\end{array}$ & $\begin{array}{l}-0.001 \\
(0.001)\end{array}$ \\
\hline Technical college education & $\begin{array}{l}-0.003 \\
(0.003)\end{array}$ & $\begin{array}{l}-0.001 \\
(0.002)\end{array}$ & $\begin{array}{l}-0.001 \\
(0.001)\end{array}$ \\
\hline University degree & $\begin{array}{c}0.022^{* * *} \\
(0.002)\end{array}$ & $\begin{array}{r}0.002 \\
(0.001)\end{array}$ & $\begin{array}{c}0.000 \\
(0.001)\end{array}$ \\
\hline Children & $\begin{array}{l}0.000 \\
(0.001)\end{array}$ & $\begin{array}{l}-0.000 \\
(0.000)\end{array}$ & $\begin{array}{l}-0.000 \\
(0.000)\end{array}$ \\
\hline Children $\leq 3$ years & $\begin{array}{l}-0.001 \\
(0.002)\end{array}$ & $\begin{array}{c}0.000 \\
(0.001)\end{array}$ & $\begin{array}{r}0.001 \\
(0.001)\end{array}$ \\
\hline Children $\leq 10$ years & $\begin{array}{l}-0.001 \\
(0.001)\end{array}$ & $\begin{array}{c}0.001 \\
(0.001)\end{array}$ & $\begin{array}{l}-0.001 \\
(0.000)\end{array}$ \\
\hline Married & $\begin{array}{c}0.007^{* * *} \\
(0.001)\end{array}$ & $\begin{array}{r}0.000 \\
(0.001)\end{array}$ & $\begin{array}{r}0.000 \\
(0.000)\end{array}$ \\
\hline Lone parent & $\begin{array}{r}0.004 \\
(0.003)\end{array}$ & $\begin{array}{c}0.000 \\
(0.002)\end{array}$ & $\begin{array}{l}-0.002 \\
(0.001)\end{array}$ \\
\hline Health problems & $\begin{array}{c}-0.003^{* *} \\
(0.001)\end{array}$ & $\begin{array}{r}0.001 \\
(0.001)\end{array}$ & $\begin{array}{r}0.001 \\
(0.001)\end{array}$ \\
\hline Migration background & $\begin{array}{c}-0.007^{* * *} \\
(0.001)\end{array}$ & $\begin{array}{r}0.000 \\
(0.001)\end{array}$ & $\begin{array}{l}-0.000 \\
(0.000)\end{array}$ \\
\hline Professional qualification & $\begin{array}{l}0.003^{* * *} \\
(0.001)\end{array}$ & $\begin{array}{l}-0.001 \\
(0.000)\end{array}$ & $\begin{array}{c}0.000 \\
(0.000)\end{array}$ \\
\hline Any professional experience & $\begin{array}{c}-0.004^{* * *} \\
(0.001)\end{array}$ & $\begin{array}{c}-0.002^{* *} \\
(0.001)\end{array}$ & $\begin{array}{l}-0.001 \\
(0.000)\end{array}$ \\
\hline \multicolumn{4}{|l|}{ Labor market history } \\
\hline Share of jobs involving commuting in last 5 years & $\begin{array}{c}0.003^{* * *} \\
(0.001)\end{array}$ & $\begin{array}{c}-0.002^{* *} \\
(0.001)\end{array}$ & $\begin{array}{r}0.000 \\
(0.000)\end{array}$ \\
\hline Previous participation in mobility program & $\begin{array}{c}0.029^{* * *} \\
(0.001)\end{array}$ & $\begin{array}{c}0.006^{* * *} \\
(0.001)\end{array}$ & $\begin{array}{l}-0.001^{*} \\
(0.001)\end{array}$ \\
\hline \multicolumn{4}{|c|}{ Last contact to employment agency (Ref.: more than 3 months ago) } \\
\hline 2-3 months ago & $\begin{array}{l}-0.006 \\
(0.004)\end{array}$ & $\begin{array}{l}-0.001 \\
(0.003)\end{array}$ & $\begin{array}{r}0.002 \\
(0.002)\end{array}$ \\
\hline 1-2 months ago & $\begin{array}{c}-0.007^{* *} \\
(0.003)\end{array}$ & $\begin{array}{c}0.001 \\
(0.003)\end{array}$ & $\begin{array}{c}0.002 \\
(0.002)\end{array}$ \\
\hline within last month & $\begin{array}{c}-0.005^{*} \\
(0.003)\end{array}$ & $\begin{array}{l}-0.001 \\
(0.002)\end{array}$ & $\begin{array}{c}0.001 \\
(0.001)\end{array}$ \\
\hline no previous contact & $\begin{array}{l}-0.003 \\
(0.003)\end{array}$ & $\begin{array}{l}-0.002 \\
(0.002)\end{array}$ & $\begin{array}{c}0.001 \\
(0.001)\end{array}$ \\
\hline
\end{tabular}


Continued from previous page.

\begin{tabular}{|c|c|c|c|}
\hline \multicolumn{4}{|l|}{ Occupational group of previous job (Ref.: Agriculture) } \\
\hline Manufacturing & $\begin{array}{l}0.003^{*} \\
(0.001)\end{array}$ & $\begin{array}{c}-0.000 \\
(0.001)\end{array}$ & $\begin{array}{l}-0.000 \\
(0.001)\end{array}$ \\
\hline Technical occupation & $\begin{array}{c}0.001 \\
(0.002)\end{array}$ & $\begin{array}{l}-0.001 \\
(0.002)\end{array}$ & $\begin{array}{c}-0.002^{*} \\
(0.001)\end{array}$ \\
\hline Service & $\begin{array}{c}-0.006^{* * *} \\
(0.002)\end{array}$ & $\begin{array}{l}-0.001 \\
(0.001)\end{array}$ & $\begin{array}{l}-0.001 \\
(0.001)\end{array}$ \\
\hline Other & $\begin{array}{l}-0.003 \\
(0.004)\end{array}$ & $\begin{array}{l}-0.004 \\
(0.003)\end{array}$ & $\begin{array}{l}-0.001 \\
(0.002)\end{array}$ \\
\hline Last job was full-time employment & $\begin{array}{c}0.021^{* * *} \\
(0.003)\end{array}$ & $\begin{array}{c}0.001 \\
(0.002)\end{array}$ & $\begin{array}{c}0.002 \\
(0.001)\end{array}$ \\
\hline Log last daily income & $\begin{array}{c}-0.006^{* * *} \\
(0.002)\end{array}$ & $\begin{array}{c}0.001 \\
(0.001)\end{array}$ & $\begin{array}{l}-0.000 \\
(0.001)\end{array}$ \\
\hline Reason for termination of last job: Laid off by employer & $\begin{array}{c}0.001 \\
(0.001)\end{array}$ & $\begin{array}{c}0.000 \\
(0.001)\end{array}$ & $\begin{array}{c}0.000 \\
(0.001)\end{array}$ \\
\hline \multicolumn{4}{|l|}{ Months in employment in year } \\
\hline $\mathrm{t}-1$ & $\begin{array}{c}-0.001^{* * *} \\
(0.000)\end{array}$ & $\begin{array}{l}-0.000 \\
(0.000)\end{array}$ & $\begin{array}{l}-0.000 \\
(0.000)\end{array}$ \\
\hline $\mathrm{t}-2$ & $\begin{array}{c}0.001^{* * *} \\
(0.000)\end{array}$ & $\begin{array}{l}0.000^{*} \\
(0.000)\end{array}$ & $\begin{array}{r}0.000 \\
(0.000)\end{array}$ \\
\hline $\mathrm{t}-3$ & $\begin{array}{c}0.001^{* * *} \\
(0.000)\end{array}$ & $\begin{array}{c}0.000^{* *} \\
(0.000)\end{array}$ & $\begin{array}{c}0.000 \\
(0.000)\end{array}$ \\
\hline \multicolumn{4}{|l|}{ Months in program in year } \\
\hline $\mathrm{t}-1$ & $\begin{array}{l}-0.000 \\
(0.001)\end{array}$ & $\begin{array}{r}0.000 \\
(0.000)\end{array}$ & $\begin{array}{c}-0.000 \\
(0.000)\end{array}$ \\
\hline $\mathrm{t}-2$ & $\begin{array}{c}0.000 \\
(0.000)\end{array}$ & $\begin{array}{l}0.000^{*} \\
(0.000)\end{array}$ & $\begin{array}{l}0.000^{* *} \\
(0.000)\end{array}$ \\
\hline $\mathrm{t}-3$ & $\begin{array}{l}-0.000 \\
(0.000)\end{array}$ & $\begin{array}{c}-0.000 \\
(0.000)\end{array}$ & $\begin{array}{l}-0.000 \\
(0.000)\end{array}$ \\
\hline \multicolumn{4}{|l|}{ Months in unemployment in year } \\
\hline $\mathrm{t}-1$ & $\begin{array}{c}0.000 \\
(0.001)\end{array}$ & $\begin{array}{l}-0.000 \\
(0.001)\end{array}$ & $\begin{array}{l}-0.000 \\
(0.000)\end{array}$ \\
\hline $\mathrm{t}-2$ & $\begin{array}{c}-0.002^{* * *} \\
(0.000)\end{array}$ & $\begin{array}{c}0.000 \\
(0.000)\end{array}$ & $\begin{array}{c}0.000 \\
(0.000)\end{array}$ \\
\hline $\mathrm{t}-3$ & $\begin{array}{c}-0.002^{* * *} \\
(0.000)\end{array}$ & $\begin{array}{l}-0.000 \\
(0.000)\end{array}$ & $\begin{array}{c}0.000 \\
(0.000)\end{array}$ \\
\hline \multicolumn{4}{|l|}{ Log average daily wage in year } \\
\hline $\mathrm{t}-1$ & $\begin{array}{c}-0.022^{* * *} \\
(0.002)\end{array}$ & $\begin{array}{l}-0.002 \\
(0.002)\end{array}$ & $\begin{array}{c}0.001 \\
(0.001)\end{array}$ \\
\hline $\mathrm{t}-2$ & $\begin{array}{c}0.000 \\
(0.000)\end{array}$ & $\begin{array}{c}0.000 \\
(0.000)\end{array}$ & $\begin{array}{l}-0.000 \\
(0.000)\end{array}$ \\
\hline $\mathrm{t}-3$ & $\begin{array}{c}-0.000^{* * *} \\
(0.000)\end{array}$ & $\begin{array}{l}-0.000 \\
(0.000)\end{array}$ & $\begin{array}{c}-0.000^{* *} \\
(0.000)\end{array}$ \\
\hline No. of employers in last 24 months & $\begin{array}{c}-0.004^{* * *} \\
(0.000)\end{array}$ & $\begin{array}{l}-0.000^{*} \\
(0.000)\end{array}$ & $\begin{array}{l}-0.000 \\
(0.000)\end{array}$ \\
\hline No. of programs in last 4 years & $\begin{array}{c}-0.002^{* *} \\
(0.001)\end{array}$ & $\begin{array}{r}0.000 \\
(0.001)\end{array}$ & $\begin{array}{c}0.001^{* *} \\
(0.000)\end{array}$ \\
\hline Months in program in last 4 years & $\begin{array}{l}-0.003 \\
(0.002)\end{array}$ & $\begin{array}{c}-0.000 \\
(0.001)\end{array}$ & $\begin{array}{l}-0.001 \\
(0.001)\end{array}$ \\
\hline Time spend in unemployment in last 4 years (in 100 days) & $\begin{array}{c}-0.000^{* *} \\
(0.000)\end{array}$ & $\begin{array}{c}-0.000 \\
(0.000)\end{array}$ & $\begin{array}{l}-0.000 \\
(0.000)\end{array}$ \\
\hline Time spend in employment in last 4 years (in 100 days) & $\begin{array}{c}-0.001^{* * *} \\
(0.000)\end{array}$ & $\begin{array}{l}-0.000 \\
(0.000)\end{array}$ & $\begin{array}{r}0.000 \\
(0.000)\end{array}$ \\
\hline Employed 4 years before entry into unemployment & $\begin{array}{c}0.011^{* * *} \\
(0.001)\end{array}$ & $\begin{array}{c}-0.001 \\
(0.001)\end{array}$ & $\begin{array}{l}-0.000 \\
(0.001)\end{array}$ \\
\hline Daily income 4 years before entry into unemployment & $\begin{array}{c}-0.000^{* * *} \\
(0.000)\end{array}$ & $\begin{array}{r}0.000 \\
(0.000)\end{array}$ & $\begin{array}{l}-0.000 \\
(0.000)\end{array}$ \\
\hline Total income in last 4 years (in $€ 10,000$ ) & $\begin{array}{c}0.001^{* * *} \\
(0.000)\end{array}$ & $\begin{array}{l}-0.000 \\
(0.000)\end{array}$ & $\begin{array}{l}-0.000 \\
(0.000)\end{array}$ \\
\hline
\end{tabular}


Continued from previous page.

No. of employers in last 10 years

No. of programs in last 10 years

Months in program in last 10 years

Months in unemployment in last 10 years

Time spend in employment in last 10 years (in 100 days)

No. of unemployment spells in last 10 years

Total time with last employer in last 10 years

Total income in last 10 years (in $€ 10,000$ )

Duration of last employment

Information on current unemployment spell

Remaining benefit entitlement (Ref.: 0-3 months)

4-6 months

7-9 months

10-12 months

more than 12 months

Any form of non-compliance with benefit conditions

Daily unemployment benfits (in €100)

Year of entry $(=2006)$

Month of entry into unemployment (Ref.: Jan.-Mar.) Apr.-Jun.

Jul.-Sep.

Oct.-Dec.

Any vacancy referral

Participation in other program during current UE spell

LEA fixed effects

No. of observations

$\mathrm{R}^{2}$

Adjusted $\mathrm{R}^{2}$

\begin{tabular}{|c|c|c|}
\hline $\begin{array}{c}-0.001^{* * *} \\
(0.000)\end{array}$ & $\begin{array}{l}-0.000 \\
(0.000)\end{array}$ & $\begin{array}{c}0.000^{* *} \\
(0.000)\end{array}$ \\
\hline $\begin{array}{c}0.002^{* * *} \\
(0.001)\end{array}$ & $\begin{array}{l}-0.000 \\
(0.000)\end{array}$ & $\begin{array}{c}-0.001^{* *} \\
(0.000)\end{array}$ \\
\hline $\begin{array}{c}0.005^{* * *} \\
(0.001)\end{array}$ & $\begin{array}{c}0.002 \\
(0.001)\end{array}$ & $\begin{array}{r}0.001 \\
(0.001)\end{array}$ \\
\hline $\begin{array}{l}-0.000 \\
(0.000)\end{array}$ & $\begin{array}{l}-0.000 \\
(0.000)\end{array}$ & $\begin{array}{l}-0.000 \\
(0.000)\end{array}$ \\
\hline $\begin{array}{c}0.001^{* * *} \\
(0.000)\end{array}$ & $\begin{array}{r}0.000 \\
(0.000)\end{array}$ & $\begin{array}{l}-0.000 \\
(0.000)\end{array}$ \\
\hline $\begin{array}{c}0.002^{* * *} \\
(0.000)\end{array}$ & $\begin{array}{r}0.000 \\
(0.000)\end{array}$ & $\begin{array}{l}-0.000 \\
(0.000)\end{array}$ \\
\hline $\begin{array}{l}0.000^{* *} \\
(0.000)\end{array}$ & $\begin{array}{r}0.000 \\
(0.000)\end{array}$ & $\begin{array}{r}0.000 \\
(0.000)\end{array}$ \\
\hline $\begin{array}{c}-0.001^{* * *} \\
(0.000)\end{array}$ & $\begin{array}{l}-0.000 \\
(0.000)\end{array}$ & $\begin{array}{l}0.000^{*} \\
(0.000)\end{array}$ \\
\hline $\begin{array}{c}-0.000^{* * *} \\
(0.000)\end{array}$ & $\begin{array}{r}0.000 \\
(0.000)\end{array}$ & $\begin{array}{c}0.000 \\
(0.000)\end{array}$ \\
\hline $\begin{array}{c}0.011^{* * *} \\
(0.002)\end{array}$ & $\begin{array}{c}0.003^{* * *} \\
(0.001)\end{array}$ & $\begin{array}{r}0.001 \\
(0.001)\end{array}$ \\
\hline $\begin{array}{c}0.015^{* * *} \\
(0.001)\end{array}$ & $\begin{array}{c}0.005^{* * *} \\
(0.001)\end{array}$ & $\begin{array}{c}0.003^{* * *} \\
(0.001)\end{array}$ \\
\hline $\begin{array}{c}0.015^{* * *} \\
(0.001)\end{array}$ & $\begin{array}{c}0.004^{* * *} \\
(0.001)\end{array}$ & $\begin{array}{c}0.002^{* * *} \\
(0.001)\end{array}$ \\
\hline $\begin{array}{c}0.017^{* * *} \\
(0.002)\end{array}$ & $\begin{array}{c}0.005^{* * *} \\
(0.001)\end{array}$ & $\begin{array}{l}0.002^{* *} \\
(0.001)\end{array}$ \\
\hline $\begin{array}{c}-0.005^{* * *} \\
(0.001)\end{array}$ & $\begin{array}{l}0.001^{* *} \\
(0.001)\end{array}$ & $\begin{array}{l}0.001^{* *} \\
(0.000)\end{array}$ \\
\hline $\begin{array}{c}-0.029^{* * *} \\
(0.004)\end{array}$ & $\begin{array}{c}-0.010^{* * *} \\
(0.003)\end{array}$ & $\begin{array}{c}-0.004^{* *} \\
(0.002)\end{array}$ \\
\hline $\begin{array}{c}-0.039^{* * *} \\
(0.001)\end{array}$ & $\begin{array}{c}-0.005^{* * *} \\
(0.001)\end{array}$ & $\begin{array}{c}-0.003^{* * *} \\
(0.000)\end{array}$ \\
\hline $\begin{array}{c}-0.006^{* * *} \\
(0.001)\end{array}$ & $\begin{array}{c}0.002^{* * *} \\
(0.001)\end{array}$ & $\begin{array}{c}0.000 \\
(0.000)\end{array}$ \\
\hline $\begin{array}{c}-0.003^{* * *} \\
(0.001)\end{array}$ & $\begin{array}{c}0.003^{* * *} \\
(0.001)\end{array}$ & $\begin{array}{l}0.001^{*} \\
(0.000)\end{array}$ \\
\hline $\begin{array}{c}0.001 \\
(0.001)\end{array}$ & $\begin{array}{c}0.003^{* * *} \\
(0.001)\end{array}$ & $\begin{array}{c}0.003^{* * *} \\
(0.000)\end{array}$ \\
\hline $\begin{array}{c}-0.002^{* * *} \\
(0.001)\end{array}$ & $\begin{array}{c}0.001 \\
(0.001)\end{array}$ & $\begin{array}{c}0.000 \\
(0.000)\end{array}$ \\
\hline \multirow[t]{2}{*}{$\begin{array}{c}-0.004^{* * *} \\
(0.001)\end{array}$} & $\begin{array}{c}0.000 \\
(0.001)\end{array}$ & $\begin{array}{c}0.000 \\
(0.000)\end{array}$ \\
\hline & 30397 & $\begin{array}{c}\checkmark \\
30397\end{array}$ \\
\hline $\begin{array}{c}30,397 \\
0.326\end{array}$ & $\begin{array}{c}30,091 \\
0.011\end{array}$ & 0.009 \\
\hline 0.325 & 0.008 & 0.007 \\
\hline
\end{tabular}

Note: OLS estimation. */**/** indicates significance at the $10 \% / 5 \% / 1 \%$-level. Standard errors are in parenthesis and clustered at the LEA-level. 


\begin{tabular}{|c|c|c|c|c|}
\hline & $\begin{array}{c}\begin{array}{c}\text { Log first } \\
\text { daily wage }\end{array} \\
(1)\end{array}$ & $\begin{array}{c}\begin{array}{c}\text { Log average } \\
\text { daily wage }\end{array} \\
(2)\end{array}$ & $\begin{array}{c}\begin{array}{c}\text { No. of } \\
\text { job quits }\end{array} \\
(3)\end{array}$ & $\begin{array}{c}\text { Employed } \\
\text { in } t_{u e+24} \\
(4)\end{array}$ \\
\hline Relocation assistance & $\begin{array}{c}0.138^{* * *} \\
(0.015)\end{array}$ & $\begin{array}{l}0.145^{* * *} \\
(0.014)\end{array}$ & $\begin{array}{c}-0.126^{* * *} \\
(0.041)\end{array}$ & $\begin{array}{c}0.018 \\
(0.019)\end{array}$ \\
\hline Age in years & $\begin{array}{c}-0.008^{* * *} \\
(0.002)\end{array}$ & $\begin{array}{c}-0.008^{* * *} \\
(0.002)\end{array}$ & $\begin{array}{c}0.008 \\
(0.007)\end{array}$ & $\begin{array}{c}0.004 \\
(0.003)\end{array}$ \\
\hline Age in years ${ }^{2}$ (div. by 100) & $\begin{array}{c}0.007^{* * *} \\
(0.003)\end{array}$ & $\begin{array}{c}0.006^{* *} \\
(0.003)\end{array}$ & $\begin{array}{l}-0.002 \\
(0.009)\end{array}$ & $\begin{array}{c}-0.010^{* *} \\
(0.004)\end{array}$ \\
\hline \multicolumn{5}{|l|}{ School leaving degree (Ref.: None) } \\
\hline Lower sec. degree & $\begin{array}{c}0.015^{* *} \\
(0.006)\end{array}$ & $\begin{array}{c}0.020^{* * *} \\
(0.007)\end{array}$ & $\begin{array}{l}-0.014 \\
(0.028)\end{array}$ & $\begin{array}{c}0.015 \\
(0.011)\end{array}$ \\
\hline Middle sec. degree & $\begin{array}{c}0.019^{* * *} \\
(0.007)\end{array}$ & $\begin{array}{c}0.031^{* * *} \\
(0.007)\end{array}$ & $\begin{array}{c}-0.056^{*} \\
(0.029)\end{array}$ & $\begin{array}{l}0.023^{*} \\
(0.012)\end{array}$ \\
\hline Upper sec. degree & $\begin{array}{c}0.066^{* * *} \\
(0.010)\end{array}$ & $\begin{array}{c}0.085^{* * *} \\
(0.010)\end{array}$ & $\begin{array}{c}-0.114^{* * *} \\
(0.032)\end{array}$ & $\begin{array}{l}0.023^{*} \\
(0.012)\end{array}$ \\
\hline \multicolumn{5}{|l|}{ Vocational degree (Ref.: None) } \\
\hline In-firm training & $\begin{array}{c}0.019^{* * *} \\
(0.005)\end{array}$ & $\begin{array}{c}0.023^{* * *} \\
(0.005)\end{array}$ & $\begin{array}{c}-0.078^{* * *} \\
(0.021)\end{array}$ & $\begin{array}{c}0.047^{* * *} \\
(0.008)\end{array}$ \\
\hline External training & $\begin{array}{c}0.020^{* *} \\
(0.008)\end{array}$ & $\begin{array}{c}0.031^{* * *} \\
(0.008)\end{array}$ & $\begin{array}{c}-0.103^{* * *} \\
(0.030)\end{array}$ & $\begin{array}{c}0.073^{* * *} \\
(0.013)\end{array}$ \\
\hline Technical college education & $\begin{array}{c}0.008 \\
(0.016)\end{array}$ & $\begin{array}{c}0.024 \\
(0.015)\end{array}$ & $\begin{array}{c}-0.196^{* * *} \\
(0.045)\end{array}$ & $\begin{array}{c}0.048^{* *} \\
(0.020)\end{array}$ \\
\hline University degree & $\begin{array}{c}0.113^{* * *} \\
(0.012)\end{array}$ & $\begin{array}{c}0.135^{* * *} \\
(0.012)\end{array}$ & $\begin{array}{c}-0.092^{* * *} \\
(0.032)\end{array}$ & $\begin{array}{c}0.065^{* * *} \\
(0.014)\end{array}$ \\
\hline Children & $\begin{array}{c}0.011^{* * *} \\
(0.003)\end{array}$ & $\begin{array}{c}0.012^{* * *} \\
(0.002)\end{array}$ & $\begin{array}{l}-0.002 \\
(0.011)\end{array}$ & $\begin{array}{c}0.007 \\
(0.004)\end{array}$ \\
\hline Children $\leq 3$ years & $\begin{array}{c}-0.018^{* *} \\
(0.009)\end{array}$ & $\begin{array}{c}-0.021^{* * *} \\
(0.008)\end{array}$ & $\begin{array}{c}0.035 \\
(0.030)\end{array}$ & $\begin{array}{c}-0.032^{* * *} \\
(0.012)\end{array}$ \\
\hline Children $\leq 10$ years & $\begin{array}{l}-0.006 \\
(0.005)\end{array}$ & $\begin{array}{c}-0.012^{* *} \\
(0.005)\end{array}$ & $\begin{array}{l}0.000 \\
(0.024)\end{array}$ & $\begin{array}{l}-0.013 \\
(0.009)\end{array}$ \\
\hline Married & $\begin{array}{c}0.005 \\
(0.004)\end{array}$ & $\begin{array}{c}0.005 \\
(0.004)\end{array}$ & $\begin{array}{c}-0.032^{* *} \\
(0.014)\end{array}$ & $\begin{array}{c}0.025^{* * *} \\
(0.007)\end{array}$ \\
\hline Lone parent & $\begin{array}{c}-0.035^{* *} \\
(0.016)\end{array}$ & $\begin{array}{l}-0.020 \\
(0.016)\end{array}$ & $\begin{array}{c}0.018 \\
(0.059)\end{array}$ & $\begin{array}{l}-0.002 \\
(0.025)\end{array}$ \\
\hline Health problems & $\begin{array}{l}-0.020^{* * *} \\
(0.006)\end{array}$ & $\begin{array}{l}-0.030^{* * *} \\
(0.005)\end{array}$ & $\begin{array}{l}-0.019 \\
(0.023)\end{array}$ & $\begin{array}{c}-0.028^{* * *} \\
(0.009)\end{array}$ \\
\hline Migration background & $\begin{array}{c}-0.012^{* *} \\
(0.005)\end{array}$ & $\begin{array}{c}-0.018^{* * *} \\
(0.005)\end{array}$ & $\begin{array}{c}0.098^{* * *} \\
(0.021)\end{array}$ & $\begin{array}{c}-0.044^{* * *} \\
(0.008)\end{array}$ \\
\hline Professional qualification & $\begin{array}{c}0.036^{* * *} \\
(0.004)\end{array}$ & $\begin{array}{c}0.037^{* * *} \\
(0.003)\end{array}$ & $\begin{array}{c}-0.054^{* * *} \\
(0.010)\end{array}$ & $\begin{array}{c}0.005 \\
(0.004)\end{array}$ \\
\hline Any professional experience & $\begin{array}{c}-0.011^{* *} \\
(0.005)\end{array}$ & $\begin{array}{c}-0.016^{* * *} \\
(0.005)\end{array}$ & $\begin{array}{c}0.060^{* * *} \\
(0.017)\end{array}$ & $\begin{array}{c}-0.020^{* * *} \\
(0.007)\end{array}$ \\
\hline \multicolumn{5}{|l|}{ Labor market history } \\
\hline Share of jobs involve commuting in last 5 years & $\begin{array}{c}0.019^{* * *} \\
(0.005)\end{array}$ & $\begin{array}{c}0.028^{* * *} \\
(0.004)\end{array}$ & $\begin{array}{c}-0.100^{* * *} \\
(0.016)\end{array}$ & $\begin{array}{c}0.002 \\
(0.007)\end{array}$ \\
\hline Previous participation in mobility program & $\begin{array}{c}-0.023^{* * *} \\
(0.005)\end{array}$ & $\begin{array}{c}-0.013^{* *} \\
(0.005)\end{array}$ & $\begin{array}{l}-0.027 \\
(0.029)\end{array}$ & $\begin{array}{l}-0.001 \\
(0.011)\end{array}$ \\
\hline \multicolumn{5}{|c|}{ Last contact to employment agency (Ref.: more than 3 months ago) } \\
\hline $2-3$ months ago & $\begin{array}{c}0.012 \\
(0.019)\end{array}$ & $\begin{array}{c}0.007 \\
(0.020)\end{array}$ & $\begin{array}{l}-0.007 \\
(0.065)\end{array}$ & $\begin{array}{c}0.026 \\
(0.028)\end{array}$ \\
\hline 1-2 months ago & $\begin{array}{c}0.021 \\
(0.019)\end{array}$ & $\begin{array}{c}0.010 \\
(0.019)\end{array}$ & $\begin{array}{c}0.008 \\
(0.062)\end{array}$ & $\begin{array}{c}0.028 \\
(0.027)\end{array}$ \\
\hline within last month & $\begin{array}{l}-0.002 \\
(0.018)\end{array}$ & $\begin{array}{l}-0.005 \\
(0.018)\end{array}$ & $\begin{array}{c}0.057 \\
(0.058)\end{array}$ & $\begin{array}{c}0.017 \\
(0.025)\end{array}$ \\
\hline no previous contact & $\begin{array}{c}0.026 \\
(0.018)\end{array}$ & $\begin{array}{c}0.026 \\
(0.017)\end{array}$ & $\begin{array}{c}0.028 \\
(0.062)\end{array}$ & $\begin{array}{c}0.021 \\
(0.026)\end{array}$ \\
\hline \multicolumn{5}{|c|}{ Occupational group of previous job (Ref.: Agriculture) } \\
\hline Manufacturing & $\begin{array}{c}0.016^{* *} \\
(0.006)\end{array}$ & $\begin{array}{c}0.027^{* * *} \\
(0.006)\end{array}$ & $\begin{array}{c}-0.239^{* * *} \\
(0.039)\end{array}$ & $\begin{array}{c}0.060^{* * *} \\
(0.013)\end{array}$ \\
\hline Technical occupation & $\begin{array}{c}0.034^{* * *} \\
(0.012)\end{array}$ & $\begin{array}{c}0.060^{* * *} \\
(0.011)\end{array}$ & $\begin{array}{c}-0.266^{* * *} \\
(0.046)\end{array}$ & $\begin{array}{c}0.083^{* * *} \\
(0.016)\end{array}$ \\
\hline Service & $\begin{array}{c}0.018^{* *} \\
(0.007)\end{array}$ & $\begin{array}{c}0.034^{* * *} \\
(0.007)\end{array}$ & $\begin{array}{c}-0.250^{* * *} \\
(0.038)\end{array}$ & $\begin{array}{c}0.067^{* * * *} \\
(0.013)\end{array}$ \\
\hline Other & $\begin{array}{l}-0.010 \\
(0.021)\end{array}$ & $\begin{array}{c}0.025 \\
(0.021)\end{array}$ & $\begin{array}{c}-0.205^{* *} \\
(0.083)\end{array}$ & $\begin{array}{c}0.058 \\
(0.037)\end{array}$ \\
\hline
\end{tabular}


Continued from previous page.

Last job was full-time employment

Log last daily income

Reason for termination of last job: Laid off by employer

Months in employment in year

t-1

t-2

t-3

Months in program in year

t-1

$\mathrm{t}-2$

$\mathrm{t}-3$

Months in unemployment in year

t-1

$\mathrm{t}-2$

t-3

Log average daily wage in year

t-1

$\mathrm{t}-2$

$\mathrm{t}-3$

No. of employers in last 24 months

No. of programs in last 4 years

Months in program in last 4 years

Time spend in unemployment in last 4 years (in 100 days)

Time spend in employment in last 4 years (in 100 days)

Employed 4 years before entry into unemployment

Daily income 4 years before entry into unemployment

Total income in last 4 years (in $€ 10,000$ )

No. of employers in last 10 years

No. of programs in last 10 years

Months in program in last 10 years

Months in unemployment in last 10 years

Time spend in employment in last 10 years (in 100 days)

No. of unemployment spells in last 10 years

Total time with last employer in last 10 years

Total income in last 10 years (in $€ 10,000$ )

Duration of last employment

\begin{tabular}{|c|c|c|c|}
\hline $\begin{array}{c}0.052^{* * *} \\
(0.017)\end{array}$ & $\begin{array}{c}0.040^{* *} \\
(0.018)\end{array}$ & $\begin{array}{l}-0.081 \\
(0.075)\end{array}$ & $\begin{array}{l}-0.002 \\
(0.024)\end{array}$ \\
\hline $\begin{array}{c}0.163^{* * *} \\
(0.014)\end{array}$ & $\begin{array}{c}0.142^{* * *} \\
(0.014)\end{array}$ & $\begin{array}{l}-0.041 \\
(0.043)\end{array}$ & $\begin{array}{l}-0.003 \\
(0.017)\end{array}$ \\
\hline $\begin{array}{c}-0.045^{* * *} \\
(0.007)\end{array}$ & $\begin{array}{c}-0.031^{* * *} \\
(0.007)\end{array}$ & $\begin{array}{c}-0.069^{* * *} \\
(0.025)\end{array}$ & $\begin{array}{c}0.032^{* * *} \\
(0.012)\end{array}$ \\
\hline $\begin{array}{c}0.003^{* * *} \\
(0.001)\end{array}$ & $\begin{array}{c}0.002^{* * *} \\
(0.001)\end{array}$ & $\begin{array}{c}-0.047^{* * *} \\
(0.003)\end{array}$ & $\begin{array}{c}0.014^{* * *} \\
(0.001)\end{array}$ \\
\hline $\begin{array}{l}-0.001 \\
0.001)\end{array}$ & $\begin{array}{r}-0.000 \\
(0.001)\end{array}$ & $\begin{array}{r}-0.004 \\
(0.003)\end{array}$ & $\begin{array}{c}0.004^{* * *} \\
(0.001)\end{array}$ \\
\hline $\begin{array}{c}-0.002^{* * *} \\
(0.001)\end{array}$ & $\begin{array}{c}-0.002^{* *} \\
(0.001)\end{array}$ & $\begin{array}{c}-0.017^{* * *} \\
(0.003)\end{array}$ & $\begin{array}{c}0.003^{* * *} \\
(0.001)\end{array}$ \\
\hline $\begin{array}{c}0.001 \\
(0.003)\end{array}$ & $\begin{array}{c}0.004 \\
(0.003)\end{array}$ & $\begin{array}{c}-0.057^{* * *} \\
(0.011)\end{array}$ & $\begin{array}{c}0.011^{* *} \\
(0.005)\end{array}$ \\
\hline $\begin{array}{c}0.002 \\
(0.002)\end{array}$ & $\begin{array}{c}0.002 \\
(0.002)\end{array}$ & $\begin{array}{r}-0.009 \\
(0.007)\end{array}$ & $\begin{array}{l}0.005^{*} \\
(0.003)\end{array}$ \\
\hline-0.001 & -0.000 & -0.001 & 0.000 \\
\hline (0.001) & $(0.001)$ & $(0.006)$ & $(0.002)$ \\
\hline $\begin{array}{l}-0.005 \\
(0.004)\end{array}$ & $\begin{array}{l}-0.002 \\
(0.003)\end{array}$ & $\begin{array}{l}-0.015 \\
(0.014)\end{array}$ & $\begin{array}{l}-0.003 \\
(0.006)\end{array}$ \\
\hline 0.002 & 0.002 & $-0.014^{*}$ & $0.007^{* *}$ \\
\hline (0.002) & $(0.002)$ & $(0.008)$ & (0.003) \\
\hline $\begin{array}{l}-0.001 \\
(0.002)\end{array}$ & $\begin{array}{l}-0.001 \\
(0.002)\end{array}$ & $\begin{array}{c}0.002 \\
(0.007)\end{array}$ & $\begin{array}{l}-0.000 \\
(0.003)\end{array}$ \\
\hline $\begin{array}{c}0.356^{* * *} \\
(0.021)\end{array}$ & $\begin{array}{c}0.349^{* * *} \\
(0.020)\end{array}$ & $\begin{array}{c}-0.094^{* *} \\
(0.047)\end{array}$ & $\begin{array}{c}0.046^{* *} \\
(0.020)\end{array}$ \\
\hline $0.003^{* * *}$ & $0.001^{*}$ & 0.003 & -0.002 \\
\hline $0.002^{* * *}$ & $0.002^{* *}$ & $0.018^{* * *}$ & $\begin{array}{l}(0.001) \\
-0.000\end{array}$ \\
\hline$(0.001)$ & $(0.001)$ & $(0.003)$ & $(0.001)$ \\
\hline-0.002 & 0.003 & $0.031^{* * *}$ & $0.010^{* * *}$ \\
\hline$(0.002)$ & $(0.002)$ & $(0.010)$ & $(0.004)$ \\
\hline $0.008^{*}$ & 0.004 & -0.001 & 0.000 \\
\hline$(0.004)$ & $(0.004)$ & $(0.018)$ & $(0.007)$ \\
\hline$-0.021^{* *}$ & -0.006 & -0.005 & -0.005 \\
\hline$(0.008)$ & (0.008) & $(0.030)$ & $(0.014)$ \\
\hline 0.000 & -0.000 & $0.008^{* * *}$ & -0.002 \\
\hline$(0.001)$ & $(0.001)$ & $(0.003)$ & $(0.002)$ \\
\hline $\begin{array}{c}0.001 \\
(0.001)\end{array}$ & $\begin{array}{l}-0.000 \\
(0.001)\end{array}$ & $\begin{array}{c}0.004 \\
(0.003)\end{array}$ & $\begin{array}{c}-0.002^{*} \\
(0.001)\end{array}$ \\
\hline$-0.090^{* * *}$ & $-0.092^{* * *}$ & -0.001 & 0.018 \\
\hline$(0.008)$ & $(0.008)$ & $(0.027)$ & $(0.011)$ \\
\hline $0.001^{* * *}$ & $0.001^{* * *}$ & $-0.002^{* * *}$ & $0.000^{* *}$ \\
\hline$(0.000)$ & $(0.000)$ & $(0.000)$ & (0.000) \\
\hline $\begin{array}{c}0.000 \\
(0.001)\end{array}$ & $\begin{array}{c}0.001 \\
(0.001)\end{array}$ & $\begin{array}{r}-0.003 \\
(0.004)\end{array}$ & $\begin{array}{l}-0.001 \\
(0.002)\end{array}$ \\
\hline$-0.003^{* * *}$ & $-0.002^{* * *}$ & $0.010^{* *}$ & -0.001 \\
\hline$(0.001)$ & $(0.001)$ & $(0.005)$ & $(0.002)$ \\
\hline$-0.007^{* *}$ & $-0.008^{* * *}$ & -0.013 & -0.001 \\
\hline$(0.003)$ & $(0.003)$ & $(0.013)$ & (0.005) \\
\hline-0.005 & -0.004 & $-0.048^{*}$ & $0.032^{* * *}$ \\
\hline$(0.006)$ & $(0.006)$ & $(0.028)$ & (0.011) \\
\hline-0.000 & -0.000 & -0.000 & 0.000 \\
\hline$(0.000)$ & $(0.000)$ & $(0.000)$ & $(0.000)$ \\
\hline$-0.002^{* * *}$ & $-0.001^{* * *}$ & -0.001 & $0.001^{* * *}$ \\
\hline$(0.000)$ & $(0.000)$ & $(0.001)$ & $(0.000)$ \\
\hline $\begin{array}{c}0.007^{* * *} \\
(0.001)\end{array}$ & $0.004^{* * *}$ & $0.064^{* * *}$ & $-0.013^{* * *}$ \\
\hline (0.001) & $(0.001)$ & $(0.004)$ & $(0.001)$ \\
\hline 0.000 & 0.000 & -0.000 & -0.000 \\
\hline$(0.000)$ & $(0.000)$ & $(0.000)$ & $(0.000)$ \\
\hline $0.002^{* *}$ & $0.002^{* *}$ & 0.002 & -0.001 \\
\hline$(0.001)$ & $(0.001)$ & $(0.002)$ & $(0.001)$ \\
\hline$-0.002^{* * *}$ & $-0.002^{* * *}$ & -0.001 & 0.000 \\
\hline$(0.001)$ & (0.001) & $(0.002)$ & (0.001) \\
\hline
\end{tabular}

Continued on next page. 
Continued from previous page.

\begin{tabular}{|c|c|c|c|c|}
\hline \multicolumn{5}{|l|}{ Information on current unemployment spell } \\
\hline \multicolumn{5}{|l|}{ Duration of initial unemployment spell (Ref.: 1-3 months) } \\
\hline 4-6 months & $\begin{array}{c}-0.025^{* * *} \\
(0.003)\end{array}$ & $\begin{array}{c}-0.029^{* * *} \\
(0.003)\end{array}$ & $\begin{array}{c}0.163^{* * *} \\
(0.016)\end{array}$ & $\begin{array}{c}-0.016^{* *} \\
(0.007)\end{array}$ \\
\hline 7-9 months & $\begin{array}{c}-0.068^{* * *} \\
(0.006)\end{array}$ & $\begin{array}{c}-0.068^{* * *} \\
(0.005)\end{array}$ & $\begin{array}{c}0.150^{* * * *} \\
(0.025)\end{array}$ & $\begin{array}{c}-0.018^{*} \\
(0.010)\end{array}$ \\
\hline 10-12 months & $\begin{array}{c}-0.124^{* * * *} \\
(0.008)\end{array}$ & $\begin{array}{c}-0.109^{* * *} \\
(0.008)\end{array}$ & $\begin{array}{c}0.148^{* * *} \\
(0.027)\end{array}$ & $\begin{array}{c}-0.060^{* * *} \\
(0.013)\end{array}$ \\
\hline more than 12 months & $\begin{array}{c}-0.129^{* * *} \\
(0.008)\end{array}$ & $\begin{array}{c}-0.122^{* * *} \\
(0.007)\end{array}$ & $\begin{array}{c}0.204^{* * *} \\
(0.026)\end{array}$ & $\begin{array}{c}-0.117^{* * *} \\
(0.010)\end{array}$ \\
\hline \multicolumn{5}{|l|}{ Remaining benefit entitlement (Ref.: 0-3 months) } \\
\hline 4-6 months & $\begin{array}{c}-0.041^{* * *} \\
(0.007)\end{array}$ & $\begin{array}{c}-0.038^{* * *} \\
(0.007)\end{array}$ & $\begin{array}{c}0.036 \\
(0.030)\end{array}$ & $\begin{array}{c}0.005 \\
(0.013)\end{array}$ \\
\hline 7-9 months & $\begin{array}{c}-0.032^{* * *} \\
(0.007)\end{array}$ & $\begin{array}{c}-0.032^{* * *} \\
(0.006)\end{array}$ & $\begin{array}{c}0.079^{* * *} \\
(0.029)\end{array}$ & $\begin{array}{c}0.007 \\
(0.013)\end{array}$ \\
\hline 10-12 months & $\begin{array}{c}-0.036^{* * *} \\
(0.006)\end{array}$ & $\begin{array}{c}-0.031^{* * *} \\
(0.005)\end{array}$ & $\begin{array}{c}0.049^{* *} \\
(0.023)\end{array}$ & $\begin{array}{c}0.008 \\
(0.011)\end{array}$ \\
\hline more than 12 months & $\begin{array}{c}-0.024^{* * *} \\
(0.008)\end{array}$ & $\begin{array}{c}-0.023^{* * *} \\
(0.007)\end{array}$ & $\begin{array}{c}0.099^{* * *} \\
(0.033)\end{array}$ & $\begin{array}{l}-0.018 \\
(0.014)\end{array}$ \\
\hline Any form of non-compliance with benefit conditions & $\begin{array}{c}-0.035^{* * *} \\
(0.004)\end{array}$ & $\begin{array}{c}-0.043^{* * *} \\
(0.005)\end{array}$ & $\begin{array}{c}0.408^{* * *} \\
(0.016)\end{array}$ & $\begin{array}{c}-0.115^{* * *} \\
(0.008)\end{array}$ \\
\hline Daily unemployment benfits (in $€ 100$ ) & $\begin{array}{c}0.130^{* * *} \\
(0.018)\end{array}$ & $\begin{array}{c}0.127^{* * *} \\
(0.016)\end{array}$ & $\begin{array}{c}0.196^{* * *} \\
(0.064)\end{array}$ & $\begin{array}{c}-0.076^{* *} \\
(0.031)\end{array}$ \\
\hline Year of entry $(=2006)$ & $\begin{array}{c}0.013^{* *} \\
(0.006)\end{array}$ & $\begin{array}{c}0.010 \\
(0.007)\end{array}$ & $\begin{array}{l}0.049^{*} \\
(0.026)\end{array}$ & $\begin{array}{c}-0.033^{\text {*** }} \\
(0.009)\end{array}$ \\
\hline \multicolumn{5}{|l|}{ Month of entry into unemployment (Ref.: Jan.-Mar.) } \\
\hline Apr.-Jun. & $\begin{array}{c}-0.014^{* *} \\
(0.006)\end{array}$ & $\begin{array}{l}-0.001 \\
(0.005)\end{array}$ & $\begin{array}{l}-0.004 \\
(0.018)\end{array}$ & $\begin{array}{c}0.002 \\
(0.006)\end{array}$ \\
\hline Jul.-Sep. & $\begin{array}{c}-0.017^{* * *} \\
(0.005)\end{array}$ & $\begin{array}{l}-0.003 \\
(0.005)\end{array}$ & $\begin{array}{l}0.037^{*} \\
(0.019)\end{array}$ & $\begin{array}{l}-0.005 \\
(0.008)\end{array}$ \\
\hline Oct.-Dec. & $\begin{array}{l}0.008^{*} \\
(0.004)\end{array}$ & $\begin{array}{c}0.012^{* * *} \\
(0.004)\end{array}$ & $\begin{array}{c}0.123^{* * *} \\
(0.020)\end{array}$ & $\begin{array}{c}-0.055^{\text {*** }} \\
(0.008)\end{array}$ \\
\hline Any vacancy referral & $\begin{array}{l}-0.025^{* * *} \\
(0.003)\end{array}$ & $\begin{array}{c}-0.014^{* * *} \\
(0.003)\end{array}$ & $\begin{array}{c}-0.034^{* *} \\
(0.014)\end{array}$ & $\begin{array}{c}0.019^{* * *} \\
(0.006)\end{array}$ \\
\hline Participation in other ALMP program & $\begin{array}{l}-0.007 \\
(0.006)\end{array}$ & $\begin{array}{c}0.002 \\
(0.006)\end{array}$ & $\begin{array}{c}-0.131^{* * *} \\
(0.019)\end{array}$ & $\begin{array}{c}0.032^{* * *} \\
(0.008)\end{array}$ \\
\hline \multicolumn{5}{|l|}{ Regional characteristics } \\
\hline Living in East-Germany & $\begin{array}{c}-0.074^{* * *} \\
(0.008)\end{array}$ & $\begin{array}{c}-0.091^{* * *} \\
(0.008)\end{array}$ & $\begin{array}{c}0.115^{* * *} \\
(0.027)\end{array}$ & $\begin{array}{l}-0.006 \\
(0.010)\end{array}$ \\
\hline Local unemployment rate & $\begin{array}{c}0.018 \\
(0.082)\end{array}$ & $\begin{array}{l}-0.047 \\
(0.076)\end{array}$ & $\begin{array}{c}0.376 \\
(0.325)\end{array}$ & $\begin{array}{l}-0.158 \\
(0.099)\end{array}$ \\
\hline GDP per capita in $€ 10000$ & $\begin{array}{c}0.001 \\
(0.003)\end{array}$ & $\begin{array}{l}-0.000 \\
(0.003)\end{array}$ & $\begin{array}{c}0.004 \\
(0.008)\end{array}$ & $\begin{array}{c}0.003 \\
(0.002)\end{array}$ \\
\hline Local vacancy rate & $\begin{array}{c}0.053 \\
(0.091)\end{array}$ & $\begin{array}{l}0.104 \\
(0.095)\end{array}$ & $\begin{array}{l}-0.032 \\
(0.317)\end{array}$ & $\begin{array}{c}0.008 \\
(0.083)\end{array}$ \\
\hline \multicolumn{5}{|l|}{ Share of working population in (Ref.: Agriculture) } \\
\hline Industry sector & $\begin{array}{l}-0.000 \\
(0.001)\end{array}$ & $\begin{array}{c}0.000 \\
(0.001)\end{array}$ & $\begin{array}{c}-0.005^{* *} \\
(0.002)\end{array}$ & $\begin{array}{l}-0.000 \\
(0.001)\end{array}$ \\
\hline Service sector & $\begin{array}{l}-0.001 \\
(0.001)\end{array}$ & $\begin{array}{l}-0.000 \\
(0.001)\end{array}$ & $\begin{array}{c}-0.005^{* * *} \\
(0.002)\end{array}$ & $\begin{array}{l}-0.001 \\
(0.001)\end{array}$ \\
\hline No. of observations & 30,397 & 30,397 & 30,397 & 30,397 \\
\hline
\end{tabular}

Note: OLS estimation of the outcome equation. ${ }^{* * *} /{ }^{* *} /{ }^{*}$ indicate statistically significance at the $1 \% / 5 \% / 10 \%$-level. Standard errors are in parenthesis and clustered at LEA-level. 
Table B.4: Baseline Results: IV Estimation with LEA Fixed Effects

\begin{tabular}{|c|c|c|c|c|}
\hline & $\begin{array}{c}\text { Log first } \\
\text { daily wage } \\
(1)\end{array}$ & $\begin{array}{c}\text { Log average } \\
\text { daily wage }\end{array}$ & $\begin{array}{c}\begin{array}{c}\text { No. of } \\
\text { job quits }\end{array} \\
(3)\end{array}$ & $\begin{array}{c}\text { Employed } \\
\text { in } t_{u e+24} \\
(4)\end{array}$ \\
\hline Relocation assistance & $\begin{array}{c}0.245^{* * *} \\
(0.088)\end{array}$ & $\begin{array}{c}0.163^{* *} \\
(0.079)\end{array}$ & $\begin{array}{c}-1.027^{* * *} \\
(0.309)\end{array}$ & $\begin{array}{c}0.243^{* *} \\
(0.100)\end{array}$ \\
\hline Age in years & $\begin{array}{c}-0.008^{* * *} \\
(0.002)\end{array}$ & $\begin{array}{c}-0.008^{* * *} \\
(0.002)\end{array}$ & $\begin{array}{c}0.010 \\
(0.007)\end{array}$ & $\begin{array}{c}0.004 \\
(0.003)\end{array}$ \\
\hline Age in years ${ }^{2}$ (div. by 100) & $\begin{array}{c}0.008^{* * *} \\
(0.003)\end{array}$ & $\begin{array}{c}0.006^{* *} \\
(0.003)\end{array}$ & $\begin{array}{l}-0.005 \\
(0.009)\end{array}$ & $\begin{array}{c}-0.009^{* *} \\
(0.004)\end{array}$ \\
\hline \multicolumn{5}{|l|}{ School leaving degree (Ref.: None) } \\
\hline Lower sec. degree & $\begin{array}{c}0.014^{* *} \\
(0.006)\end{array}$ & $\begin{array}{c}0.019^{* * *} \\
(0.007)\end{array}$ & $\begin{array}{l}-0.015 \\
(0.028)\end{array}$ & $\begin{array}{c}0.015 \\
(0.011)\end{array}$ \\
\hline Middle sec. degree & $\begin{array}{c}0.019^{* * *} \\
(0.007)\end{array}$ & $\begin{array}{c}0.031^{* * *} \\
(0.007)\end{array}$ & $\begin{array}{c}-0.056^{*} \\
(0.029)\end{array}$ & $\begin{array}{l}0.021^{*} \\
(0.012)\end{array}$ \\
\hline Upper sec. degree & $\begin{array}{c}0.064^{* * *} \\
(0.010)\end{array}$ & $\begin{array}{c}0.084^{* * *} \\
(0.010)\end{array}$ & $\begin{array}{c}-0.094^{* * *} \\
(0.033)\end{array}$ & $\begin{array}{c}0.016 \\
(0.013)\end{array}$ \\
\hline \multicolumn{5}{|l|}{ Vocational degree (Ref.: None) } \\
\hline In-firm training & $\begin{array}{c}0.020^{* * *} \\
(0.005)\end{array}$ & $\begin{array}{c}0.024^{* * *} \\
(0.005)\end{array}$ & $\begin{array}{c}-0.088^{* * *} \\
(0.021)\end{array}$ & $\begin{array}{c}0.050^{* * *} \\
(0.008)\end{array}$ \\
\hline External training & $\begin{array}{c}0.019^{* *} \\
(0.008)\end{array}$ & $\begin{array}{c}0.031^{* * *} \\
(0.008)\end{array}$ & $\begin{array}{c}-0.104^{* * *} \\
(0.030)\end{array}$ & $\begin{array}{c}0.073^{* * *} \\
(0.013)\end{array}$ \\
\hline Technical college education & $\begin{array}{c}0.008 \\
(0.016)\end{array}$ & $\begin{array}{c}0.024 \\
(0.015)\end{array}$ & $\begin{array}{c}-0.189^{* * *} \\
(0.048)\end{array}$ & $\begin{array}{c}0.045^{* *} \\
(0.020)\end{array}$ \\
\hline University degree & $\begin{array}{c}0.111^{* * *} \\
(0.013)\end{array}$ & $\begin{array}{c}0.134^{* * *} \\
(0.013)\end{array}$ & $\begin{array}{c}-0.084^{* *} \\
(0.033)\end{array}$ & $\begin{array}{c}0.063^{* * *} \\
(0.014)\end{array}$ \\
\hline Children & $\begin{array}{c}0.011^{* * *} \\
(0.003)\end{array}$ & $\begin{array}{c}0.012^{* * *} \\
(0.002)\end{array}$ & $\begin{array}{l}-0.002 \\
(0.011)\end{array}$ & $\begin{array}{c}0.006 \\
(0.004)\end{array}$ \\
\hline Children $\leq 3$ years & $\begin{array}{c}-0.018^{* *} \\
(0.009)\end{array}$ & $\begin{array}{c}-0.021^{* * * *} \\
(0.008)\end{array}$ & $\begin{array}{c}0.036 \\
(0.030)\end{array}$ & $\begin{array}{c}-0.032^{* * *} \\
(0.012)\end{array}$ \\
\hline Children $\leq 10$ years & $\begin{array}{l}-0.005 \\
(0.005)\end{array}$ & $\begin{array}{c}-0.011^{* *} \\
(0.005)\end{array}$ & $\begin{array}{l}-0.002 \\
(0.025)\end{array}$ & $\begin{array}{l}-0.012 \\
(0.009)\end{array}$ \\
\hline Married & $\begin{array}{c}0.005 \\
(0.004)\end{array}$ & $\begin{array}{l}0.006 \\
(0.004)\end{array}$ & $\begin{array}{c}-0.037^{* * *} \\
(0.014)\end{array}$ & $\begin{array}{c}0.026^{* * *} \\
(0.007)\end{array}$ \\
\hline Lone parent & $\begin{array}{c}-0.035^{* *} \\
(0.016)\end{array}$ & $\begin{array}{l}-0.021 \\
(0.016)\end{array}$ & $\begin{array}{c}0.008 \\
(0.058)\end{array}$ & $\begin{array}{c}0.001 \\
(0.026)\end{array}$ \\
\hline Health problems & $\begin{array}{c}-0.020^{* * *} \\
(0.006)\end{array}$ & $\begin{array}{c}-0.030^{* * *} \\
(0.006)\end{array}$ & $\begin{array}{l}-0.019 \\
(0.023)\end{array}$ & $\begin{array}{c}-0.028^{* * *} \\
(0.010)\end{array}$ \\
\hline Migration background & $\begin{array}{c}-0.012^{* *} \\
(0.005)\end{array}$ & $\begin{array}{c}-0.018^{* * *} \\
(0.005)\end{array}$ & $\begin{array}{c}0.097^{* * *} \\
(0.022)\end{array}$ & $\begin{array}{c}-0.041^{* * *} \\
(0.008)\end{array}$ \\
\hline Professional qualification & $\begin{array}{c}0.036^{* * *} \\
(0.004)\end{array}$ & $\begin{array}{c}0.038^{* * *} \\
(0.003)\end{array}$ & $\begin{array}{c}-0.051^{* * *} \\
(0.010)\end{array}$ & $\begin{array}{c}0.004 \\
(0.004)\end{array}$ \\
\hline Any professional experience & $\begin{array}{c}-0.013^{* * *} \\
(0.005)\end{array}$ & $\begin{array}{c}-0.017^{* * *} \\
(0.005)\end{array}$ & $\begin{array}{c}0.057^{* * *} \\
(0.018)\end{array}$ & $\begin{array}{c}-0.020^{* * *} \\
(0.008)\end{array}$ \\
\hline Labor market history & & & & \\
\hline Share of jobs involve commuting in last 5 years & $\begin{array}{c}0.017^{* * *} \\
(0.005)\end{array}$ & $\begin{array}{c}0.028^{* * *} \\
(0.004)\end{array}$ & $\begin{array}{c}-0.083^{* * *} \\
(0.016)\end{array}$ & $\begin{array}{l}-0.001 \\
(0.007)\end{array}$ \\
\hline Previous participation in mobility program & $\begin{array}{c}-0.028^{* * *} \\
(0.008)\end{array}$ & $\begin{array}{c}-0.013^{*} \\
(0.007)\end{array}$ & $\begin{array}{c}0.019 \\
(0.038)\end{array}$ & $\begin{array}{l}-0.011 \\
(0.013)\end{array}$ \\
\hline \multicolumn{5}{|c|}{ Last contact to employment agency (Ref.: more than 3 months ago) } \\
\hline 2-3 months ago & $\begin{array}{c}0.013 \\
(0.019)\end{array}$ & $\begin{array}{c}0.007 \\
(0.021)\end{array}$ & $\begin{array}{l}-0.014 \\
(0.067)\end{array}$ & $\begin{array}{c}0.026 \\
(0.029)\end{array}$ \\
\hline 1-2 months ago & $\begin{array}{c}0.022 \\
(0.020)\end{array}$ & $\begin{array}{c}0.010 \\
(0.019)\end{array}$ & $\begin{array}{l}-0.001 \\
(0.063)\end{array}$ & $\begin{array}{c}0.029 \\
(0.028)\end{array}$ \\
\hline within last month & $\begin{array}{l}-0.000 \\
(0.018)\end{array}$ & $\begin{array}{l}-0.004 \\
(0.018)\end{array}$ & $\begin{array}{c}0.044 \\
(0.060)\end{array}$ & $\begin{array}{c}0.020 \\
(0.025)\end{array}$ \\
\hline no previous contact & $\begin{array}{c}0.026 \\
(0.018)\end{array}$ & $\begin{array}{c}0.026 \\
(0.017)\end{array}$ & $\begin{array}{c}0.022 \\
(0.063)\end{array}$ & $\begin{array}{c}0.022 \\
(0.026)\end{array}$ \\
\hline \multicolumn{5}{|c|}{ Occupational group of previous job (Ref.: Agriculture) } \\
\hline Manufacturing & $\begin{array}{c}0.018^{* * *} \\
(0.006)\end{array}$ & $\begin{array}{c}0.029^{* * *} \\
(0.006)\end{array}$ & $\begin{array}{c}-0.242^{* * *} \\
(0.039)\end{array}$ & $\begin{array}{c}0.061^{* * *} \\
(0.013)\end{array}$ \\
\hline Technical occupation & $\begin{array}{c}0.035^{* * *} \\
(0.012)\end{array}$ & $\begin{array}{c}0.061^{* * *} \\
(0.011)\end{array}$ & $\begin{array}{c}-0.274^{* * *} \\
(0.046)\end{array}$ & $\begin{array}{c}0.085^{* * *} \\
(0.016)\end{array}$ \\
\hline Service & $\begin{array}{c}0.019^{* * *} \\
(0.007)\end{array}$ & $\begin{array}{c}0.036^{* * *} \\
(0.007)\end{array}$ & $\begin{array}{c}-0.246^{* * *} \\
(0.038)\end{array}$ & $\begin{array}{c}0.066^{* * *} \\
(0.014)\end{array}$ \\
\hline Other & $\begin{array}{l}-0.009 \\
(0.021)\end{array}$ & $\begin{array}{c}0.027 \\
(0.021)\end{array}$ & $\begin{array}{c}-0.213^{* *} \\
(0.085)\end{array}$ & $\begin{array}{c}0.061 \\
(0.038)\end{array}$ \\
\hline
\end{tabular}

Continued on next page. 
Continued from previous page.

\begin{tabular}{|c|c|c|c|c|}
\hline Last job was full-time employment & $\begin{array}{c}0.053^{* * *} \\
(0.016)\end{array}$ & $\begin{array}{c}0.041^{* *} \\
(0.018)\end{array}$ & $\begin{array}{l}-0.090 \\
(0.076)\end{array}$ & $\begin{array}{l}-0.001 \\
(0.024)\end{array}$ \\
\hline Log last daily income & $\begin{array}{c}0.162^{* * *} \\
(0.014)\end{array}$ & $\begin{array}{c}0.140^{* * *} \\
(0.014)\end{array}$ & $\begin{array}{l}-0.043 \\
(0.042)\end{array}$ & $\begin{array}{c}-0.002 \\
(0.017)\end{array}$ \\
\hline Reason for termination of last job: Laid off by employer & $\begin{array}{c}-0.046^{* * *} \\
(0.008)\end{array}$ & $\begin{array}{c}-0.031^{* * *} \\
(0.007)\end{array}$ & $\begin{array}{c}-0.077^{* * *} \\
(0.025)\end{array}$ & $\begin{array}{c}0.034^{* * *} \\
(0.012)\end{array}$ \\
\hline \multicolumn{5}{|l|}{ Months in employment in year } \\
\hline $\mathrm{t}-1$ & $\begin{array}{c}0.003^{* * *} \\
(0.001)\end{array}$ & $\begin{array}{c}0.002^{* * *} \\
(0.001)\end{array}$ & $\begin{array}{c}-0.045^{* * *} \\
(0.003)\end{array}$ & $\begin{array}{c}0.014^{* * *} \\
(0.001)\end{array}$ \\
\hline $\mathrm{t}-2$ & $\begin{array}{l}-0.001 \\
(0.001)\end{array}$ & $\begin{array}{r}-0.000 \\
(0.001)\end{array}$ & $\begin{array}{l}-0.004 \\
(0.003)\end{array}$ & $\begin{array}{c}0.004^{* * *} \\
(0.001)\end{array}$ \\
\hline $\mathrm{t}-3$ & $\begin{array}{c}-0.002^{* *} \\
(0.001)\end{array}$ & $\begin{array}{c}-0.001^{* *} \\
(0.001)\end{array}$ & $\begin{array}{c}-0.017^{* * *} \\
(0.003)\end{array}$ & $\begin{array}{c}0.003^{* * *} \\
(0.001)\end{array}$ \\
\hline \multicolumn{5}{|l|}{ Months in program in year } \\
\hline $\mathrm{t}-1$ & $\begin{array}{c}0.001 \\
(0.003)\end{array}$ & $\begin{array}{c}0.004 \\
(0.003)\end{array}$ & $\begin{array}{c}-0.055^{* * *} \\
(0.011)\end{array}$ & $\begin{array}{l}0.010^{*} \\
(0.005)\end{array}$ \\
\hline $\mathrm{t}-2$ & $\begin{array}{c}0.002 \\
(0.002)\end{array}$ & $\begin{array}{c}0.002 \\
(0.002)\end{array}$ & $\begin{array}{l}-0.009 \\
(0.007)\end{array}$ & $\begin{array}{l}0.005^{*} \\
(0.003)\end{array}$ \\
\hline $\mathrm{t}-3$ & $\begin{array}{l}-0.001 \\
(0.001)\end{array}$ & $\begin{array}{l}-0.000 \\
(0.001)\end{array}$ & $\begin{array}{c}-0.002 \\
(0.006)\end{array}$ & $\begin{array}{c}0.001 \\
(0.003)\end{array}$ \\
\hline \multicolumn{5}{|l|}{ Months in unemployment in year } \\
\hline $\mathrm{t}-1$ & $\begin{array}{l}-0.005 \\
(0.004)\end{array}$ & $\begin{array}{l}-0.002 \\
(0.003)\end{array}$ & $\begin{array}{l}-0.016 \\
(0.014)\end{array}$ & $\begin{array}{l}-0.003 \\
(0.006)\end{array}$ \\
\hline $\mathrm{t}-2$ & $\begin{array}{c}0.002 \\
(0.002)\end{array}$ & $\begin{array}{c}0.002 \\
(0.002)\end{array}$ & $\begin{array}{c}-0.015^{*} \\
(0.008)\end{array}$ & $\begin{array}{c}0.007^{* *} \\
(0.003)\end{array}$ \\
\hline $\mathrm{t}-3$ & $\begin{array}{l}-0.001 \\
(0.002)\end{array}$ & $\begin{array}{l}-0.000 \\
(0.002)\end{array}$ & $\begin{array}{l}0.002 \\
(0.007)\end{array}$ & $\begin{array}{c}0.000 \\
(0.003)\end{array}$ \\
\hline \multicolumn{5}{|l|}{ Log average daily wage in year } \\
\hline $\mathrm{t}-1$ & $\begin{array}{c}0.353^{* * *} \\
(0.022)\end{array}$ & $\begin{array}{c}0.346^{* * *} \\
(0.020)\end{array}$ & $\begin{array}{c}-0.082^{*} \\
(0.047)\end{array}$ & $\begin{array}{c}0.041^{* *} \\
(0.021)\end{array}$ \\
\hline $\mathrm{t}-2$ & $\begin{array}{c}0.003^{* * *} \\
(0.001)\end{array}$ & $\begin{array}{l}0.001^{*} \\
(0.001)\end{array}$ & $\begin{array}{c}0.002 \\
(0.004)\end{array}$ & $\begin{array}{l}-0.002 \\
(0.001)\end{array}$ \\
\hline $\mathrm{t}-3$ & $\begin{array}{c}0.002^{* * *} \\
(0.001)\end{array}$ & $\begin{array}{c}0.002^{* *} \\
(0.001)\end{array}$ & $\begin{array}{c}0.017^{* * *} \\
(0.003)\end{array}$ & $\begin{array}{l}-0.000 \\
(0.001)\end{array}$ \\
\hline No. of employers in last 24 months & $\begin{array}{l}-0.002 \\
(0.002)\end{array}$ & $\begin{array}{c}0.002 \\
(0.002)\end{array}$ & $\begin{array}{c}0.034^{* * *} \\
(0.009)\end{array}$ & $\begin{array}{c}0.009^{* *} \\
(0.004)\end{array}$ \\
\hline No. of programs in last 4 years & $\begin{array}{l}0.008^{*} \\
(0.004)\end{array}$ & $\begin{array}{c}0.004 \\
(0.004)\end{array}$ & $\begin{array}{l}-0.003 \\
(0.018)\end{array}$ & $\begin{array}{c}0.000 \\
(0.007)\end{array}$ \\
\hline Months in program in last 4 years & $\begin{array}{c}-0.022^{* * *} \\
(0.008)\end{array}$ & $\begin{array}{l}-0.007 \\
(0.008)\end{array}$ & $\begin{array}{l}-0.002 \\
(0.030)\end{array}$ & $\begin{array}{l}-0.006 \\
(0.014)\end{array}$ \\
\hline Time spend in unemployment in last 4 years (in 100 days) & $\begin{array}{c}0.000 \\
(0.001)\end{array}$ & $\begin{array}{l}-0.000 \\
(0.001)\end{array}$ & $\begin{array}{c}0.009^{* * *} \\
(0.003)\end{array}$ & $\begin{array}{l}-0.002 \\
(0.002)\end{array}$ \\
\hline Time spend in employment in last 4 years (in 100 days) & $\begin{array}{c}0.001 \\
(0.001)\end{array}$ & $\begin{array}{l}-0.000 \\
(0.001)\end{array}$ & $\begin{array}{c}0.004 \\
(0.003)\end{array}$ & $\begin{array}{c}-0.002^{* *} \\
(0.001)\end{array}$ \\
\hline Employed 4 years before entry into unemployment & $\begin{array}{c}-0.090^{* * *} \\
(0.008)\end{array}$ & $\begin{array}{c}-0.092^{* * *} \\
(0.008)\end{array}$ & $\begin{array}{l}-0.002 \\
(0.027)\end{array}$ & $\begin{array}{l}0.019^{*} \\
(0.011)\end{array}$ \\
\hline Daily income 4 years before entry into unemployment & $\begin{array}{c}0.001^{* * *} \\
(0.000)\end{array}$ & $\begin{array}{c}0.001^{* * *} \\
(0.000)\end{array}$ & $\begin{array}{c}-0.002^{* * *} \\
(0.000)\end{array}$ & $\begin{array}{c}0.000^{* *} \\
(0.000)\end{array}$ \\
\hline Total income in last 4 years (in $€ 10,000$ ) & $\begin{array}{c}0.001 \\
(0.002)\end{array}$ & $\begin{array}{c}0.001 \\
(0.001)\end{array}$ & $\begin{array}{l}-0.003 \\
(0.004)\end{array}$ & $\begin{array}{l}-0.001 \\
(0.002)\end{array}$ \\
\hline No. of employers in last 10 years & $\begin{array}{c}-0.003^{* * *} \\
(0.001)\end{array}$ & $\begin{array}{c}-0.003^{* * *} \\
(0.001)\end{array}$ & $\begin{array}{c}0.012^{* * *} \\
(0.005)\end{array}$ & $\begin{array}{l}-0.001 \\
(0.002)\end{array}$ \\
\hline No. of programs in last 10 years & $\begin{array}{c}-0.007^{* *} \\
(0.003)\end{array}$ & $\begin{array}{c}-0.008^{* * *} \\
(0.003)\end{array}$ & $\begin{array}{l}-0.015 \\
(0.013)\end{array}$ & $\begin{array}{l}-0.001 \\
(0.005)\end{array}$ \\
\hline Months in program in last 10 years & $\begin{array}{l}-0.005 \\
(0.007)\end{array}$ & $\begin{array}{l}-0.004 \\
(0.006)\end{array}$ & $\begin{array}{l}-0.042 \\
(0.028)\end{array}$ & $\begin{array}{c}0.030^{* * *} \\
(0.011)\end{array}$ \\
\hline Months in unemployment in last 10 years & $\begin{array}{l}-0.000 \\
(0.000)\end{array}$ & $\begin{array}{l}-0.000 \\
(0.000)\end{array}$ & $\begin{array}{l}-0.000 \\
(0.000)\end{array}$ & $\begin{array}{c}0.000 \\
(0.000)\end{array}$ \\
\hline Time spend in employment in last 10 years (in 100 days) & $\begin{array}{c}-0.002^{* * *} \\
(0.000)\end{array}$ & $\begin{array}{c}-0.001^{* * *} \\
(0.000)\end{array}$ & $\begin{array}{l}-0.001 \\
(0.001)\end{array}$ & $\begin{array}{c}0.001^{* * *} \\
(0.000)\end{array}$ \\
\hline No. of unemployment spells in last 10 years & $\begin{array}{c}0.007^{* * *} \\
(0.001)\end{array}$ & $\begin{array}{c}0.004^{* * *} \\
(0.001)\end{array}$ & $\begin{array}{c}0.060^{* * *} \\
(0.004)\end{array}$ & $\begin{array}{c}-0.012^{* * *} \\
(0.001)\end{array}$ \\
\hline Total time with last employer in last 10 years & $\begin{array}{c}0.000 \\
(0.000)\end{array}$ & $\begin{array}{c}0.000 \\
(0.000)\end{array}$ & $\begin{array}{l}-0.000 \\
(0.000)\end{array}$ & $\begin{array}{l}-0.000 \\
(0.000)\end{array}$ \\
\hline Total income in last 10 years (in $€ 10,000$ ) & $\begin{array}{l}0.002^{*} \\
(0.001)\end{array}$ & $\begin{array}{l}0.002^{*} \\
(0.001)\end{array}$ & $\begin{array}{c}0.002 \\
(0.002)\end{array}$ & $\begin{array}{l}-0.001 \\
(0.001)\end{array}$ \\
\hline Duration of last employment & $\begin{array}{c}-0.002^{* * *} \\
(0.001)\end{array}$ & $\begin{array}{c}-0.002^{* * *} \\
(0.001)\end{array}$ & $\begin{array}{l}-0.001 \\
(0.002)\end{array}$ & $\begin{array}{c}0.000 \\
(0.001)\end{array}$ \\
\hline
\end{tabular}


Continued from previous page.

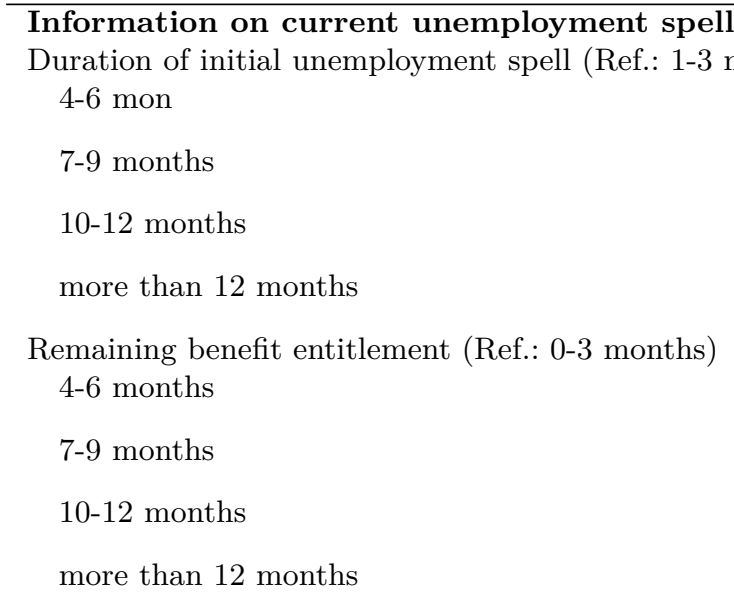

Any form of non-compliance with benefit conditions

Month of entry into unemployment (Ref.: Jan.-Mar.) Apr.-Jun.

Jul.-Sep.

Oct.-Dec.

Any vacancy referral

Participation in other ALMP program

\section{Regional characteristics}

Living in East-Germany

Local unemployment rate

GDP per capita in $€ 10000$

Local vacancy rate

Share of working population in (Ref.: Agriculture)

Industry sector

Service sector

LEA fixed effects

Number of observations

F-statistic for weak identification
Daily unemployment benefits (in €100)

Year of entry $(=2006)$

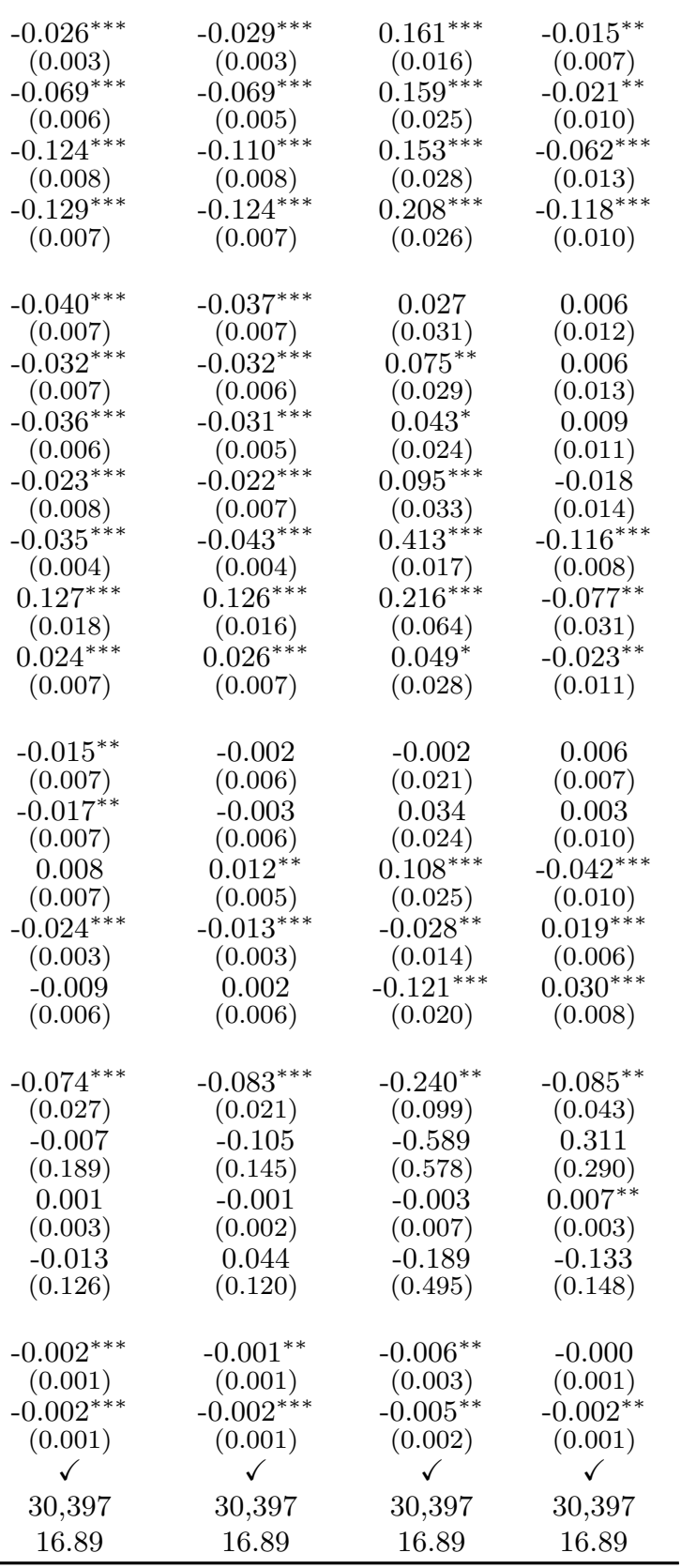

Note: 2 -SLS estimation of the outcome equation including LEA fixed effects. ***/**/* indicate statistically significance at the $1 \% / 5 \% / 10 \%$-level. Standard errors are in parenthesis and clustered ad LEA-level. 
Table B.5: Sensitivity Analysis: Alternative Employment Definition

\begin{tabular}{|c|c|c|c|c|}
\hline & $\begin{array}{l}\text { Mean non- } \\
\text { participants }\end{array}$ & $\begin{array}{l}\text { OLS } \\
(1)\end{array}$ & $\begin{array}{l}\text { IV } \\
(2)\end{array}$ & $\begin{array}{l}\text { IV } \\
(3)\end{array}$ \\
\hline \multicolumn{5}{|l|}{ A) Baseline Results } \\
\hline Log first daily wage in $t_{u e+1}$ & 66.35 & $\begin{array}{c}0.129^{* * *} \\
(0.016)\end{array}$ & $\begin{array}{c}0.504^{* * *} \\
(0.116)\end{array}$ & $\begin{array}{c}0.262^{* * *} \\
(0.081)\end{array}$ \\
\hline Log average daily wage from $t_{u e+1}$ to $t_{u e+24}$ & 68.64 & $\begin{array}{c}0.139^{* * *} \\
(0.015)\end{array}$ & $\begin{array}{c}0.395^{* * *} \\
(0.106)\end{array}$ & $\begin{array}{c}0.192^{* * *} \\
(0.069)\end{array}$ \\
\hline No. of job quits from $t_{u e+1}$ to $t_{u e+24}$ & 0.926 & $\begin{array}{c}-0.127^{* * *} \\
(0.038)\end{array}$ & $\begin{array}{c}-0.854^{* * *} \\
(0.316)\end{array}$ & $\begin{array}{c}-0.936^{* * *} \\
(0.296)\end{array}$ \\
\hline Employed in $t_{u e+24}$ & 0.710 & $\begin{array}{c}0.019 \\
(0.020)\end{array}$ & $\begin{array}{c}0.359^{* * *} \\
(0.126)\end{array}$ & $\begin{array}{c}0.259^{* *} \\
(0.102)\end{array}$ \\
\hline
\end{tabular}

B) Better Economic Conditions or Upward Job Mobility?

Relative rank of first daily wage in $t_{u e+1}$ within the overall wage distribution

$\begin{array}{lcccc}\text { within LEA district } & 0.501 & 0.061^{* * *} & 0.375^{* * *} & 0.209^{* * *} \\ \text { within LEA district and sector } & & (0.011) & (0.078) & (0.056) \\ & 0.513 & 0.059^{* * *} & 0.266^{* * *} & 0.115^{* *} \\ & & (0.011) & (0.074) & (0.056)\end{array}$

Control variables

Socio-demographic characteristics

Labor market history

Regional information

Information on current unemployment spell

LEA fixed effects

No. of observations

$\begin{array}{ll}\checkmark & \checkmark \\ \checkmark & \checkmark \\ \checkmark & \checkmark \\ \checkmark & \checkmark\end{array}$

F-statistic for weak identification

Note: Depicted are causal treatment effects using OLS and 2-SLS estimation. All estimations include several control variables for socio-demographic characteristics, short- and long-term labor market history, benefit entitlement, local macroeconomic conditions at entry into unemployment and the initial unemployment duration. */**/*** indicate statistically significance at the $10 \% / 5 \% / 1 \%$-level. Standard errors are in parenthesis and clustered at the LEA level. 
Table B.6: Selected Descriptive Statistics: Baseline vs. Extended Sample

\begin{tabular}{|c|c|c|c|c|c|c|}
\hline & \multicolumn{3}{|c|}{ Baseline estimation sample } & \multicolumn{3}{|c|}{ Extended estimation sample } \\
\hline & Participants & $\begin{array}{c}\text { Non- } \\
\text { participants }\end{array}$ & p-value & Participants & $\begin{array}{c}\text { Non- } \\
\text { participants }\end{array}$ & p-value \\
\hline No. of observations & 538 & 29,859 & & 562 & 43,242 & \\
\hline \multicolumn{7}{|l|}{ Outcome variables } \\
\hline \multicolumn{7}{|l|}{ Employed } \\
\hline in $t_{24}$ & 0.81 & 0.81 & 0.99 & 0.78 & 0.61 & 0.00 \\
\hline in $t_{48}$ & 0.75 & 0.73 & 0.23 & 0.75 & 0.59 & 0.00 \\
\hline \multicolumn{7}{|l|}{ Months in employment } \\
\hline from $t_{0}$ to $t_{24}$ & 15.26 & 15.89 & 0.02 & 14.64 & 11.57 & 0.00 \\
\hline from $t_{0}$ to $t_{48}$ & 33.68 & 33.90 & 0.67 & 32.90 & 25.75 & 0.00 \\
\hline \multicolumn{7}{|l|}{ Total income in $€ 1,000$} \\
\hline from $t_{0}$ to $t_{24}$ & 37.93 & 31.15 & 0.00 & 36.36 & 22.53 & 0.00 \\
\hline from $t_{0}$ to $t_{48}$ & 87.19 & 68.47 & 0.00 & 84.92 & 51.52 & 0.00 \\
\hline \multicolumn{7}{|l|}{ Regional information } \\
\hline Local unemployment rate & 0.14 & 0.13 & 0.00 & 0.14 & 0.13 & 0.00 \\
\hline Local vacancy rate & 0.05 & 0.06 & 0.00 & 0.05 & 0.06 & 0.00 \\
\hline Living in East-Germany & 0.49 & 0.31 & 0.00 & 0.48 & 0.29 & 0.00 \\
\hline Share of working population in industry sector & 0.20 & 0.22 & 0.00 & 0.20 & 0.22 & 0.00 \\
\hline GDP per capita in $€ 1,000$ & 24.77 & 25.95 & 0.01 & 24.96 & 26.79 & 0.00 \\
\hline \multicolumn{7}{|l|}{ Socio-demographic characteristics } \\
\hline Age in years & 37.71 & 38.54 & 0.02 & 37.78 & 38.73 & 0.01 \\
\hline (Spec.) Upper sec. degree & 0.39 & 0.14 & 0.00 & 0.39 & 0.17 & 0.00 \\
\hline University degree & 0.28 & 0.07 & 0.00 & 0.28 & 0.09 & 0.00 \\
\hline Children & 0.33 & 0.40 & 0.00 & 0.33 & 0.38 & 0.02 \\
\hline Married & 0.49 & 0.58 & 0.00 & 0.49 & 0.56 & 0.00 \\
\hline Migration background & 0.25 & 0.22 & 0.10 & 0.25 & 0.23 & 0.12 \\
\hline \multicolumn{7}{|l|}{ Labor market history } \\
\hline Last daily income in $€$ & 74.33 & 67.20 & 0.00 & 74.31 & 68.06 & 0.00 \\
\hline \multicolumn{7}{|l|}{ Occupational group of previous job } \\
\hline Manufacturing & 0.36 & 0.57 & 0.00 & 0.36 & 0.53 & 0.00 \\
\hline Technical occupation & 0.09 & 0.04 & 0.00 & 0.10 & 0.04 & 0.00 \\
\hline Services & 0.52 & 0.33 & 0.00 & 0.52 & 0.38 & 0.00 \\
\hline Time spend in unemployment in last 10 years in days & 360 & 480 & 0.00 & 362 & 488 & 0.00 \\
\hline Total gross income in last 10 years in $€ 1,000$ & 167 & 187 & 0.02 & 167 & 192 & 0.01 \\
\hline Daily amount of unemployment benefits in $€$ & 22.54 & 19.09 & 0.00 & 22.35 & 18.71 & 0.00 \\
\hline Share of jobs involve commuting in last 5 years & 0.45 & 0.29 & 0.00 & 0.45 & 0.30 & 0.00 \\
\hline Previous participation in mobility programs & 0.25 & 0.06 & 0.00 & 0.25 & 0.05 & 0.00 \\
\hline
\end{tabular}

Note: All numbers are percentages unless otherwise indicated. Regional information, socio-demographic characteristics and labor market histories are measured at entry into unemployment $\left(t_{0}\right)$. P-values are based on a two-tailed t-test on equal means between participants and non-participants. 
Table B.7: Estimation Results: Baseline vs. Extended Sample

\begin{tabular}{|c|c|c|c|c|c|c|c|c|}
\hline & \multicolumn{4}{|c|}{ Baseline sample } & \multicolumn{4}{|c|}{ Extended sample } \\
\hline & $\begin{array}{l}\text { Mean non- } \\
\text { participants }\end{array}$ & $\begin{array}{l}\text { OLS } \\
(1)\end{array}$ & $\begin{array}{l}\text { IV } \\
(2)\end{array}$ & $\begin{array}{l}\text { IV } \\
(3)\end{array}$ & $\begin{array}{l}\text { Mean non- } \\
\text { participants }\end{array}$ & $\begin{array}{l}\text { OLS } \\
(4)\end{array}$ & $\begin{array}{l}\text { IV } \\
(5)\end{array}$ & $\begin{array}{l}\text { IV } \\
(6)\end{array}$ \\
\hline \multicolumn{9}{|l|}{ Employed } \\
\hline in $t_{24}$ & 0.814 & $\begin{array}{l}-0.006 \\
(0.017)\end{array}$ & $\begin{array}{c}0.368^{* * *} \\
(0.118)\end{array}$ & $\begin{array}{l}0.233^{* *} \\
(0.108)\end{array}$ & 0.611 & $\begin{array}{c}0.175^{* * *} \\
(0.020)\end{array}$ & $\begin{array}{c}0.427^{* *} \\
(0.203)\end{array}$ & $\begin{array}{c}0.254 \\
(0.155)\end{array}$ \\
\hline in $t_{48}$ & 0.731 & $\begin{array}{c}0.011 \\
(0.019)\end{array}$ & $\begin{array}{c}0.414^{* * *} \\
(0.106)\end{array}$ & $\begin{array}{l}0.241^{* * *} \\
(0.099)\end{array}$ & 0.591 & $\begin{array}{c}0.157^{* * *} \\
(0.020)\end{array}$ & $\begin{array}{c}0.327 \\
(0.249)\end{array}$ & $\begin{array}{c}0.252 \\
(0.175)\end{array}$ \\
\hline \multicolumn{9}{|l|}{ Months in employment } \\
\hline from $t_{0}$ to $t_{24}$ & 15.90 & $\begin{array}{c}-0.797^{* * *} \\
(0.249)\end{array}$ & $\begin{array}{c}5.996^{* * *} \\
(1.970)\end{array}$ & $\begin{array}{l}4.229^{* *} \\
(1.889)\end{array}$ & 11.57 & $\begin{array}{c}3.169 \\
(0.338)\end{array}$ & $\begin{array}{l}8.179^{*} \\
(4.464)\end{array}$ & $\begin{array}{l}7.857^{* *} \\
(3.329)\end{array}$ \\
\hline from $t_{0}$ to $t_{48}$ & 33.90 & $\begin{array}{c}-0.746 \\
(0.487)\end{array}$ & $\begin{array}{c}15.635^{* * *} \\
(3.630)\end{array}$ & $\begin{array}{c}10.725^{* * *} \\
(3.289)\end{array}$ & 25.75 & $\begin{array}{c}7.164 \\
(0.672)\end{array}$ & $\begin{array}{c}17.928^{* *} \\
(9.018)\end{array}$ & $\begin{array}{c}15.490^{* *} \\
(6.268)\end{array}$ \\
\hline \multicolumn{9}{|l|}{ Total income in $€ 1,000$} \\
\hline from $t_{0}$ to $t_{24}$ & 31.15 & $\begin{array}{c}2.02^{* * *} \\
(0.64)\end{array}$ & $\begin{array}{c}23.24^{* * *} \\
(7.10)\end{array}$ & $\begin{array}{l}11.82^{*} \\
(6.69)\end{array}$ & 22.53 & $\begin{array}{c}11.67^{* * *} \\
(0.80)\end{array}$ & $\begin{array}{c}37.48^{* * *} \\
(12.73)\end{array}$ & $\begin{array}{c}29.50^{* * *} \\
(9.92)\end{array}$ \\
\hline from $t_{0}$ to $t_{48}$ & 68.47 & $\begin{array}{c}7.17^{* * *} \\
(1.34)\end{array}$ & $\begin{array}{c}51.25^{* * *} \\
(14.06)\end{array}$ & $\begin{array}{l}24.90^{* *} \\
(12.77)\end{array}$ & 51.52 & $\begin{array}{c}27.44^{* * *} \\
(1.69)\end{array}$ & $\begin{array}{c}79.56^{* * *} \\
(26.24)\end{array}$ & $\begin{array}{c}58.42^{* * *} \\
(18.86)\end{array}$ \\
\hline Number of observations & & 30,397 & 30,397 & 30,397 & & 43,804 & 43,804 & 43,804 \\
\hline F-statistic for weak identification & & & 30.62 & 16.89 & & & 28.34 & 10.62 \\
\hline LEA fixed effects & & & & $\checkmark$ & & & & $\checkmark$ \\
\hline
\end{tabular}

Note: Depicted are estimated treatment effects separated for the baseline estimation sample, comprising all individuals who find a new employment within 24 months, and the extended estimation sample without this restriction. $* * * / * * / *$ indicate statistically significance at the $1 \% / 5 \% / 10 \%-l e v e l$. Standard errors are presented in parenthesis and the clustered at the LEA level. 